\title{
DISCLAIMER
}

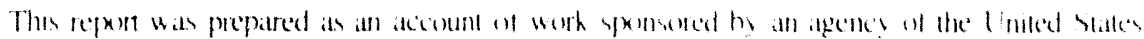

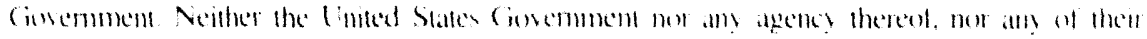

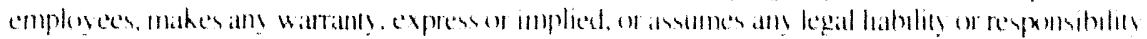

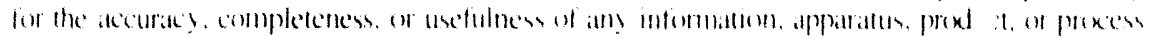

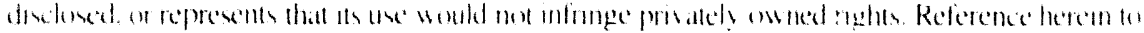

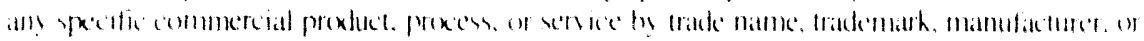

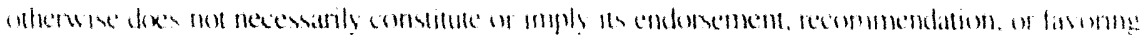

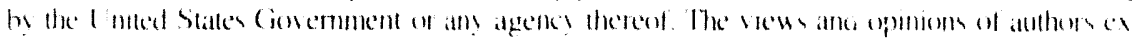

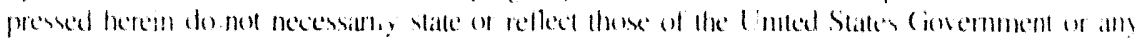
deentertheres.

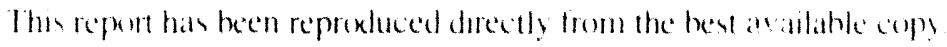

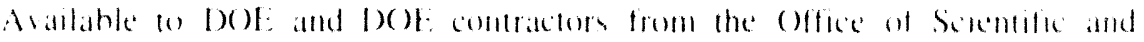

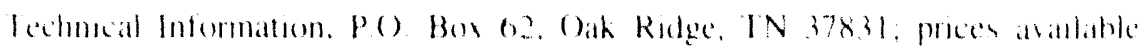
$\mid x+m+6) 5,576 \times 4+101$

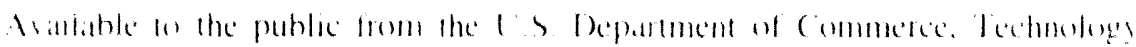

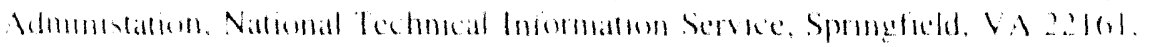

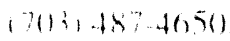




\section{PULSED COMBUSTION PROCESS FOR BLACK LIQUOR GASIFICATION}

By:

Momtaz N. Mansour

K. Durai-Swamy

Babak AghaMohammadi

SECOND ANNUAL REPORT

February, 1990

Performed Under:

Contract No. DE-FC05-90CE40893

Prepared For:

Stanley F. Sobczynski

Program Manager EE-233

Office of Industrial Programs

U.S. DEPARTMENT OF ENERGY

Conservation and Renewable Energy

Washington, D.C. 20585 


\section{EXECUTIVE SUMMARY}

This second annual report summarizes the work accomplished during the period November 1990 through February 1992 for DOE Cooperative Agreement No. DE-FC05-90CE40893. The overall project objective is to field test an energy-efficient, innovative black liquor recovery system at a significant industrial scale. This is intended to demonstrate the maturity of the technology in an industrial environment and serve as an example to the industry of the safer and more energy-efficient processing technique.

The project structure is comprised of three primary activities: process characterization testing, scale-up hardware development, and field testing. The objective of the process characterization testing was to resolve key technical issues regarding the black liquor recovery process that were identified during earlier laboratory verification tests. This was intended to provide a sound engineering data base for the design, construction and testing of a nominal 1.0 TPH integrated black liquor recovery gasifier.

The objective of the scale-up hardware development effort was to ensure that key hardware components, in particular the pulse heater module, would perform reliably and safely in the field.

Finally, the objective of the field test is to develop an industrial data base sufficient to demonstrate the capabilities and performance of the operating system with respect to thermal efficiency, product quality, fuel handling, system control, reliability and cost. These tests are to provide long-term and continuous operating data at a capacity unattainable in the bench-scale apparatus.

The design development and recommissioning of the bench-scale integrated gasification unit along with various process characterization tests conducted were reported in the first annual report. Some additional process characterization tests were performed to improve the overall process efficiency by utilizing the sensible heat of the product gas. Partial drying of the feed material utilizing the sensible heat of the product gas would improve the 
overall process efficiency. Two options were tested in the bench-scale unit for pre-drying the feed material. The first option was to inject a portion of the feed black liquor into the freeboard of the gasifier reactor. Test results indicated that a fine atomization of the black liquor feed is required to achieve any considerable drying in the freeboard due to short residence times. Fine atomization of the black liquor requires an additional high pressure pump and also increases the eiutriation of the solids from the freeboard. The second option was to compartmentalize or partition the fluidbed reactor. In this configuration the fluid bed is divided into a cooler compartment and a hot compartment. The cooler compartment is used for drying the feed black liquor and the hot compartment for gasifying the dried black liquor. A test was performed in the bench-scale unit to verify the operability of this concept. The test results indicated that additional detailed design and analysis of the feed system and individual fluidization nozzles for each compartment would be required and could add substantially to the cost and complexity of the process.

The data base gathered during the extensive Phase I bench-scale testing provided significant information essential for the design and development of a scale-up field test unit. However, it was soon realized that a $\frac{1}{2}$-scale prototype pulse tube heater unit should be developed and tested to ensure that this key hardware component would perform reliably during field service. A $5 \mathrm{MMBtu} / \mathrm{hr}$ pulsating tube heater module consisting of 61 , 1 inch dialniter, partially shielded tubes arianged in a hexayonal staggered array and spaced on 3-inch centers was fabricated. The previous annual report [1] describes most of the development and testing of this unit. The operation of the prototype $5 \mathrm{MMBtu} / \mathrm{hr}$ tube heater over a range of firing rates with low flue gas emissions at low excess air levels was successful and provided confidence in the performance at the scaled-up level.

Testing of the prototype 5 MMBtu/hr heater resulted in incorporation of the following changes in the field test unit:

- Modified gas injectors

- Water jacketed combustion chamber and tube sheet

- Five aerovalve configurations

- 72-tube heater bundle 
The prototype 61-tube heater module and its performance were evaluated only at the laboratory scale under simulated conditions during this period. It alsu became apparent that it was essential that at least one heater module be tested using real black liquor feed at conditions similar to those that wouid be required at New Bern. This would require numerous other components such as venturi and caustic scrubbers, an impact separator with heat exchanger, a cyclone, a flare, waste heat boilers, mufflers, etc. A cost and performance analysis indicated that a paper mill sludge could be used as a feed material to simulate black liquor without incurring the additional cost for the conversion of the process chemicals to green liquor. Three paper mills showed an interest in hosting the heater performance evaluation tests using their sludge waste. Of the three, namely, Smurfit Newsprint Corporation, Inland Container Corporation (ICC), and Simpson Paper Company, ICC was chosen to be the host site. A 1 -ton per hour heater evaluation pilot unit was installed at ICC's recycle paper mill site in Ontario, California. One 72 -tube heater bundle was to be used to gasify 1 -ton per hour wet sludge with moisture content ranging from 50 to 80 percent. The California Energy Commission provided financial support (cost sharing) of $\$ 500 \mathrm{~K}$ for the pilot and tests and ICC provided a site and utilities as well as feed.

A 72-tnbe pulse heater bundle module consisting of a water-jacketed refiactory-lined cylindrical combustion chamber was designed and fabricated. Several laboratory test runs were conducted to obtain and study the characteristics of the 72-tube heater module. The heater module was successfully operated over a wide range of firing rates $(1.9$ to $7.4 \mathrm{MMBt} / \mathrm{hr}$ ) with a maximum peak-to-peak pressure of $2.6 \mathrm{psi}$ and a design operating frequency of $60 \mathrm{~Hz}$. Due tu rolatively high noise levels during the operation of the 72 -tube heater bundle, it was decided to design mufflers for the inlet and exhaust ports of the heater. A two-stage milufler was designed and fabricated for both inlet and exhaust. plenum which resulted in a 15 to $20 \mathrm{~dB}$ noise level reduction at both the inlet and the exhaust plenums. The entis,ions fran the 7 ? tube heatel bundle were, as expected, very low with NOx enissions between 27 and 40 ppm at $3 \% 0_{2}, C 0$, combustible emissions were undetectable. 
After acquiring the required permits and insurance, the installation of the pilot unit for the heater assembly at Inland container corporation was initiated and completed in four munths. The host company recycles corrugated boxes and currently has a non-hazardous sludye waste product consisting of cellulose paper fibers that are too small to be used in making newsprint. The mill disposes of 50 tons per day of this fibrous sludge waste in a nearby landfill at considerable expense to the mil1. Because the MTCI process was also designed to process a wide spectrum of energy-bearing waste and biomass in an environmentally and economically sound manner, the pilot test provided much valuable information on the system behavior and characteristics. Additionally, the pilot unit would establish the industrial scale operability of the MTCI pulse heater.

As of the preparation of this Annual Report, the pulse heaters have successfully completed all shakedown tests as well as a 500 -hour continuous test completed during the month of July but not discussed in this report. 


\section{ACKNOWLEDGMENT}

The authors wish to acknowledge the help and support received from the U.S. Department of Energy, Technical Project Manager, Stanley F. Sobczynski; Denny Hunter and Craig Brown of Weyerhaeuser Paper Company; Prabjot Sethi of the California Energy Commission for their support of the heater evaluation test and Rick Dauber and Mike Sullivan of the Inland Container Corporation whose support for the test at their site was a significantly valuable contribution to the project. 


\section{TABLE OF CONTENTS}

Page

EXECUTIVE SUMMARY ......................... . . . i

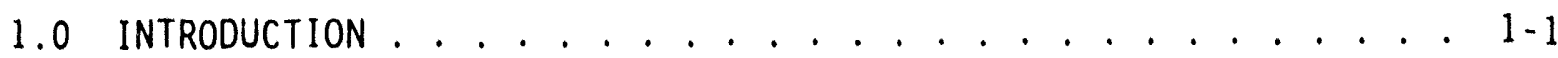

2.0 PROJECT OBJECTIVES . . . . . . . . . . . . . . . . . . . . . . 2 . 1

3.0 WORK TASK DESCRIPTION .......................... 3 . . .

3.1 PHASE I - PROCESS DESIGN VERIFICATION . . . . . . . . 3-1

3.1.1 Task 1.1: Gasification Recommissioning ..... 3-1

3.1.2 Task 1.2: Process Design Verification Tests... 3-2

3.1.3 Task 1.3: Data Reduction and Analysis...... 3-3

3.1.4 Task 1.4: Engineering Design . . . . . . . . . . 3-3

3.2 PHASE II - FIELD UNIT DESIGN, CONSTRUCTION

(SHAKEDOWN AND TEST) ............... . . 3-4

3.2.1 Task 11.1: Establish Performance and Controls Development . . . . . . . . . 3-4

3.2.2 Task II.2: System Design . . . . . . . . . . 3-5

3.2.3 Task II.3: Test Plan ............. 3-5

3.2.4 Task II.4: Final Design .. . . . . . . . . . . 3-6

3.2.5 Task II.5: Equipment Procurement, Construction and Installation .. . . . . . 3-6

3.2.6 Task 11.6: Shakedown Testing 1.0 TPH Black Liquor Recovery Units . . . . . . 3-6

3.2.7 Task 11.7: Management and Reporting. . . . . . . 3-6

3.2.8 Task 11.8: Move and Install Gasifier In Pulp Mill Site . . . . . . . . . . . . . 3-7

3.2.9 Task II.9: Field Tests . . . . . . . . . . 3-7

3.2.10 Task 11.10: Remove Field Test Unit and Restore Host Site.......... . 3-7

4.0 ADDITIONAL BENCH-SCALE TESTS . . . . . . . . . . . . . . . 4-1

4.1 FREEBOARD DRYING TEST .................... 4-.

4.2 COMPARTMENTALIZED DRYING TEST . . . . . . . . . . . . . 4-4 


\section{TABLE OF CONTENTS \\ (CONT'D)}

Page

5.0 DEVELOPMENT AND TESTING OF A PROTOTYPE

61 -TUBE COMBUSTOR HEATER MODULE .............. 5-1

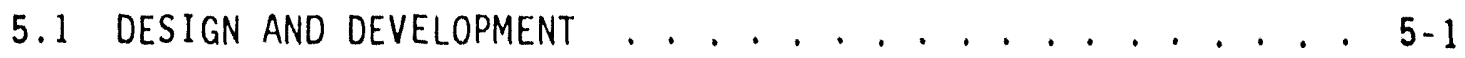

5.2 TESTING . . . . . . . . . . . . . . . . . . . $5-4$

5.3 SOME MAJOR DESIGN PARAMETERS/CHANGES OBTAINED
OR INCORPORATED DURING THE PROTOTYPE TESTING . . . . . . 5-10

5.4 COMPARTMENTALIZED GASIFIER TESTING . . . . . . . 5-13

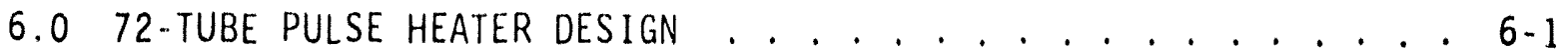

6.1 DEVELOPMENT BACKGROUND .............. 6-1

6.272 -TUbe PULSE HEATER BUNDLE MOdULE . . . . . . . 6-2

6.3 LABORATORY TESTING OF THE HEATER MODULE . . . . . . . 6-6

6.4 TEST RESULTS .................. . . . . . . . . .

7.0 PERFORMANCE EVALUATION TEST OF A 72-TUBE PULSE

HEATER UNDER BLACK LIQUOR SIMULATED CONDITIONS . . . . . . 7-1

7.1 PROCESS DESCRIPTION .............. . . . . . .

7.1.1 The Gasification Process .......... 7-2

7.1.2 Pulse Combustion Heater System ...... 7-5

7.1.3 Fluidizing Media Circuit . . . . . . . . . 7-5

7.1.4 Venturi Scrubber System . . . . . . . . . 7-5

7.1 .5 Caustic-Scrubber Circuit . . . . . . . . 7-6

7.1.6 Cooling Water Cycle ............ . 7-6

7.2 POSSIBLE POINT SOURCES OF EMISSIONS . . . . . . 7-6 


\section{TABLE OF CONTENTS \\ (CONT'D)}

Page

7.3 PROCESS EQUIPMENT DESCRIPTION ............ . . . . .

7.3.1 The Sludge Feeder System $(X-1$ and $X-2)$. . . . . 7-7

7.3.2 The Gasifier/Reactor (R-1) . . . . . . . . . 7-8

7.3.3 Pulse Combustion Heater ............ 7-11

7.3.4 Impact Separator and Cyclone:

Solid Separations Systems .......... 7-11

7.3.5 Venturi Scrubber ............... 7-12

7.3.6 Caustic Scrubber System .. . . . . . . . . . . 7-12

7.3.7 Flue Gas Waste Heat Recovery Steam Generator. . . 7-14

7.3.8 Stack Muffler . . . . . . . . . . . . . . 7-14

7.3.9 Air Plenum Muffler.............. . 7-16

7.3.10 Data Acquisition anu Control System . . . . . . 7-16

7.4 PLANT LAYOUT AND THE CURRENT STATUS

OF THE PILOT PLANT . . . . . . . . . . . . . . . . 7-22

8.0 CONCLUSIONS AND RECOMMENDATIONS ............. 8-1

APPENDIX A: TEST PARAMETERS 


\section{LIST OF FIGURES}

Page

FIGURE 4-1 BENCH-SCALE TEST RIG................. . . 4-2

FIGURE 4-2 DRAWING OF THE GASIFIER REACTOR WITH

BLACK LIQUOR INJECTION IN FREEBOARD . . . . . . . . . 4-3

FIGURE 4-3 COMPARTMENTALIZED DRYING - REACTOR . . . . . . . . . 4-5

FIGURE 4-4 COMPARTMENTALIZED REACTOR GASIFICATION

TEST HISTORY . . . . . . . . . . . . . . . . 4-7

FIGURE 4-5 COMPARTMENTALIZED REACTOR GASIFICATION

TEMPERATURE PROFILE AT 12:00............ 4-8

FIGURE 4-6 COMPARTMENTALIZED REACTOR GASIFICATION

TEMPERATURE PROFILE AT 3:00 . . . . . . . . . . . . . 4-10

FIGURE 4-7 COMPARTMENTALIZED REACTOR - SUGGESTED

CONFIRMATION . . . . . . . . . . . . . . . . . 4-11

FIGURE 5-1 FULL-SCALE PULSE HEATER MODULE . . . . . . . . . . 5-2

FIGURE 5-2 EXPLODED VIEW OF PULSE HEATER MODULE . . . . . . . . . 5-3

FIGURE 5-3 COMBUSTOR TUBE BUNDLE INTERFACE . . . . . . . . . . . 5-5

FIGURE 5-4 EXPERIMENTAL SETUP ................. . 5-6

FIGURE 5-5 SCHEMATIC OF THE TEST SETUP . . . . . . . . . . . . . . 5-7

FIGURE 5-6 THERMOCOUPLE LOCATION (61-TUBE TEST UNIT) . . . . . . . 5-9

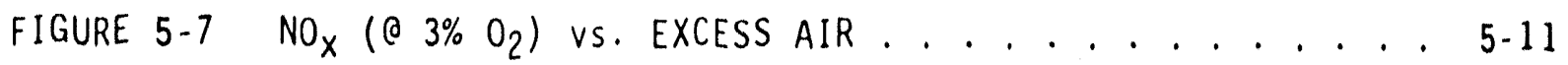

FIGURE 5-8 SCHEMATIC OF NEW GAS INJECTOR TIP OESIGN . . . . . . 5-12

FIGURE 5-9 TWO COMPARTMENT REACTOR VESSEL: TEST SETUP . . . . . . 5-17

FIGURE 5-10 THREE COMPARTMENT REACTOR VESSEL: TEST SETUP . . . . 5-18

FIGURE 6-1 HEATER MODULE FOR BLACK LIQUOR GASIFIER

(With Radiation Shield) .............. . 6-3

FIGURE 6-2 HEATER MODULE WITHOUT RADIATION SHIELD . . . . . . . . 6-4

FIGURE 6-3 72-TUBE HEATER BUNDLE ASSEMBLY . . . . . . . . . . . . 6-5 


\section{LIST OF FIGURES \\ (CONT'D)}

Page

FIGURE 6-4 72-TUBE HEATER: WATER JACKETED AND REFRACTORY-

LINED COMBUSTION CHAMBER AND TUBE SHEET . . . . . . . . 6-7

FIGURE 6-5 HEXAGONAL ARRANGEMENT OF TUBE BUNDLES . . . . . . . . . 6-8

FIGURE 6-6 PULSE HEATER AND PRESSURE TEST VESSEL . . . . . . . . . 6-9

FIGURE 6-7 SCHEMATIC OF LABORATORY TEST SETUP . . . . . . . . . . 6-10

FIGURE 6-8 EFFECT OF BOILER AND STACK MUFFLER ON

ACOUSTIC NOISE LEVEL ............... . 6-20

FIGURE 6-9 VARIATION OF NOISE LEVEL WITH FIRING RATE

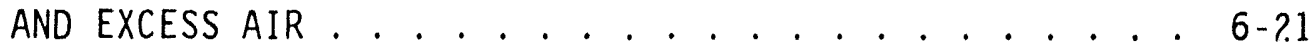

FIGURE 6-10 COMPARISON OF NOISE LEVELS FOR TWO TYPES

OF AEROVALVES ................ . . 6-22

FIGURE 6-11 REDUCTION IN NOISE LEVEL BY AIR PLENUM MUFFLER . . . . . 6-23

FIGURE 7-1 PROCESS FLOW DIAGRAM FOR THE SLUDGE

GASIFICATION PILOT PLANT . . . . . . . . . . . . . . . 7-4

FIGURE 7-2 SLUDGE FEEDER SYSTEM . . . . . . . . . . . . . . . . 7 -9

FIGURE 7-3 REACTOR/GASIFIER VESSEL . . . . . . . . . . . . . . . 7-10

FIGURE 7-4 VENTURI SCRUBBER AND COOLING SYSTEM .......... 7-13

FIGURE 7-5 $\mathrm{H}_{2} \mathrm{~S}$ SCRUBBER . . . . . . . . . . . . . . . . . . . . . . 7-15

FIGURE 7-6 STACK MUFFLER AND EXHAUST . . . . . . . . . . . . . . . $7-17$

FIGURE 7-7 AIR PLENUM MUFFLER ................. . 7-18

FIGURE 7-8 SCHEMATIC OF PILOT PLANT LAYOUT . . . . . . . . . . . 7-23

FIGURE 7-9 HEATER PERFORMANCE EVALUATION UNIT . . . . . . . . . . . . 7-24 


\section{LIST OF TABLES}

Page

TABLE 4-1 COMPARISON OF GASIFIER TEMPERATURE AT

PARTIAL TOP FEEDING AND NORMAL FEEDING . . . . . . 4-4

TABLE 5-1 COMBUSTION PERFORMANCE OF THE 61-TUBE

PULSE HEATER .................. 5-8

TABLE 5-2 COMPARISON OF 4 AND 5 AEROVALVE CASES . . . . . . . 5-14

TABLE 6-1 DATA AND RESULTS FOR 8/30/91 TEST RUN . . . . . . . 6-12

TABLE 6-2 DATA AND RESULTS FOR 9/20/31 TEST RUN . . . . . . . 6-13

TABLE $6-3$ DATA AND RESULTS FOR 12/4/91 TEST RUN . . . . . . . 6-14

TABLE 6-4 DATA AND RESULTS FOR 12/5/91 TEST RUN . . . . . . . 6-15

TABLE 6-5 COMPARISON OF NOISE LEVELS WITH TWO

DIFFERENT AEROVALVES .............. . . 6-16

TABLE 6-6 EMISSIONS DATA FROM THE 72-TUBE HEATER TESTS . . . . . 6-17

TABLE 7-1 CHEMICAL ANALYSIS OF TYPICAL SLUDGE WASTE

(From Host Paper Mil1) . . . . . . . . . . . 7-3

TABLE 7-2 LIST OF MAJOR EQUIPMENT .............. . 7-8

TABLE 7-3 CONFIGURATION SUMMARY OF TWO MCI M-200s ....... . 7-20 
SECTION 1.0

INTRODUCTION

This report summarizes the work accomplished for the development of a Pulsed Combustion Process for Black Liquor Gasification during the period from November 1990 through February 1992. Based on the extensive bench-scale experimental investigation reported in the previous annual report [1], design development and additional overall process tests were carried out for the field test unit to be tested at Weyerhaeuser's Kraft Pulp Mill in New Bern, North Carolina. Fabrication and procurement of the components for the New Bern system is still in progress.

In order to test the performance of the MTCI pulse combustion heater on a feedstock that could simulate black liquor, a pilot-scale facility was installed at the Inland Container Corporation's Recycle Paper Mill in Ontario, California. The pilot plant is currently in the testing stage and is expected to complete a 500 -hour continuous test in July 1992. This report also summarizes the development, commissioning and initial testing of this pilot plant.

The Pulsed Combustion Process for Black Liquor Recovery comprises a pulse-enhanced, indirectly heated, fluidized bed reactor using the principle of steam gasification that effectively recovers the inorganic sodium process chemicals and energy from the black liquor that also contain organic matter (lignin) from the pulping process. The integrated system results in the production of a green liquor product stream that is recycled to the pulping process as well as a high-quality medium-Btu gas that is used to supplement and/or reduce purchased fuel requirements within the mill.

The MTCI indirectly heated gasifier technology is differentiated from existing combustion-based recovery mechods by the avoidance of a sodium smelt formation that routinely results in fouling of heat exchange surfaces and corrosion of boiler components. The molten smelt also poses serious safety problems due to smelt-water explosions. Also, the gasification technology 
converts organic matter to fuel gas, as opposed to combustion-based processes which generate steam as the sole energy product. This is advantageous since the fuel gas can be combusted in a gas turbine combined cycle system providing overall higher conversion efficiencies as compared to simple steam cycles.

Finally, the Pulsed Combustion Process for Black Liquor Gasification offers the singularly unique ability to separate sulfur from sodium regardless of the chemical nature of the starting liquor. This is significant since it offers an economic and efficient means of recovering process chemicals for a broad range of spent pulping streams (Kraft through sulfite liquors). A more detailed description of the integrated gasification process and its benefits can be found in [2].

In Secti 112.0 of this report, key program objectives are highlighted. A detailed listing of project work tasks are found in Section 3.0. Section 4.0 provides a description of the additional tests performed on the bench-scale unit. Section 5.0 discusses the development and testing of a prototype 61 -tube heater. Section 6.0 presents the development and testing of the 72-tube heater in the pilot plant operating on a paper mill sludge as for sludge gasification. Section 7.0 gives an overview of the status of the field test of the 72 -tube heater, and Section 8.0 presents conclusions and recommendations for completing the project. 


\section{SECTION 2.0 \\ PROJECT OBJECTIVES}

The overall project objective is to develop an industrial data base sufficient to demonstrate the capabilities and performance of the operating system with respect to thermal efficiency, product quality, fuel handling, system control, reliability and cost. These tests are to provide long-term and continuous operating data at a capacity unattainable in the bench-scale apparatus and at a significant industrial scale. This is intended to denonstrate the maturity of the technology at a scale and in the industrial environment in which it is intended to perform.

The project structure is comprised of three primary activities: process characterization testing, scale-up hardware development, and field testing. The objective of the process characterization testing was to resolve key technical issues regarding the black liquor recovery process that were identified during prior feasibility tests conducted under several projects sponsored by the Weyerhaeuser Company as part of a California Energy Commission award and in part by the DOE, Battelle Pacific Northwest Laboratories. This was intended to provide a sound process data base for the design, construction and testing of a nominal 1.0-TPH system integrated, black liquor recovery gasifier.

The objective of the scale-up hardware development effort was to ensure that key hardware components, in particular the pulse heater module would perform reliably and safely in field tests.

Finally, the immediate objective of the field test is provide long-term and continuous operating data at a capacity and size unattainable in small units. 


\section{SECTION 3.0 \\ WORK TASK DESCRIPTION}

The following section summarizes the work task description for Phase I and Phase II activities under DOE Contract DE-FC05-90CE40893. Phase I tasks have focused on the collection of process design verification data from benchscale test equipment, and the translation of this data to the engineering design of a nominal 1.0-TPH field test unit. Phase I tasks were completed and reported in the previous annual report [1].

Phase II tasks comprise a set of activities leading to operational testing of a nominal 1.0-TPH field test gasification system. These activities include key hardware and control development, detailed plant engineering, test plan preparation, equipment procurement, construction and installation, and finally shakedown and field testing. A portion of the Phase II hardware and control development testing has been completed at the time of this report. The results of these Phase II accomplishments are discussed in Section 7.0 , "Development Testing."

A detailed description of Phase I and Phase II work tasks follows here.

\subsection{PHASE I - PROCESS DESIGN VERIFICATION}

\subsubsection{TASK I.1: GASIFIER RECOMMISSIONING}

The 8 -inch process design verification gasification system, laboratory feasibility unit, will be recommissioned. The effort will include modification of the black liquor feed subsystem, fabrication and installation of a gasifier slip-stream scrubber facility, modification of the gas analysis sampling train, and gas chromatograph to extend the range of detectable gas components to include sulfur species and upgrading of the systems controls. 


\subsubsection{TASK I.2: PROCESS DESIGN VERIFICATION TESTS}

The unit will be operated to collect critical design data that will be needed for scaling to the field-test unit.

\section{A. SUBTASK I.2.1: GAS PHASE SULFUR DISTRIBUTION}

Steady-state gasification test will be conducted to establish tine identity and quantity of sulfur-containing constituents in the product gas stream. A specialized gas chromatograph capable of differentiating a broad spectrum of sulfur species will be employed to accomplish this work. Analysis will be made to quantify the sulfur species contained in the solid products from the gasifier. An overall sulfur elemental balance will then be calculated from both solid phase and gas phase analysis.

\section{B. SUBTASK 1.2.2: SCRUBBER VERIFICATION TESTS}

A sample gas scrubber subsystem will be constructed and installed. The scrubber will be employed to verify the recovery of green 1 iquor by absorption of $\mathrm{H}_{2} \mathrm{~S}$ from a product gas slip-stream. The scrubbing solution will consist of an aqueous sodium carbonate solution that simulates the solids dissolution product from the gasifier. The $\mathrm{H}_{2} \mathrm{~S}$ concentration at the exit of the scrubber will be analyzed to obtain estimates of achievable scrubbing efficiancies. In addition, the scrubbing solution will be analyzed for relevant sulfur compounds. This subtask will provide essential information regarding the basic chemistry of the scrubbing operation, and in particular, tile nature of trace sulfur species that may be absorbed in the green liquor solution. In addition, solid samples from the gasifier will be dissolved in a tank and ils properties will be characterized. This solution, being repres ntative of the scrubbing solution to be used in the integrated field test unil, will allow meaningful analysis of the process requirements for handling this stream Particular attention will be given to the treatment and filtering of carbon from the solution.

\section{SUBTASK I.2.3: COMBUSTION OF SIMULAILD PRODUCY GAS}

Commercial gasification systems may utilize part of the product gas as the pulse combustor fuel source. In contrast, prior laboratory tests have 
(mplayed naturd gas fuels. Since the combuslion properties of the se fuels ditur, tests are necesary to verify pulse combustor operation on fuel gases with chemical compositions and anorgy densities similar to that of the product gas.

\section{SUBTASK 1.2.4: EVAIUAIION OF EFFECT OF RECYCLE GAS}

Commercial gasification systems will utilize recycle gas to assist in bed flatioution and enhance system thermal efficiency by reducing the amount of stuam to the minimum required by the gasification process. In contrast, prior laboiatury test: have been conducted without recycle gas by using steam as the sule fluidization medium. The primary difference in these cases relates to the steam partial pressure within the gasifier that impacts the gasification rate and the product yas yield distribution. Thus, a set of tests will be specifically designed to evaluate the effect of steam partial pressure on the gasifier performance.

\subsubsection{TASK I.3: DATA REDUCTION AND ANALYSIS}

The data collected during Phase I testing will be reduced and summarized. This work will include development of correlations, graphs, plots, and design equations as necessary for saling to the ficld test, complete recovery train unit

\section{3 . I.4 IASK I. 4: ENGINEERING DESIGN}

it the conclusion of the exporimental portion of Phase 1 , an engineering tesian will be prepares for the 1.0.19l field test unit. The engineering doser will be guddoty this dita ubtained from the experimental program and will inctude the following pretiminary engireming documents:

- Process Flow Miagrim

- Heat and liaterial Balance

- Plol piar

- poping liagrali

- Procoss fuipment Drawings and specificalions 
In addition, a budget estimate for the proposed field-test plant will be prepared.

\subsection{PHASE II - FIELD UNIT DESIGN, CONSTRUCTION (SHAKEDOWN AND TEST)}

\subsubsection{TASK II.1: EStablish Performance AND CONTROLS DEVELQPMENT}

Objectives for system design, performance and operation will be established. Performance and design objectives will be specified for each system and feed to be tested and will include:

- Air/fuel ratio,

- Fuel feed rate,

- Steam injection rates,

- Energy production rate (in millions of $B t u / h r$ ) to be achieved at a specific air/fuel ratio, fuel feed rate, and steam injection rate,

- Producer gas production rate and energy content (Btu per standard cubic foot),

- The concentration $\left(p p m_{v}\right)$ and distribution of low to high molecular weight hydrocarbons in the producer gas,

- Producer gas particulate matter concentration and size distribution, and

- Char or ash production rate.

A single module heater bundle of the size that will be used in the rieldtest unit will be constructed, tested and evaluated. This shall consist of multiple resonance tubes of about sixty. The mechanical design criteria with respect to the differential thermal expansion of the tubes, relationship between tube packing pattern, fluidizing velocity and heat transfer from tubes to the bed, and pulse burner safety controls will be established. 
An overall control scheme for the process will be established and a control system will be constructed and tested at the laboratory scale. In the single module heater test rig, sand of different size ranges shall be used for achieving different bed conditions; air shall be employed as fluidizing medium and water shall be used (in place of black liquor) for heat load. Hot operating conditions that are expected in the field-test units between $1100^{\circ} \mathrm{F}$ to $1200^{\circ} \mathrm{F}$ shall be established and controlled using the firing rate of the pulse combustor and the feed liquor (water) rate. The control protocol shall be established from these tests for the field-test unit.

\subsubsection{IASK II.2: SYSTEM DESIGN}

During Phase 11, designs will be prepared for the 1.0.TPH black liquor recovery gasifier. The design will include mass and energy balances for the systein. In addition, chemical kinetic calculations, subsystem performance sensitivity analysis, environmental impact analysis, safety analysis, and critical materials analysis will be conducted for the overall system and each of the following subsystems:

- System instrumentation and control,

- Fuel feed system,

- Air and stream injection systems.

- Pulse combustor.

- Ash and/or char handling system, and

- Air pollution control system.

\subsubsection{TASK II.3: TEST PLAN}

A test plan for system testing and evaluation will be evaluated. The plan will describe overall objectives of each major phase of testing, and for each of the subsystems. It will include performance testing over the full operational range of the system. The plan will include a description of each fuel to be tested, each test performed, a protocol for conducting the test, equipment necessary, and data to be obtained. 


\subsubsection{TASK II.4: FINAL DESIGN}

Based on the work completed in Phase 1 and phase 11 , a set of final designs will be developed including materials selection, for the combusto: and other support subsystems. A set of working final de igns of the system will be prepared that will include the following:

- Blueprints or detailed drawings of the overall system,

- Individual blueprints and materials specifications for each of the major subsystems, and

- Estimated bills of materials for all major subsystems.

\subsubsection{TASK II. 5: EOUIPMENT PROCUREMENT, CONSTRUCTION AND INSTALLATION}

During Phase 11, a modular 1.0. IPH inteyrated black liquor recovery plant will be constructed. The unit will be skid muunted in transportable pallets for shipment to the mill test site. It will be interfaced in the mill as required. Documentation showing all required local, state, and federal permits, if any, will be obtained for the project.

The gasifier hot section with necessary a yolles and venturi scrubber shall be in one group of skids and the baldme of plant consist ing of scrubber equipment for sulfur gases indl be in amothe yroup of $k$ id:

\subsubsection{TASK II. 6: SHAKEDOWN TESTING - 1. O-TPH BLACK LIQUOR RECOVERY UNITS}

Shakedown test ing of the gas if ier will be performed in order to establish mechanical integrity and operational reliability of the gasifier on start-ups and shutdowns.

\subsubsection{TASK II. 7: MANAGEMENT AND REPORTING}

This task is devoted to the proyram's lechical direction, in order to maintain the program hariware or cented, and to upport reporting functions required by the Dot Uniform Contract Report ming Syctem. Roports will include monthly, quarterly, and annua! reports as well as Management Plans and the annual update of such plans, including manower and other resource 
requirements. All projects in the program will be included in the reporting function in addition to the specific requirements of the DOE-sponsored projects.

\subsubsection{TASK II.8: MOVE AND INSTALL GASIEIER IN PULP MILL SITE}

The test unit will be transported to the host mill site and installed including interconnection of all required utility piping.

\subsubsection{TASK II.9: FIELD TESTS}

Gasification tests with black liquor will be performed in the 1.0.TPH unit. This effort includes the performance and documentation of all tests necessary to ensure that all components of the facility can and will be operated in a safe and responsible manner prior to achievement of full operational status. An operational test of 24 hours per day, 7 days a week for a mutually agreed upon term (not less than 1 week) will be required in this phase.

This effort includes a planned approach to fully assessing the performance capabilities of the system in accordance with the stated objectives, including (but not limited to) efficiency assessments, process chemistry anaiysis, system fuel handling, overall system operational flexibility, cost performance, system reliability, and all other information necessary to demonstrate the potential for commercial gasification of black liquor. The participants and DOt will negotiate a mutually agreeable operational schedule for this phase.

\subsubsection{TASK II.10: Remove Fielo TEST UNIT AND RESTORE HOST SITE}

At the successful conclusion of the field-test operation, the Participant shall remove the gasifier facility and restore the host site to as close to the original condition as possible to meet with the host mill manager's satisfaction. 


\section{SECTION 4.0 \\ ADDITIONAL BENCH-SCALE TESTS}

The design, development and recommissioning of the bench-scale integrated gasification unit along with the various tests conducted were reported in the previous annual report [1]. Additional characterization experiments were conducted with this unit in order to test some options such as freeboard black liquor drying and the partitioning of the gasifier bed. Eigure 4-1 shows the integrated bench-scale test unit.

\subsection{FREEBOARD DRYING TEST}

In the prior phase I gasification tests [1], it was realized that the raw product gas contained considerable amounts of sensible heat when exiting from the reactor at about $950^{\circ} \mathrm{F}$ (for a bed temperature of $1150^{\circ} \mathrm{F}$ ). This sensible heat could bo effectively utilized for drying and preheating the black liquor by freeboard spray injection (Figure 4-2).

A test was run on January 14, 1991, with a 'slack liquor injector installed at the lower part of the gasifier and another injector installed at the top of the gasifier. A total of 139 pounds of Kraft black 1 iquor from Longview was fed to the gasifier during the 6 hour duration of the test. The average feed rate was $22 \mathrm{lb} / \mathrm{hr}$ in which about $10 \mathrm{lb} / \mathrm{hr}$ was fed to the top injector and the balance of $12 \mathrm{lb} / \mathrm{hr}$ was fed to the injector normally used for all previous tests.

The average temperature of the gasifier bed and exit temperature are listed in Iable 4-1 together with the same temperatures recorded in a comparable test. It can be seen that the top feeding did increase the difference between the exit temperature and bed temperature but the increment was not significant. Table 4-1 also shows the product gas analysis. 


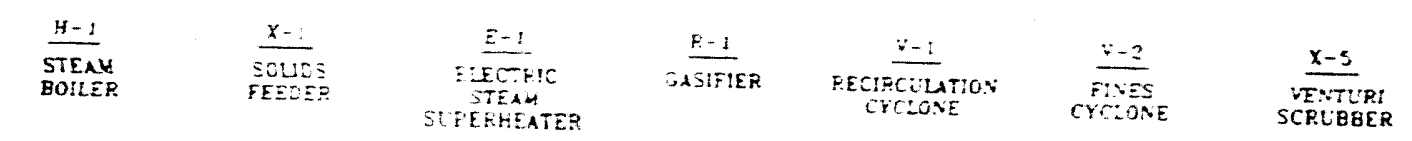

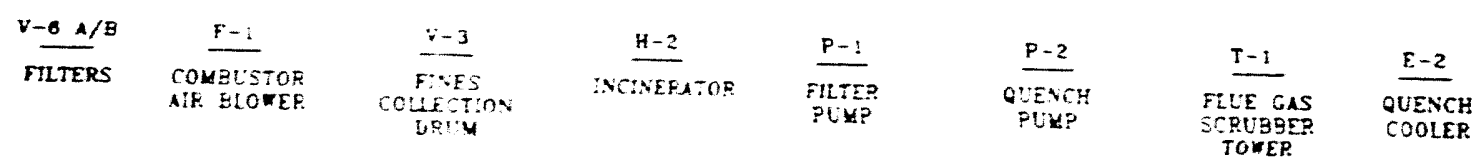

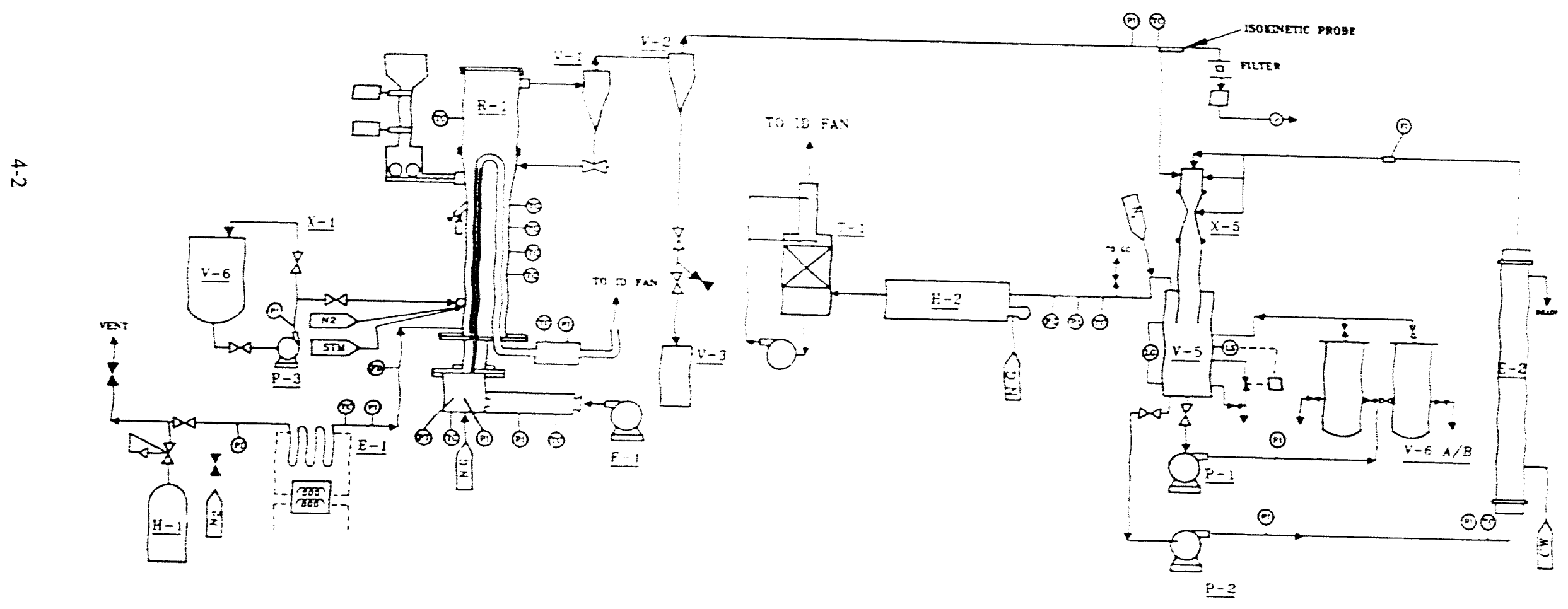

FIGURE 4-1: BENCH-SCALE TEST RIG 


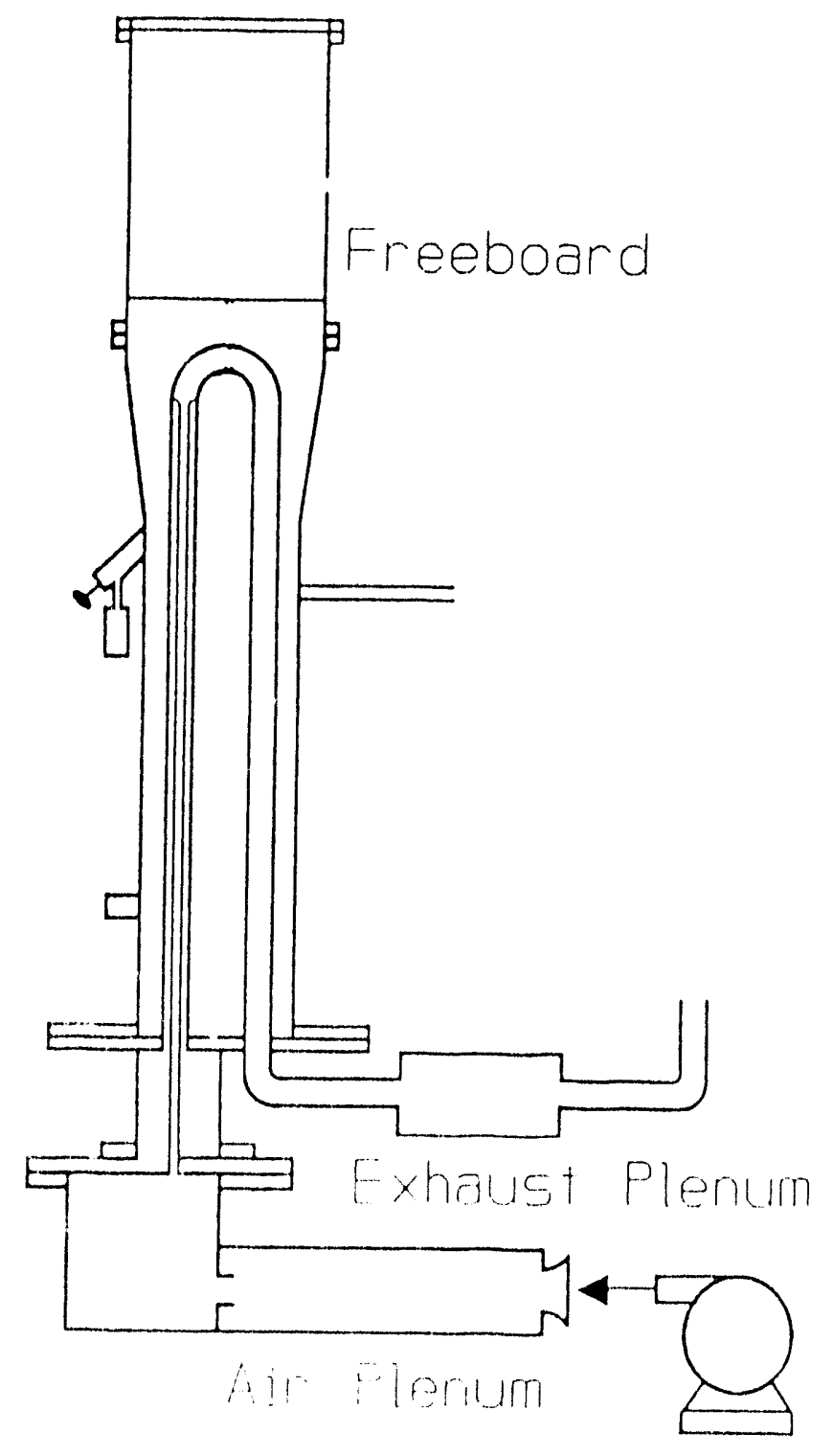

FIGURE 4-2: DRAWING OF THE GASIFIER REACTOR WITH BLACK LIOUOR INJECTION IN FREEBOARD 
TABLE 4-1:

COMPARISON OF GASIFIER TEMPERATURE AT

PARTIAL TOP FEEDING AND NORMAL FEEDING

\begin{tabular}{|c|c|c|}
\hline & $\begin{array}{l}\text { PARTIAL }(45 \%) \text { TOP } \\
\text { FEEDING }(1 / 14 / 91) \\
\end{array}$ & $\begin{array}{l}\text { NORMAL FEEDING } \\
(12 / 6,10) \\
\end{array}$ \\
\hline OPERATION DURATION (hours) & 7.5 & 5.5 \\
\hline AVERAGE BED TEMPERATURE $\left({ }^{\circ} \mathrm{F}\right)$ & 1147 & 1155 \\
\hline PRODUCT GAS TEMPERATURE $\left({ }^{\circ} \mathrm{F}\right)$ & 925 & 941 \\
\hline $\begin{array}{l}\text { DIFFERENCE BETWEEN BED TEMPERATURE } \\
\text { AND EXIT TEMPERATURE }\end{array}$ & 222 & 231 \\
\hline \multicolumn{3}{|l|}{ PRODUCT GAS ANALYSIS (Dry vol.\%) } \\
\hline $\mathrm{H}_{2}$ & 61.33 & 64.12 \\
\hline $\mathrm{CO}$ & 2.29 & 2.39 \\
\hline $\mathrm{CO}_{2}$ & 30.83 & 29.26 \\
\hline $\mathrm{CH}_{4}$ & 1.92 & 1.61 \\
\hline $\mathrm{C}_{2} \mathrm{H}_{4}$ & 0.14 & 0.13 \\
\hline $\mathrm{C}_{2} \mathrm{H}_{6}$ & 0.22 & 0.18 \\
\hline $\mathrm{C}_{3} \mathrm{H}_{6}$ & 0.10 & 0.07 \\
\hline $\mathrm{C}_{3} \mathrm{H}_{8}$ & 0.00 & 0.00 \\
\hline$c_{4}$ & 0.13 & 0.07 \\
\hline$C_{5}$ & 0.01 & 0.01 \\
\hline $\mathrm{H}_{2} \mathrm{~S}$ & 2.96 & 2.13 \\
\hline $\mathrm{CH}_{3} \mathrm{SH}$ & 0.07 & 0.03 \\
\hline TOTAL & 100.00 & 100.00 \\
\hline
\end{tabular}

\subsection{COMPARTMENTALIZED DRYING TEST}

As another alternative to making use of the sensible heat in the product gas was to dry the black 1 iquor feed, it was decided to test a compartmentalized or partitioned fluid-bed reactor. The two-tube reactor was divided into two chambers by vertically inserting a stainless steel plate (Figure 4-3) coated with a 1/8-inch ceramic fiber for insulation. The compartment on the hot side of the tube was used as high-temperature fluid bed for gasification 


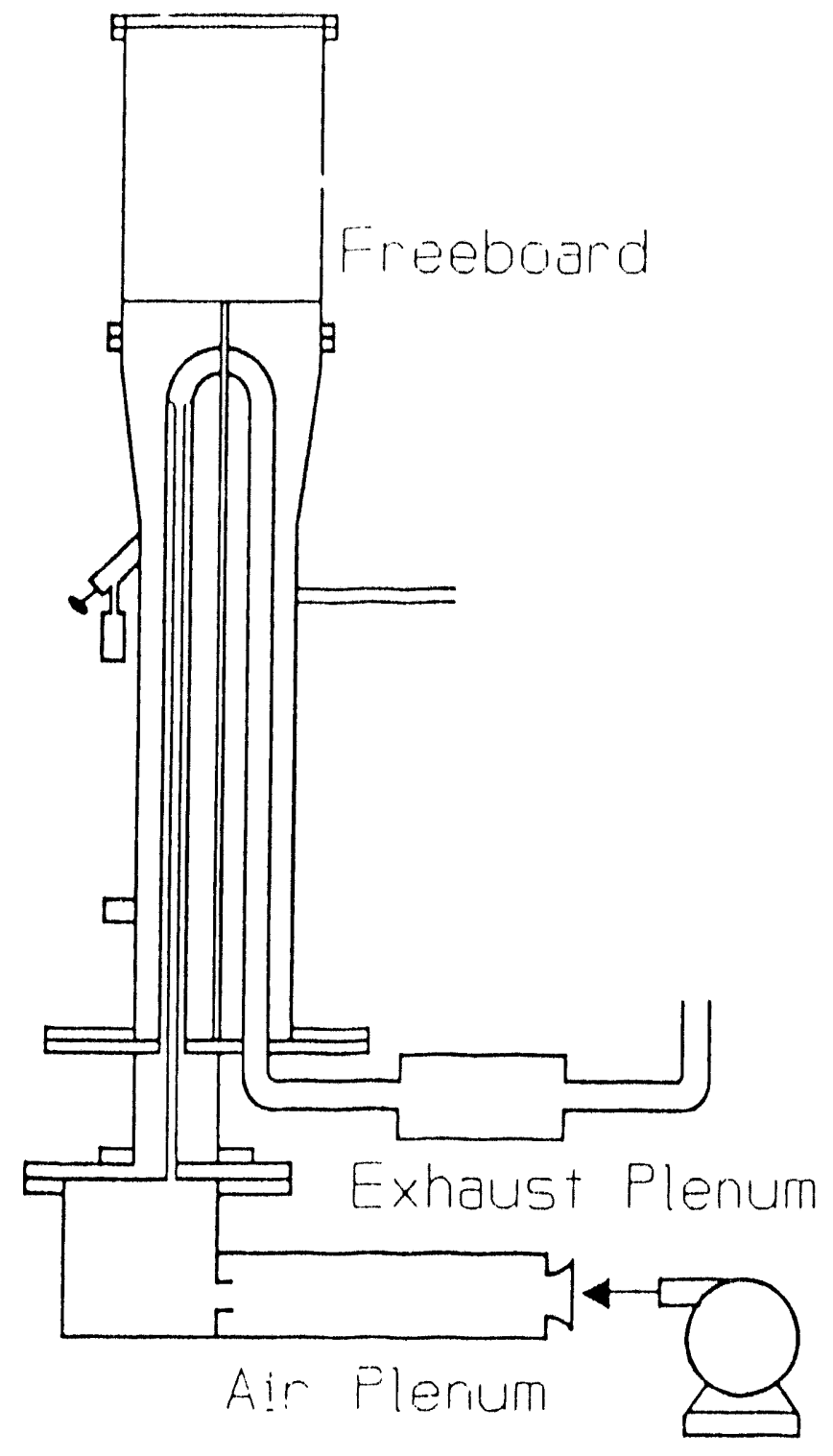

FIGURE 4-3: COMPARTMENTALIZED DRYING - REACTOR 
and the one on the return or cooler section of the U-tube was used as low temperature fluid bed used for drying the feed.

A test was run on March 22, 1991, to verify the operability of this modified gasifier. When the black liquor feed was started at a bed temperature of $950^{\circ} \mathrm{F}$, it was observed that while the cold side temperature remained at approximately $900-1000^{\circ} \mathrm{F}$, the hot side temperature kept rising. The feed rate was increased to maintain a hot side bed at approximately $1200^{\circ} \mathrm{F}$. The cold side bed temperature decreased to approximately $250^{\circ} \mathrm{F}$. The hot side temperature again began increasing. The feed rate was reduced in order to increase the cold side temperature but this further increased the hot side temperature. The test was terminated when the bed temperature rose to $1500^{\circ} \mathrm{F}$. The test history is shown in Figure 4-4.

After the reactor cooled down, an inspection of the bed revealed that most of the bed on both sides of the reactor had fused to form hard crusts on the surfaces and granular chunks inside. Even the insulating fiber seemed to have melted to form large chunks. The test clearly showed that the partitioned gasifier cannot be used for drying and gasifying, although it could be used for either one or the other of the above.

It was hypothesized that the partitioning with the heat insulated flate resulted in a large temperature differential between the two sides. Ihe cold side temperature was reduced significantly because of the evaporation of vater in the black liquor feed, whereas the hot sido bed did not have sifficient material to be gasified resulting in an increase in hot site lempe ature. Figure 4-5 shows the temperature profile at 12:00 befor: the conbustor was turned off. At that time, the fluidization was yood and no agulomeration seemed to be occurring from the gradually disiributed temperature. However, the bed sample taken at this time did have several larger pieces showing that the bed grains started sticking together due to the slow drying process.

The added metal plate also reduced the space betweon the heater thes Some narrow spots between the heater tubes and the metal plate became : ites for agglomeration. Once agglomeration started, the fluidization could not be 

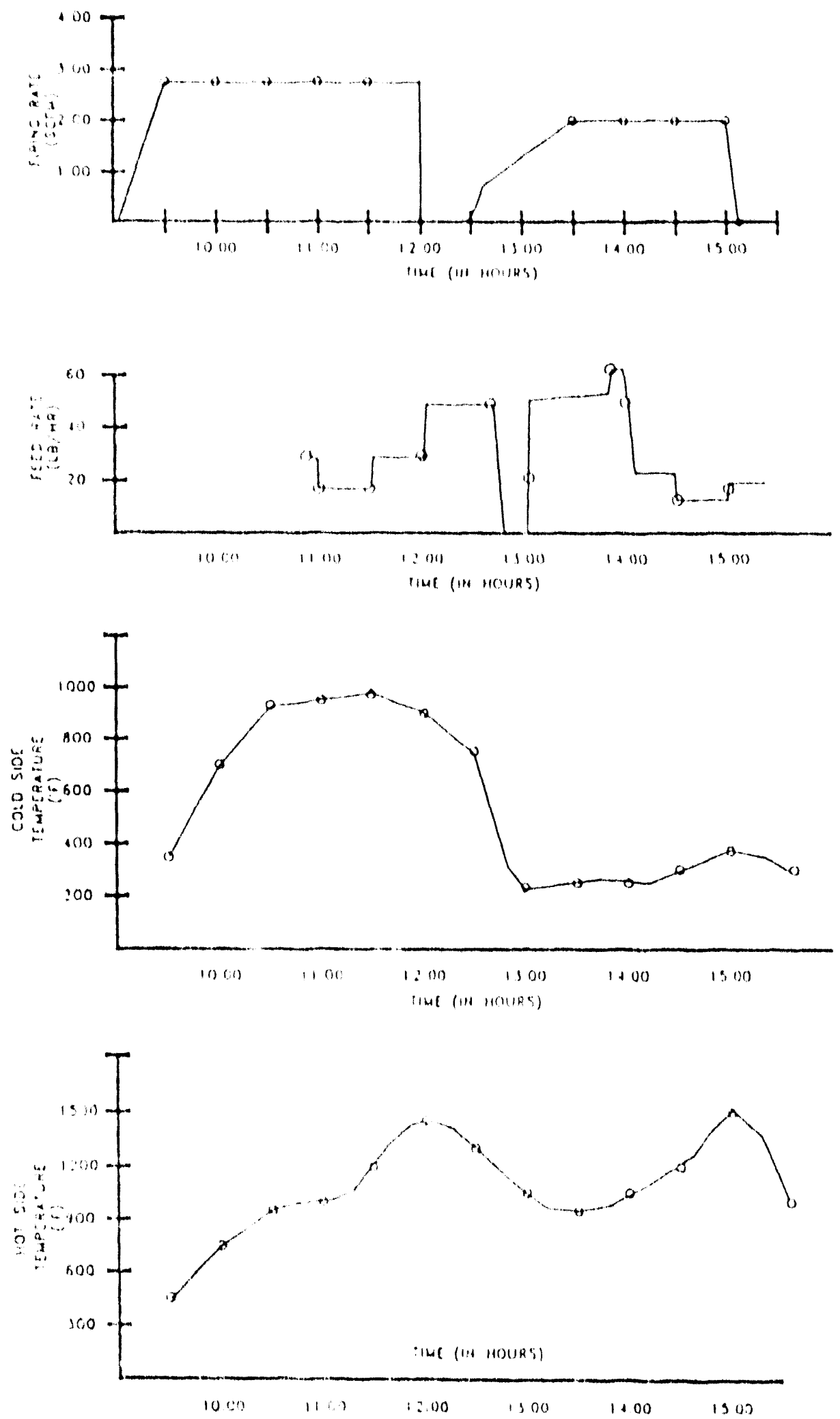

FIGURE 4-4: COMPARTMENTALIZED REACTOR GASIFICATION TEST HISTORY 
8-6

$00: 2[1 \forall$ 3าI J0yd $\exists y n \perp \forall y \exists d W \exists \perp$

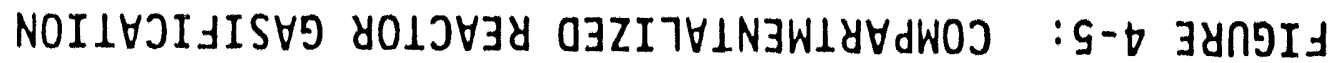

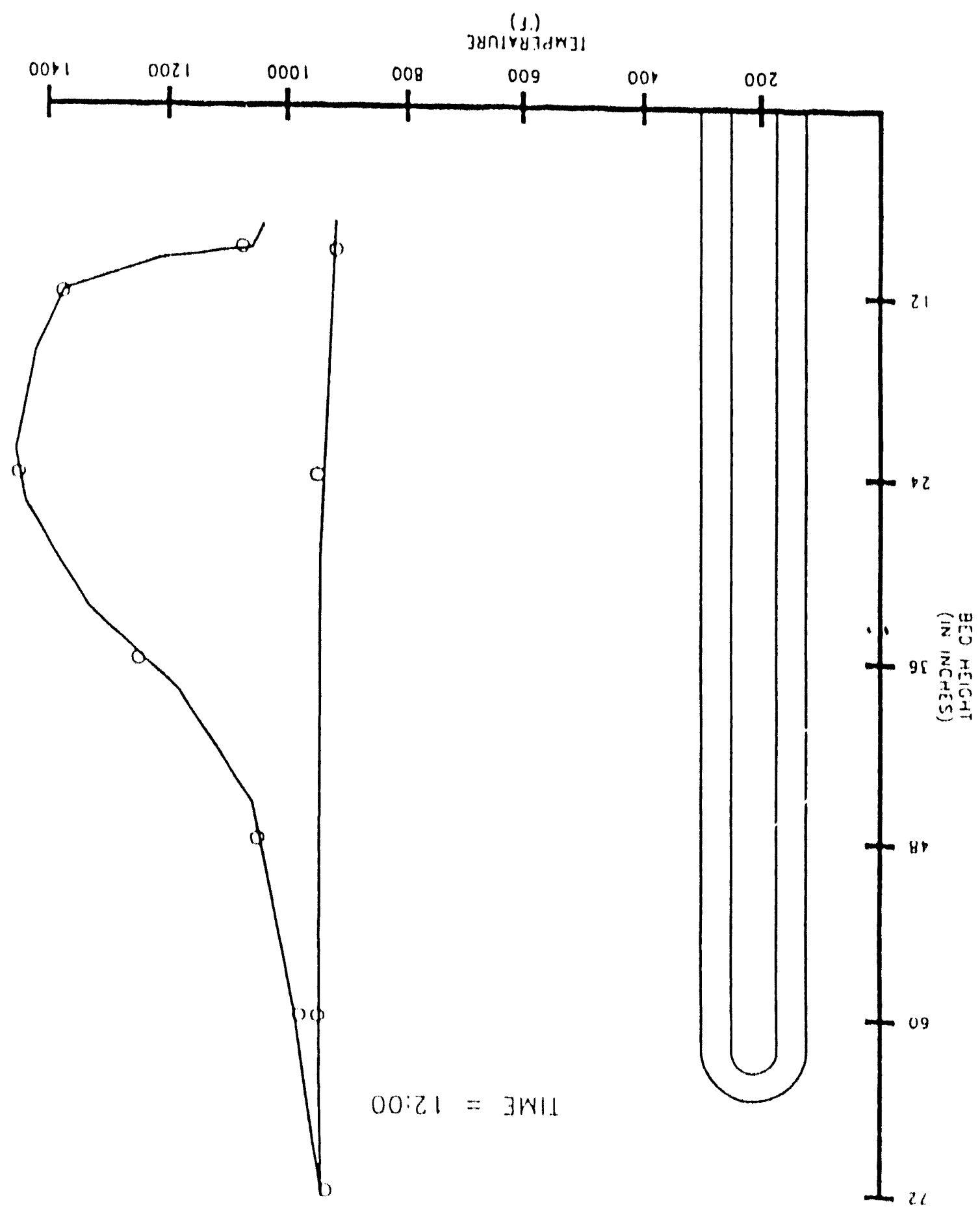


maintained properly and the temperature divergence grew 1arger. Figure 4-6 shows the temperature profile at 15:00 when operation of the reactor became very difficult to handle and led to the termination of the test.

The reduced reactor cross-section in the cold compartment reduced its ability to dry black liquor. It can be seen from figure 4-4 at 12:00 that the feed rate was increased which resulted in a decrease of the bed temperature. Further increase in the feed rate caused even faster decline of the bed temperature. When the temperature was too low for rapidly drying the black liquor on the surface of the bed, the bed started to aggregate at the upper part where the temperature was high enough to dry the wet surface so that the bed particles began to agglomerate.

In general, the structure of the partitioned two-tube gasifier presented a dilemma: With a small feed rate, the cold side was able to dry the liquor and form a well-coated bed grain but was not able to supply sufficient bed carbon for gasification in the hot side. On the other hand, a higher feed rate might be able to transport enough carbon to the hot side but not be able to dry the liquor properly. To solve this problem, a two-stage gasifier was suggested and is illustrated in Eigure 4.7. This structure may be operated properly but with increased complexity of solid lift mechanics. 


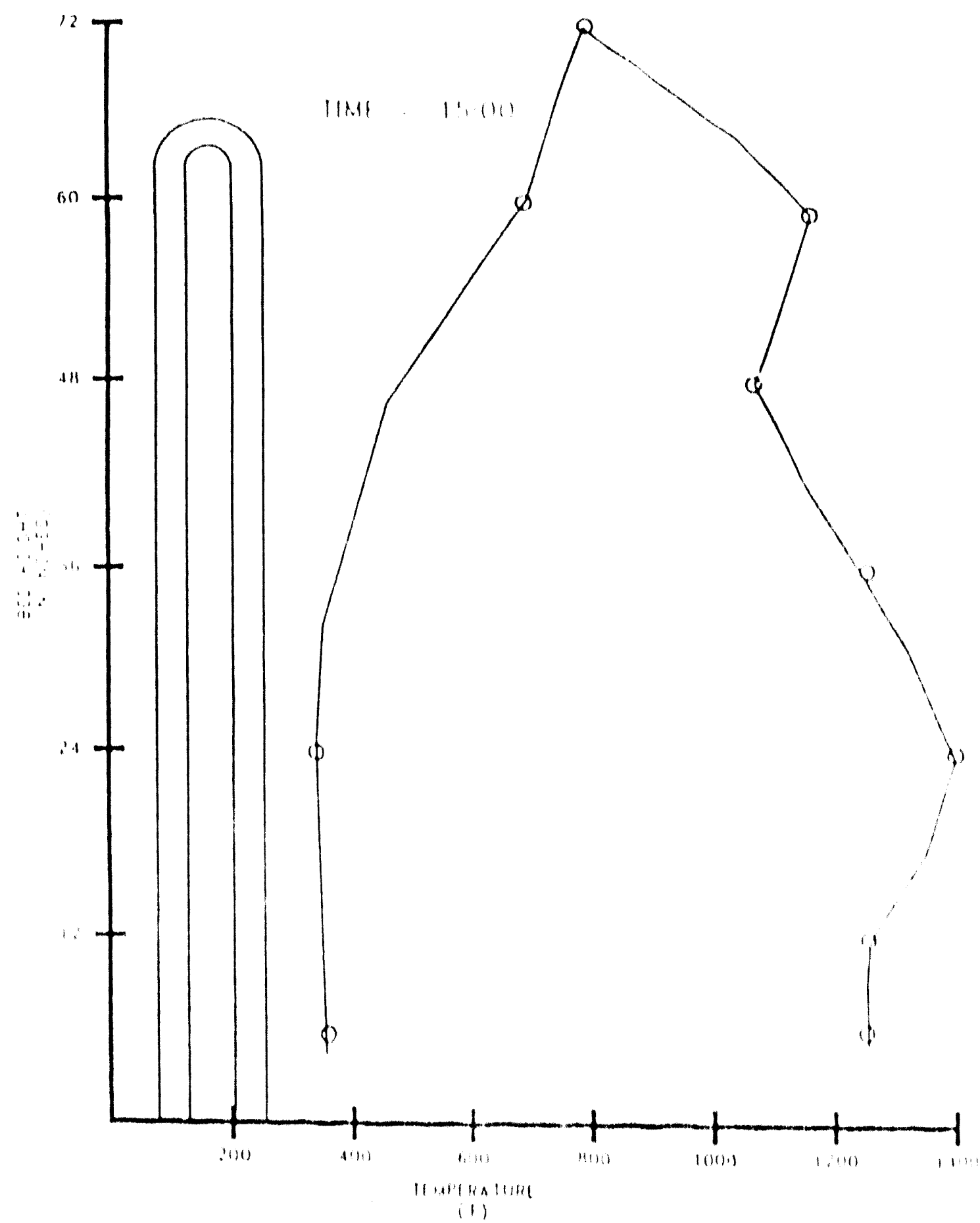

FIGURF 4-6: COMPARTMENTALIZED REACTOR GASIFICATION TEMPERATURE: PROFILE AT $3: 00$ 


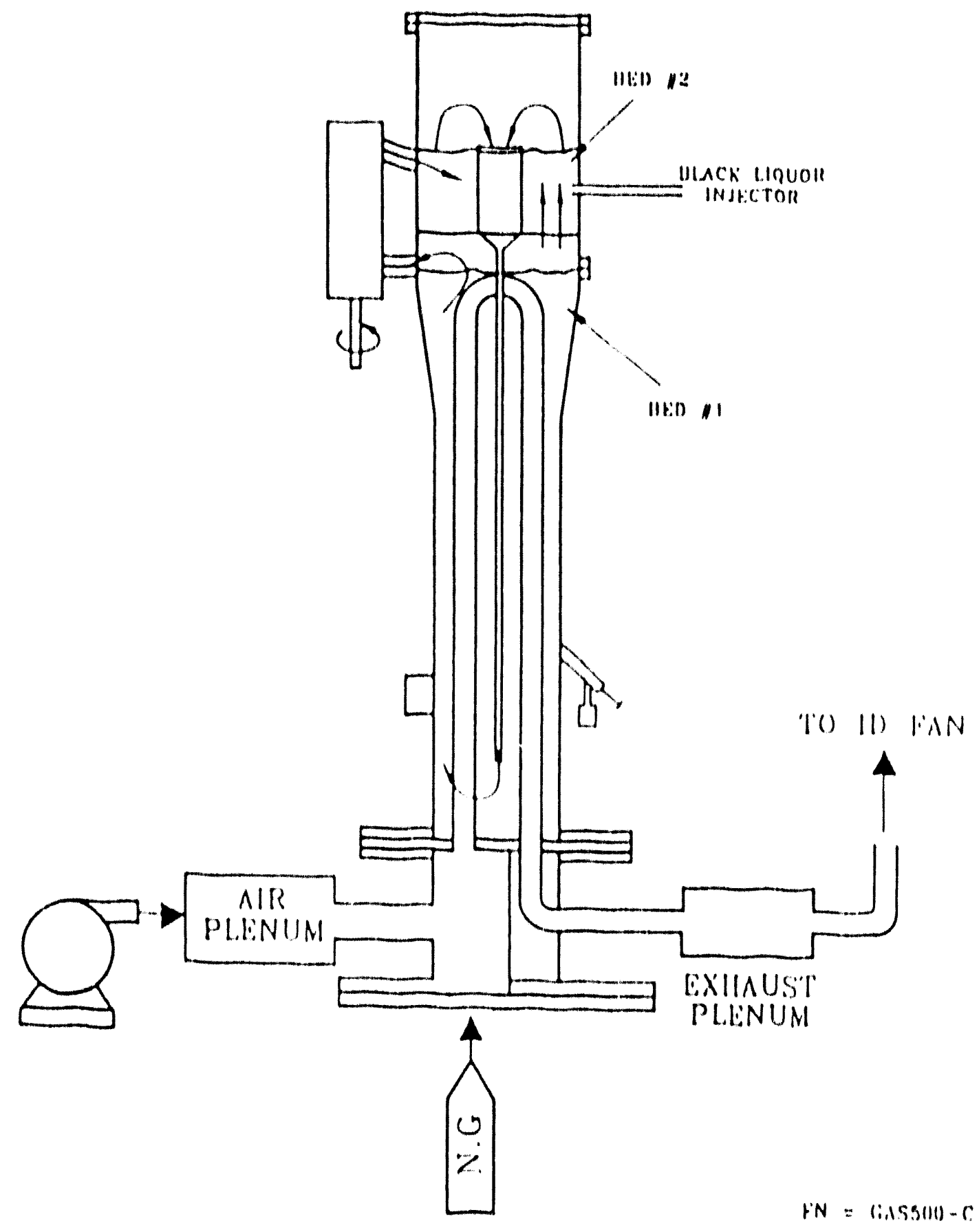

FIGURE 4-7: COMPARTMENTALIZED REACTOR SUGGESTED CONFIGURATION 
SECTION 5.0

\section{DEVELOPMENT AND TESTING OF A PROTOTYPE 61-TUBE CUMBUSTOR HEATER MODULE}

\subsection{DESIGN AND DEVELOPMENT}

The data base gathered during the extensive bench-scale testing provided a significant amount of information for the design and development of the scaled-up field test unit. However, it was realized that a 1/2-5cale prototype model of the pulse tube heater should be designed and tested in order to ensure that the key hardware component would perform rellably in service. A program was initiated to design, fabricate and test a heater module with a nominal firing rate of $5 \times 10^{6} \mathrm{Btu} / \mathrm{hr}$ and capable of processing 1/2 TPH of black liquor solids, which is half the capacity of the proposed field test unit. The prevlous annual report [1] described most of the developmental design and fabrication activities for this unit but will be briefly summarized here for continulty.

The prototype $5 \mathrm{MMBt} / \mathrm{hr}$ pulsating tube heater module consisted of 61 , 15 inch diameter, partially shielded tubes arranged in a hexagonal staggered array and spaced on 3 -inch centers. The tubes were supported on several vertical baffles and longitudinal tie rods. The tube bundle was fabricated by REPCO Engineering and is shown in Eigure 5-1. The tube bundle forms the resonating member of the pulsating heater module, and is fully immersed in the fluid bed under operating conditions.

An exploded view of the pulse heder module is shown in Elgure 5-2. The pulse heater module comprises four main elenents: an air inlet plenum, pulse combustor, tube bundle, and flue gas exit plenum. Air is supplied to the air inlet plenum from a forced draft fan. The air is then aspirated into the pulse combustor through four separate aerovalves. Fuel is injected into the pulse combustor through a series of distributed nozzies surrounding the aerovalve. The combustion products then enter the tube bundle where the heat is transferred to the fluid bed. The cooled combustion gases are collected in a flue gas plenum and vented through a muffler to the stack. 


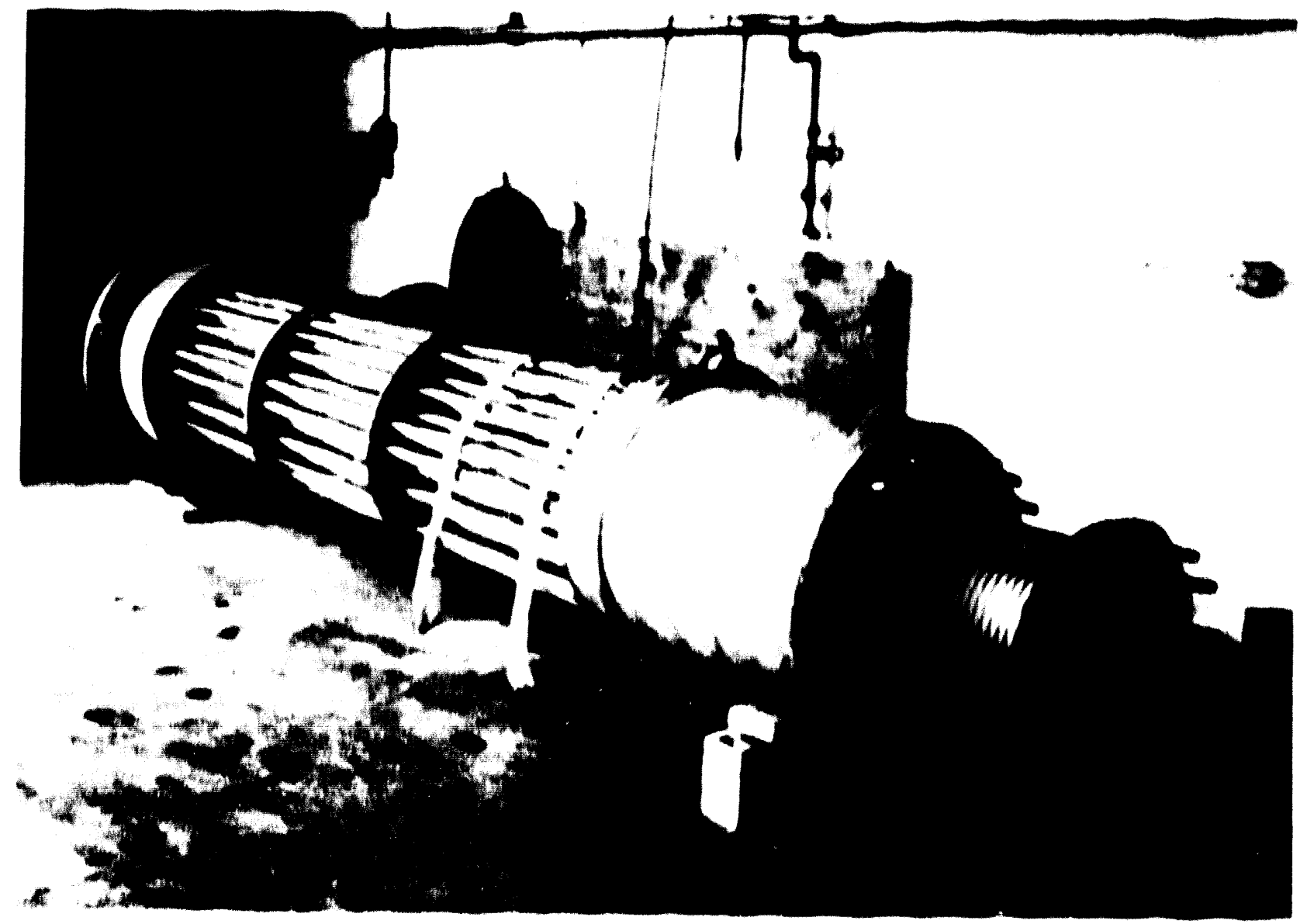

FIGURE 5-1: FULL-SCALE PULSE HEATER MODULE 


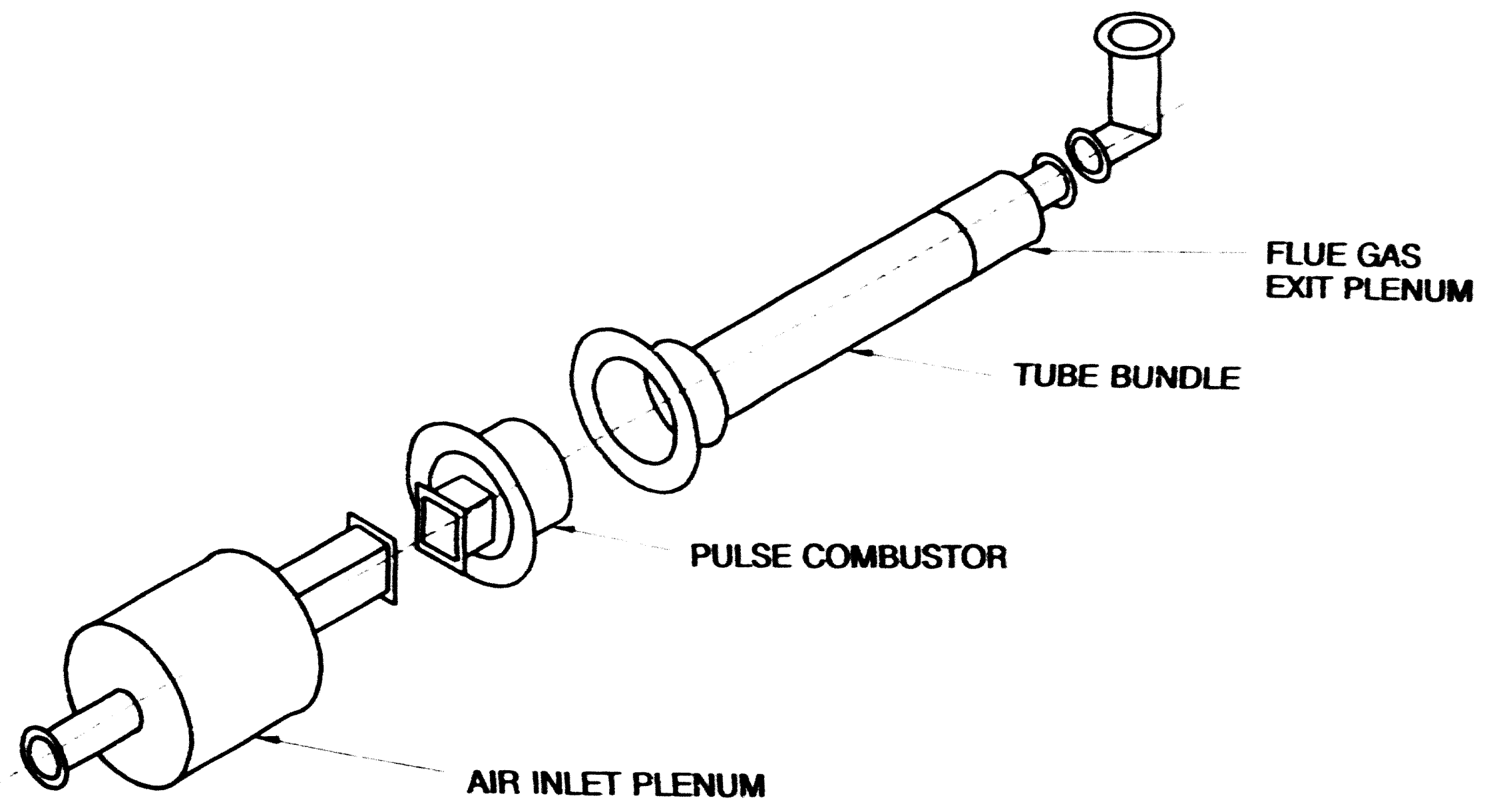

FIGURE 5-2: EXPLODED VIEW OF PULSE HEATER MODULE 
A schematic of the interface between the pulse combustor and the tube sheet with the tube bundle is shown in Eigure 5-3.

\subsection{TESTING}

A series of tests were cunducted with the 61 -tube prototype heater bundle. The experimental set-up is shown in ligures 5-4 and 5-5. The previous annual report [1] contained the results of a few preliminary tests conducted with this 61-tube set-up. This report discusses the follow-up tests with a different gas injector and other design improvements incorporated thereafter. A continuation of the developmental tests to collect data on the 61-tube heater bundle were conducted with the module operating over a range of firing conditions. A test summary is presented in lable 5-1.

As evident from lable 5.1 , the nominal firing rate range $(4.65-5.73$ MMBtu/hr) about the rated $5 \mathrm{MMBtu} / \mathrm{hr}$ capacity of the heater was used to test the performance at the design capacity for relatively long test times. Each of the two tests were run for about 3 to 4 hours at the indicated firing rates. The air flow (excess air) was varied by adjusting a fan damper. The back pressure was created by an orifice plate placed in the flue stack to simulate the conditions under actual operation with a waste heat boiler and muffler following the flue gas exhaust from the tube bundle. As seen in Iable 5.1, the back pressure varied between 7 and 8 inches of water column.

Although the actual design operating temperature of the gasifier for the field test will be approximalely $1100^{\circ} \mathrm{F}$, a maximum average bed temperature of approximately 850 to $900^{\circ} \mathrm{F}$ could be achieved in this prototype test unit over the duration of the operation. However, this temperature was sufficiently close to the actual operating temperature to provide combustion and heat transfer data that could be projected accurately to the design values.

The tube surface temperatures labeled 1 to 0 are at the locations shown in Eigure 5.6. The results of the tests show a temperature difference of less than $250^{\circ} \mathrm{F}$ between the bed and the tubes. That was close to the values predicted by MICl's simulation models. This temperature difference must be small enough to avoid any hot spots and subsequent bed agglomeration. 


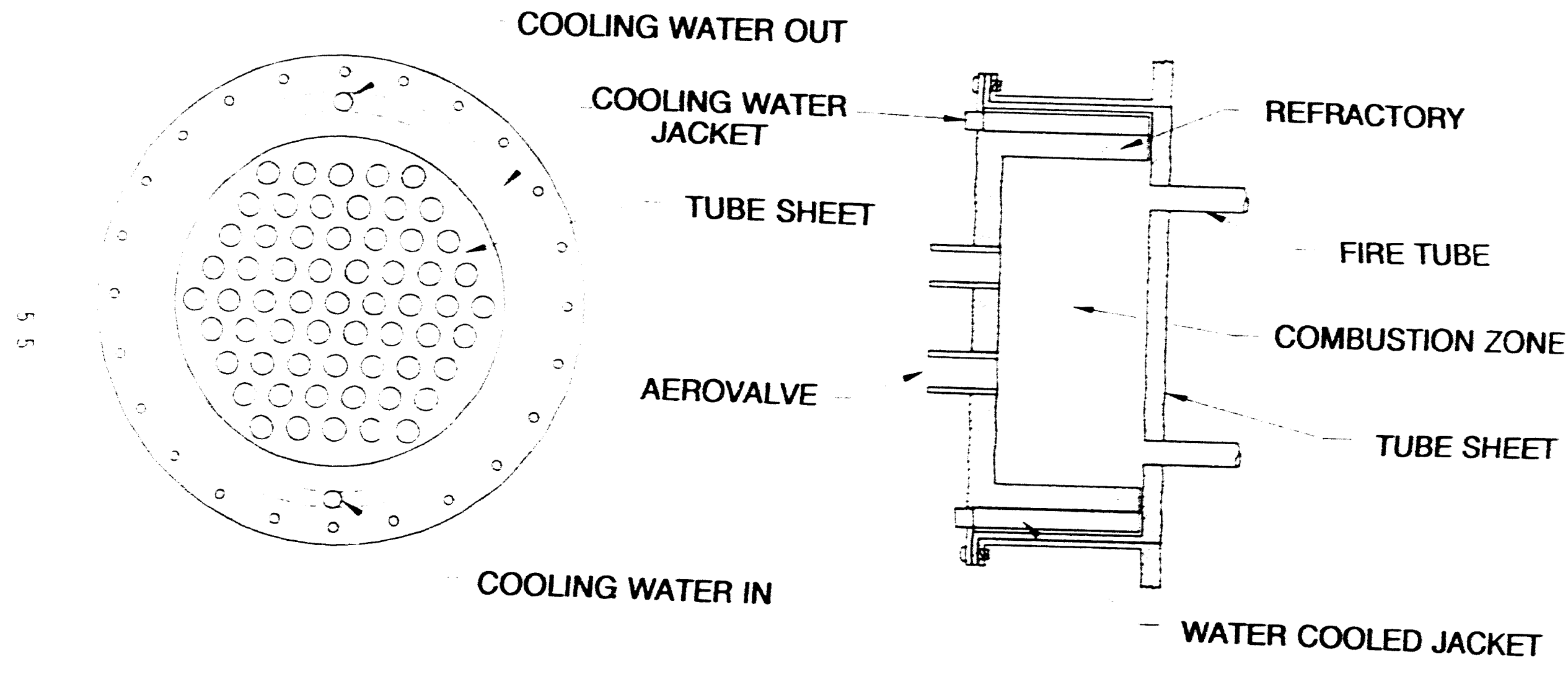

FIGURE 5-3: COMBUSTOR TUBE BUNDLE. INTERFACE 


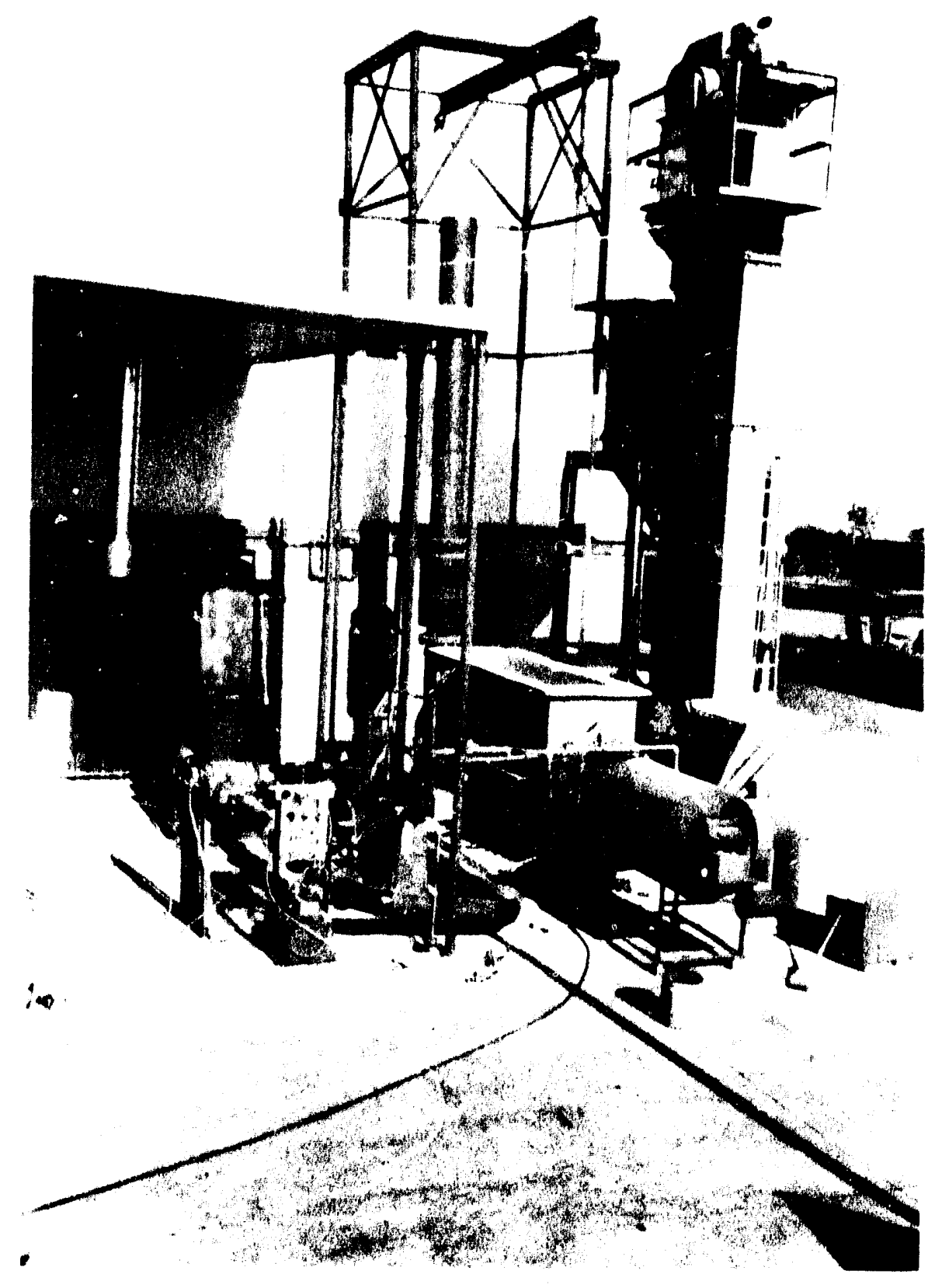

FIGURE 5-4: EXPERIMENTAL SETUP 

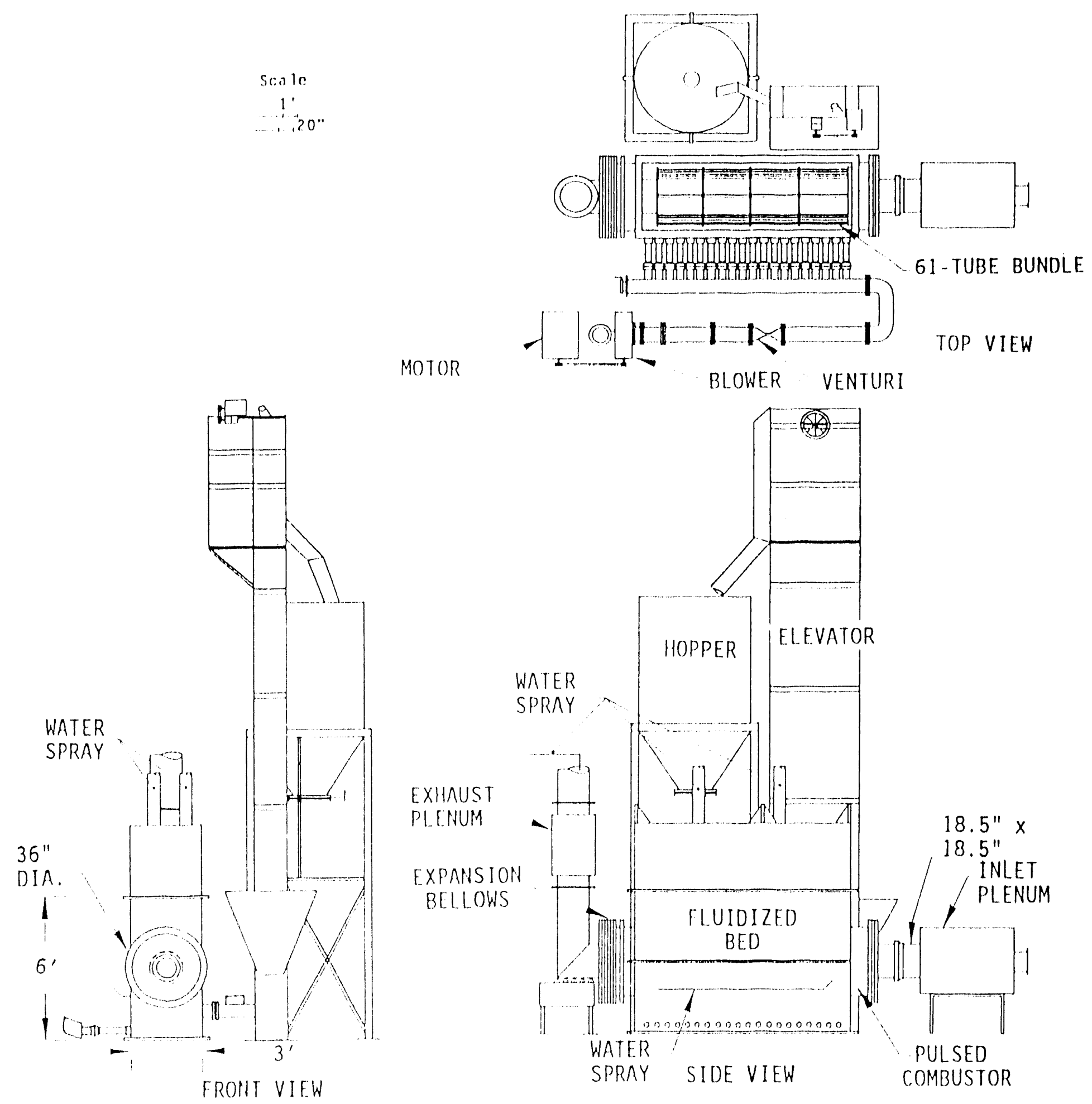

FIGURE 5-5: SCHEMATIC OF THE TEST SETUP 
TABLE 5-1:

\section{COMBUSTION PERFDRMANCE OF THE 61-TUBE PULSE HEATER}

\begin{tabular}{|c|c|c|c|c|c|c|c|c|c|c|c|c|c|c|c|c|c|}
\hline \multirow{2}{*}{$\begin{array}{c}\text { TOTAL } \\
\text { FR } \\
\text { METU }\end{array}$} & \multirow{2}{*}{$\begin{array}{c}\text { EXCESS } \\
\text { AIR } \\
\vdots\end{array}$} & \multirow{2}{*}{$\begin{array}{c}\text { AIR } \\
\text { PLENUM } \\
\text { PRESSURE } \\
\text { (" A : }\end{array}$} & \multirow{2}{*}{$\begin{array}{l}\text { STAC } \\
\text { 3ACk } \\
\text { PQESSURE } \\
\text { - }\end{array}$} & \multirow{2}{*}{$\begin{array}{c}\text { DEFAGE } \\
\text { SED } \\
\text { EMO } \\
Y\end{array}$} & \multirow{2}{*}{ 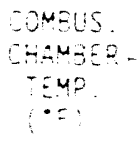 } & \multicolumn{6}{|c|}{ TUBE SKIN TEMPERATURE ( } & \multirow{2}{*}{$\begin{array}{l}\text { TUBE } \\
\text { SHEET } \\
\text { EHP: } \\
\text { TC=7 }\end{array}$} & \multirow{2}{*}{$\begin{array}{l}\text { STACK } \\
\text { TEMP } \\
\text { OF } \\
\text { TC=: }\end{array}$} & \multicolumn{4}{|c|}{ FLUE GAS ANALISIS } \\
\hline & & & & & & $\because=1$ & $r=2$ & $t \div 3$ & $T C=1$ & $i s=z$ & $r=5$ & & & 02 & $\underset{(\boldsymbol{*})}{\text { COMB. }}$ & $\begin{array}{l}c 0 \\
(p o m)\end{array}$ & $\begin{array}{l}\text { NOx } 3 \quad 3 \% \\
02(00 m)\end{array}$ \\
\hline \multicolumn{18}{|c|}{ TEST $\$ 120790$} \\
\hline$\therefore=$ & $: 0 \vdots \vdots$ & $: 3.3$ & $\equiv 3$ & $\xi:$ & 2392 & $: 20$ & $: 000$ & 385 & $35 i$ & $9 \div 0$ & 943 & 1150 & $: \div 95$ & 2.3 & 0.2 & $\vdots \Xi$ & 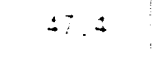 \\
\hline$\therefore \Xi$ & 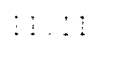 & $:: .0$ & $\equiv 2$ & $\Xi E \equiv$ & 2230 & $.02^{-}$ & $59 i$ & $: 011$ & 956 & $9: 5$ & 970 & 1180 & $: 498$ & $2 .:$ & 0.2 & $\therefore \div$ & $\therefore \%$ \\
\hline$\therefore 9$ & $\therefore: 70$ & $\therefore 2$ & -5 & $38:$ & $: 3: 5$ & $\therefore 28$ & $\Xi \Xi \Xi$ & 377 & 960 & 930 & $\Xi \vdots \vdots$ & $\therefore: \Xi$ & $\therefore: 95$ & 2.2 & 3.2 & 22 & $\because \vdots:$ \\
\hline \multicolumn{18}{|c|}{ TEST $\$ 121290$} \\
\hline$\therefore 55$ & 11.70 & $: 3.0$ & 23 & $3: 0$ & 2380 & .055 & 980 & $1: 47$ & $: 017$ & 285 & 1050 & $: 282$ & $: 470$ & 2.2 & 0.1 & $\$ 3$ & $\vdots 3.3$ \\
\hline 4.85 & 12.30 & 13.0 & $\therefore$ & 855 & 2382 & 1250 & 950 & 1150 & 1093 & 985 & 1067 & $: 297$ & 1475 & 2.4 & 0.1 & 44 & $33 .:$ \\
\hline$\therefore .35$ & 15.28 & $: 3.0$ & $\therefore .0$ & $36:$ & Z:Q: & .050 & 375 & $: 235$ & 1062 & 383 & $: 053$ & $: 292$ & $: \div 65$ & 2.2 & 0 & $\therefore 5$ & 39.5 \\
\hline 5.26 & 3.25 & : ¿. & 7.5 & $39 ?$ & $24: 5$ & 1285 & 393 & $1: 380$ & 1245 & 1019 & 1067 & $: 327$ & 1535 & 1.5 & 0.1 & - & 45.4 \\
\hline$\Xi .25$ & 9.31 & .3 .0 & $7 . \equiv$ & 370 & 2405 & 1065 & 970 & 1195 & 1128 & 1000 & 1058 & $! 321$ & 1519 & 1.7 & 0.1 & 22 & 45.5 \\
\hline
\end{tabular}


6. 9

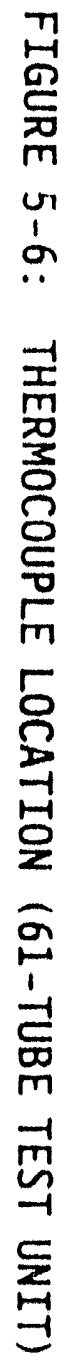

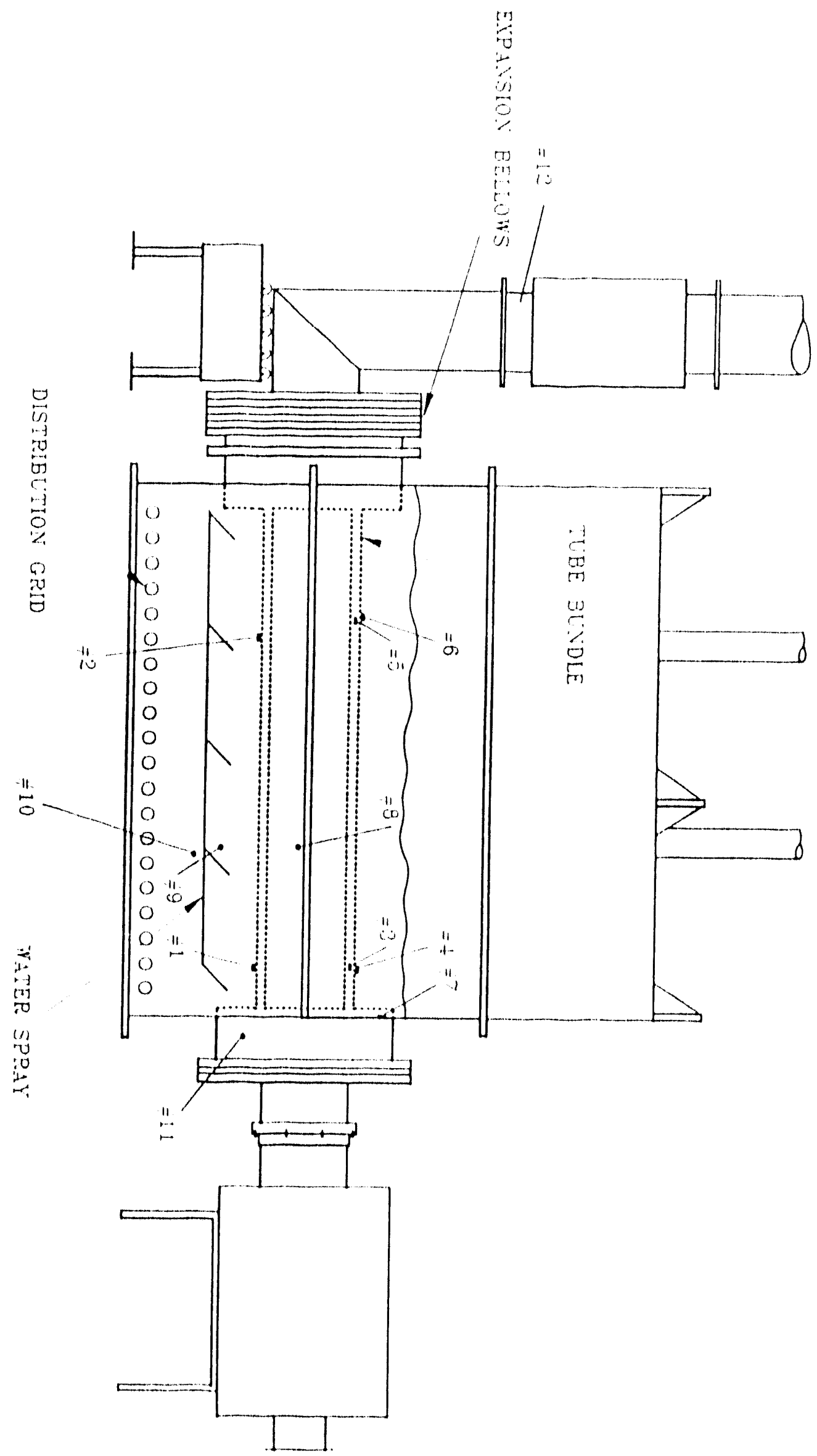


Eiqure 5-7 shows the combustion performance of the heater module with respect to $\mathrm{NO}_{\mathbf{x}}$ emissions (see also Table $5-1$ ). The general trend of the $\mathrm{NO}_{\mathbf{x}}$ emission data shows an increasing $\mathrm{NO}_{\mathrm{x}}$ value with decreasing excess air. This is to be expected as the $\mathrm{NO}_{x}$ emissions reach a maximum at zero excess air because low excess air results in higher combustion temperature and hence higher thermal $\mathrm{NO}_{x}$ formation. The $\mathrm{NO}_{x}$ values obtained for this heater bundle are considerably lower than existing equivalent capacity combustion systems. The values are expected to be significantly lower when the combustor is fired with the hydrogen-rich product gas instead of the natural gas used for the tests. The values of the combustibles were observed to be significantly low (Table 5-1) at all firing rates and for the entire range of excess air. co emissions were also observed to be quite low. This is a significant factor for the future sales of the equipment because of the motivation for most paper mills to reduce emissions from their process without expensive posttreatment.

\subsection{SOME MAJOR DESIGN PARAMETERS/CHANGES OBTAINED OR INCORPORATED DURING THE PROTOTYPE TESTING}

1. The modified gas injector (Figure 5-8) improved the firing rate range to $2.7-6.6 \times 10^{6} \mathrm{Btu} / \mathrm{hr}$. This improved design would be incorporated into the field test combustor unit.

2. The combustion chamber and the tube sheet will be water jacketed since the prototype module tests resulted in the center of the heater getting hotter than the periphery of the module, causing the tabes in the center to elongate up to $气 "$ more than the outer tubes. This deformed the tube sheet somewhat and caused some weld failure. The water-jacketed tube sheet will eliminate this problem.

3. In order to obtain a more uniform radial temperature distribution across the tube sheet and tube bundle as an alternative to watercooled tube sheet a fifth aerovalve without an injector was installed at the center of the combustor flange. Two tests were run under similar conditions in order to determine the effect of this fifth 


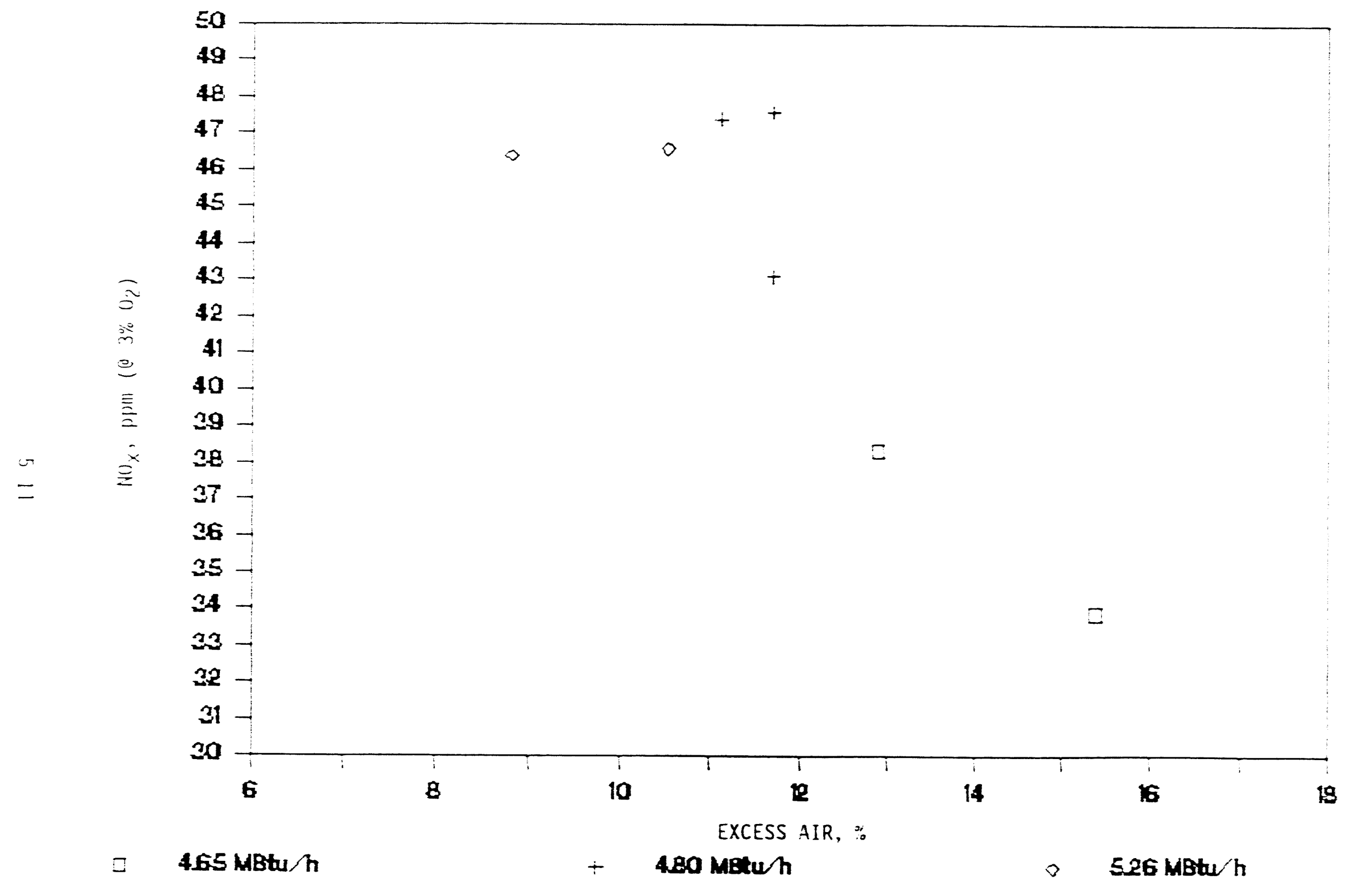

FIGURE 5-7: $\mathrm{NO}_{\mathrm{X}}\left(\mathrm{e}_{3} \frac{\mathrm{O}}{6} \mathrm{O}_{2}\right)$ vS. EXCESS AIR 


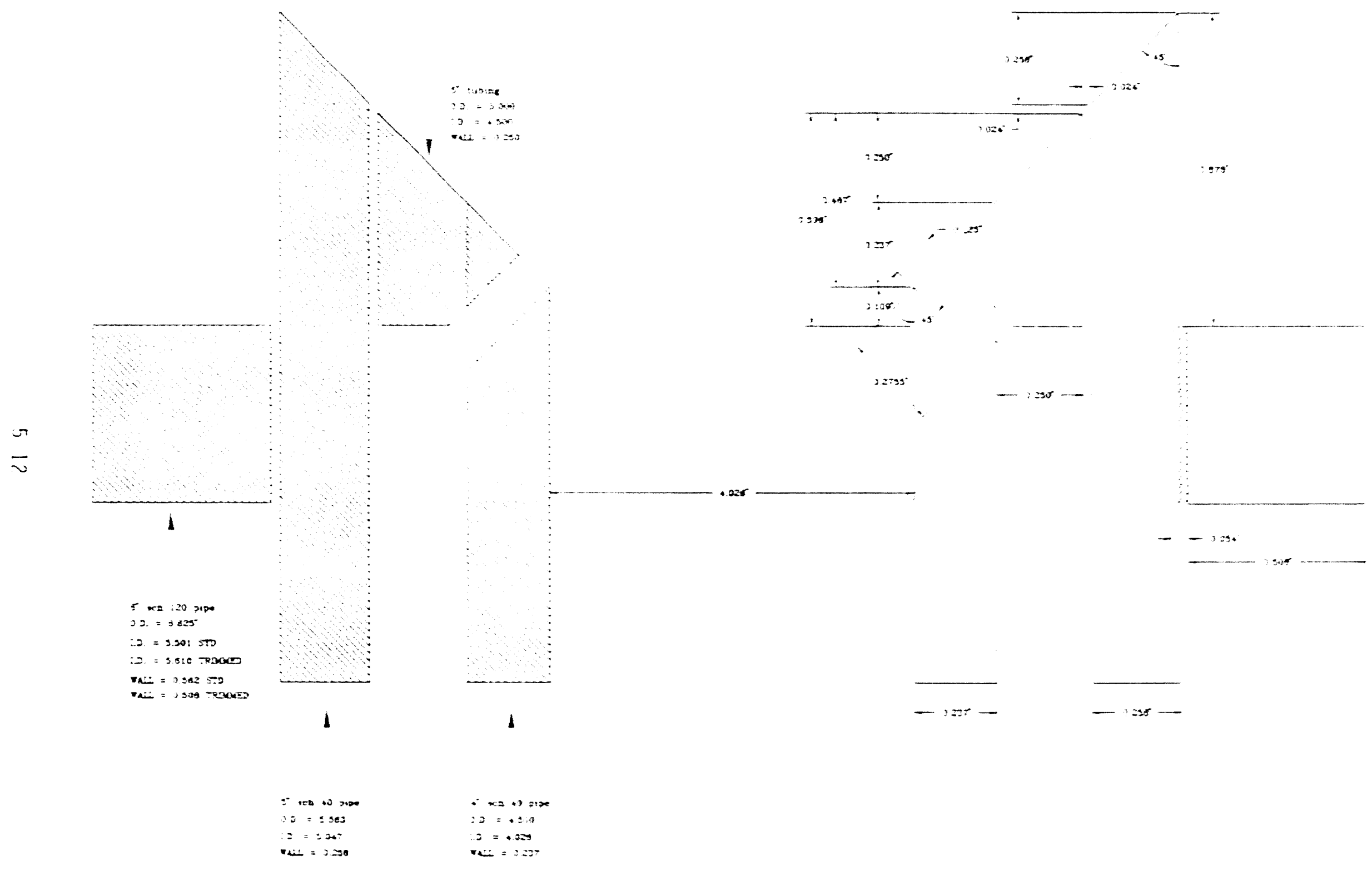

FIGURE 5-8: SCHEMATIC OF NEW GAS INJECTOR TIP DESIGN 
aerovalve - one without the valve, another with the valve. The results are shown in lable 52. As can be seen from the table, the temperature difference between the center and periphery of the tube decreased from approximately $500^{\circ} \mathrm{F} 10100^{\circ} \mathrm{F}$. The five-aerovalve con. figuration also resulted in reduced average tube wall temperatures. The five aerovalve configuration was used for the pilot-scale test combustor unit.

4. The computer simulation for energy and mass balance for the New Bern field test unit indicated the need for about 230 pulse tubes, each with a firing rate of $80 \mathrm{KBtu} / \mathrm{hr}$. The 61 -tube prototype had provided valuable information on the design and fabrication of the heater bundles. Based on these activities, it was decided to use three heater bundles, each with 72 tubes, instead of four 61 tube bundles, or one 221-tube bundle. For the given overall diameter, the hexa. gonal arrangement of pulse tubes within this diameter allowed for 61, 72, and 84 tube units. A 72 -tube unit was preferred as it provided sufficient space for refractory and a cooling water jacket around the combustion chamber.

\subsection{COMPARTMENTALIZED GASIFIER TESTING}

In order to further investigate techniques for maximum utilization of the product gas sensible heat, a compartmentalized reactor configuration was investigated with the prototype 61 - lube heat module as an extension of the earlier tests on the bench-scale unit. Theoretical analys is and computer simulations indicated that a considerable reduction in capital cost could be realized with the compartmentalized configuration. Modifications were made to the gasifier vessel, cyclones, combustion plenum, and the stack to experimentally verify the findings. Two different configurations were investigated. 


\section{TABLE 5-2:}

\section{COMPARISON OF \& AND 5 AEROVALVE CASES}

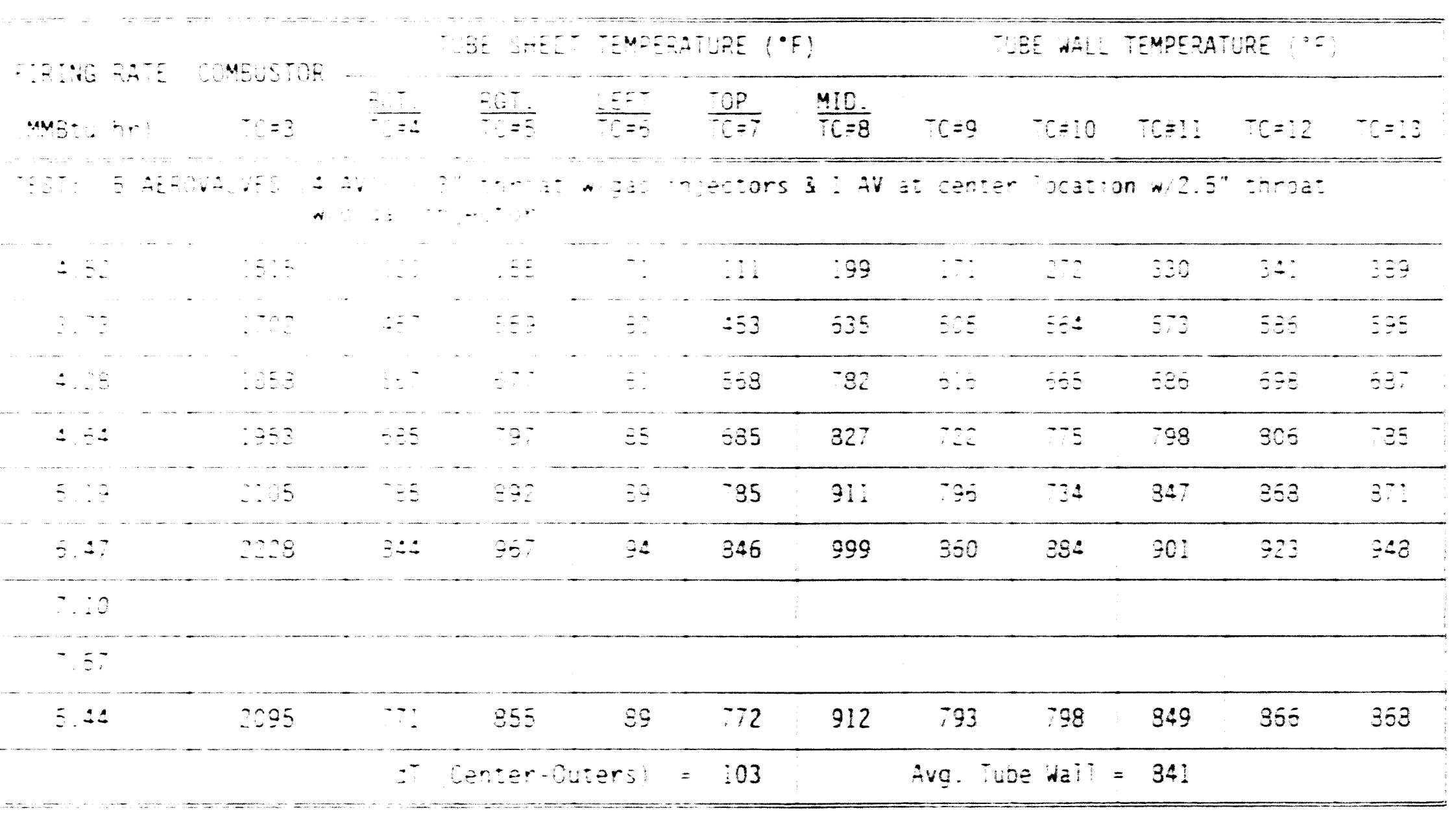


TABLE 5-2:

\section{COMPARISON OF 4 AND 5 AEROVALVE CASES (CONT'D)}

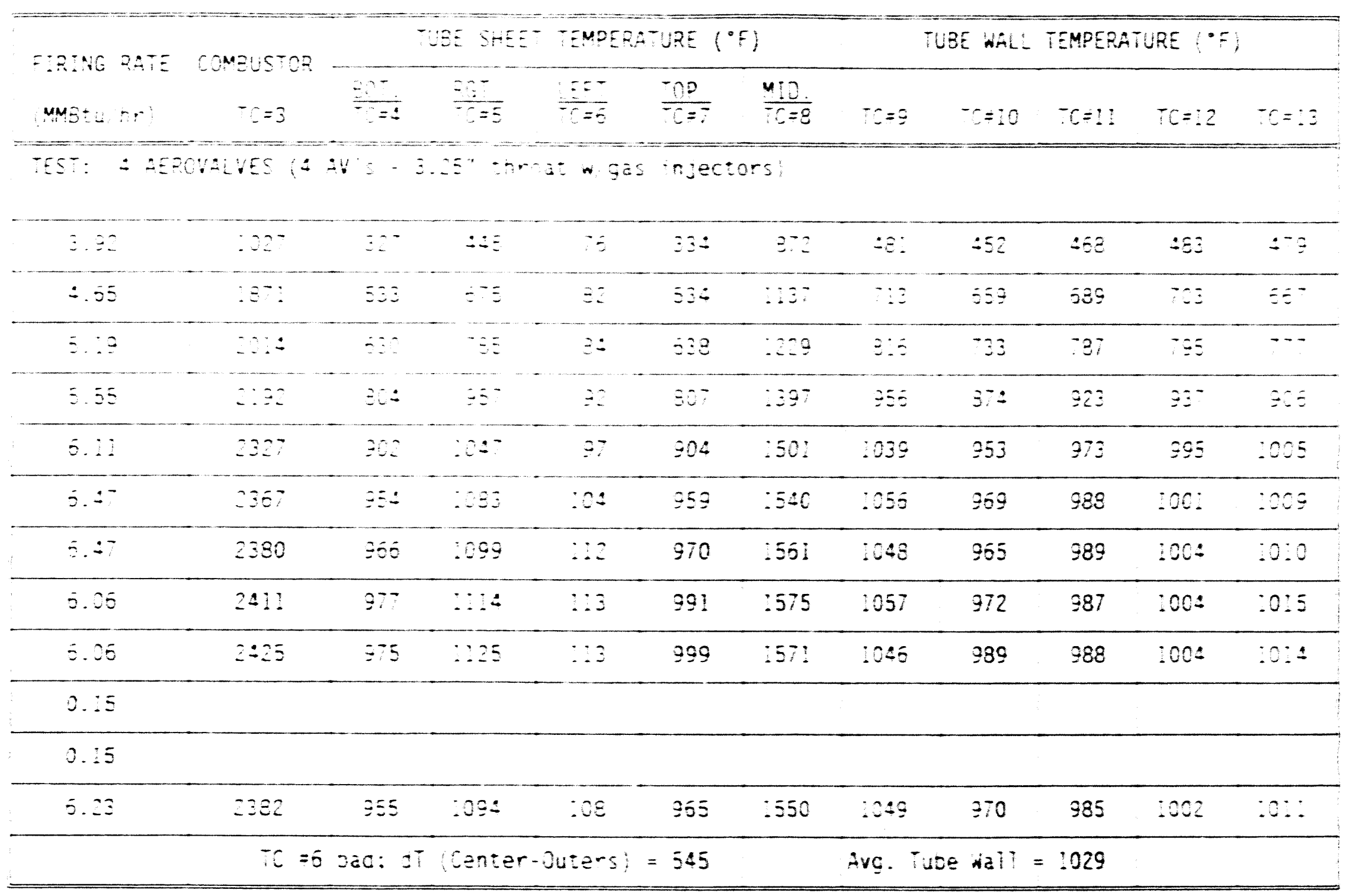


The first configuration consisted of a lwo compartment reactor (see Elgure 5-9). The compartment towards the lealing edge of the pulse heater tubes would be used as a high-temperature, fluid bed gasifier. The colder section would be used for feed drying and prehealing in a low temperature fluid bed.

A shakedown test was run for this conflguration. The test results showed that the design did not perform as expected. The major problem evolved from the mixing of the two bed materials over the partition and bed fluidization. since the two beds were maintalned at two diffuent temperatures, they needed different fluidizing velocity. It was realized that separate fluldization controls are needed which now tends to increase the complexity and cost.

To further investigate the idea, another configuration was tested which included three compartments in the gasifier (IIgure 5 10). The two end sections were to be used as low temperature beds for drying and preheating and the middle one as a high tomperature bed for gasification. A distributed nozzle system was employed to control the fluddization rates of the individual beds. The shakedown tosts with this modifind gasifler furthor reveded the implications of such a scheme. Once agaim. The problem was mathtenance of the bed temperatures, espectally un the couler ides. Ihe tests showed that

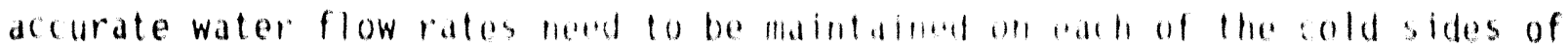
the bed.

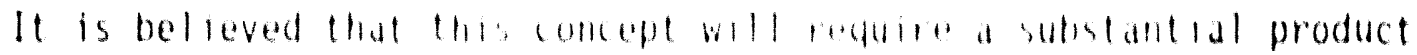
improvement effort and it will therefore not be meluded in the Now Born unit. 


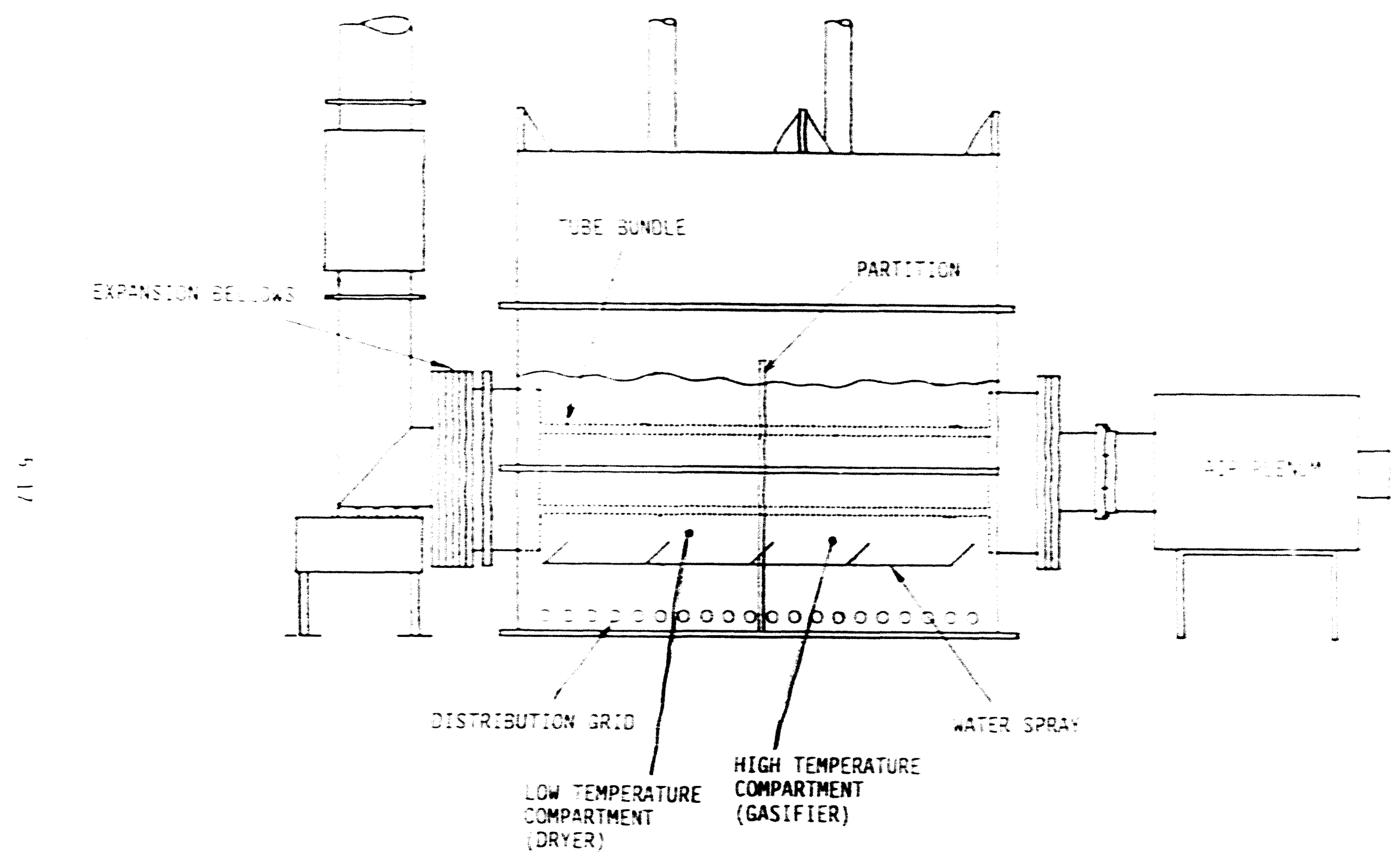

FIGURE 5-9: TWO COMPARTMENT REACTOR VESSEL:

TEST SETUP 


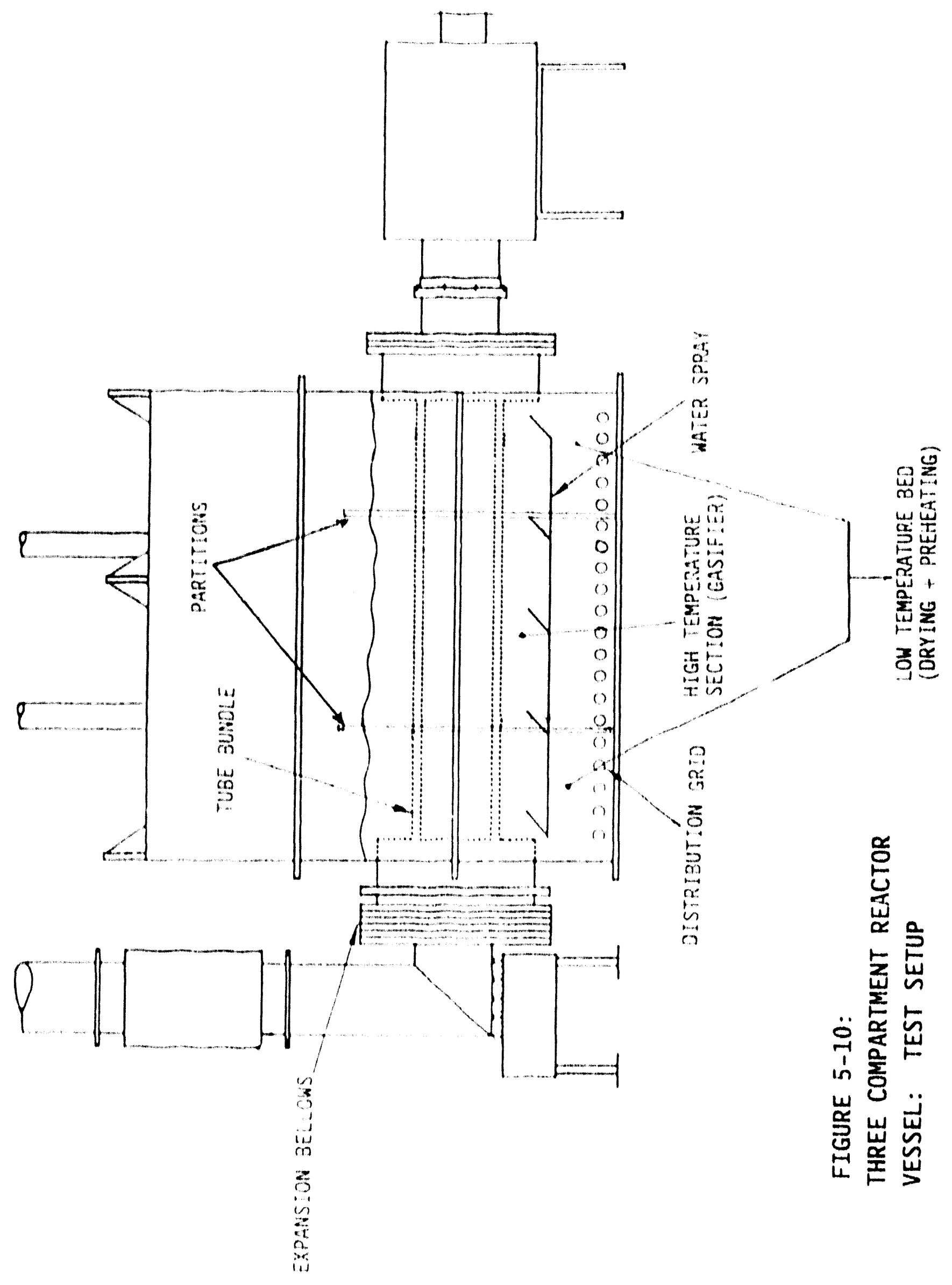




\section{SECTION 6.0 \\ 72-TUBE PULSE HEATER DESIGN}

Based on the information gathered frum the design, development, fabrication and testing of the prototype 61 -tube heater bundle as discussed in the previous section, it was decided to manufacture the field test unit heater bundles in a modular form with each module consisting of 72 pulse tubes. A field test heater bundle unit was designed that included a water-jacketed, refractory-lined combustion chamber, water-couled tube sheets and five aerovalves, each equipped with a gas injectur.

\subsection{DEVELOPMENT BACKGROUND}

An extensive data base from both bench and prototype scales was now available for the pulse combustion heater design. Although the prototype 61 -tube heater module was sufficiently close to the 72 -tube module to be used in the field test unit, the heater performance was evaluated only at the laboratory-scale under simulated conditions. Moreover, the test was performed only for the heater module immersed in a sand bed but without any feed material to be gasified and resulted in an operating temperature of about $850^{\circ} \mathrm{F}$.

The field test unit is intended to operate with black liquor at approximately $1150^{\circ} \mathrm{F}$. The system would therefore require numerous other components such as venturi and caustic scrubbers, an impact separator with heat exchanger, a cyclone, a flare, waste heat boilers, mufflers, etc. Moreover, the field unit would require three to four heater modules. In order to determine the reliability of the heater module under conditions simulating more closely the actual operating conditiuns at New Bern, it was essential that at least one full-size module be field tested under actual hightemperature gasification conditions. In concert with DOE and Weyerhaeuser, it was determined that a paper mill sludge waste would provide a much closer simulation for black liquor processing than the water and sand beds previously used for prototype testing. It was decided to test the module somewhere in the vicinity of the MTCI California facility. Three paper mills were 
interested in hosting the gasification pilot plant. Of the three, namely, Smurfit Newsprint Corporation, Inland Container Corporation (ICC), and Simpson Paper Company, ICC agreed to be the host site. A l-ton per hour gasification pilot was installed at ICC's recycle paper mill site in Ontario, California. One 72-tube heater bundle would be used to gasify 1-ton per hour of wet sludge with a moisture content ranging from 50 to 80 percent.

The gasification of waste sludge differs only slightly from that of black liquor. Sludge gasification is performed at a higher temperature (1300$1500^{\circ} \mathrm{F}$ ) than black liquor $\left(1100-1150^{\circ} \mathrm{F}\right)$ a plus for determining reliability. The fluidized bed for black liquor is comprised of $\mathrm{Na}_{2} \mathrm{CO}_{3}$. Sludge gasification, on the other hand, is carried out with limestone or sand as the bed material. The low melting temperature of $\mathrm{Na}_{2} \mathrm{CO}_{3}$ makes it necessary to avoid high-temperatures at the surface of the pulse tubes to prevent smelt formation and subsequent bed agglomeration. Hence, the tube design for black liquor gasification consists of a radiation shield (Fiqure 6-1) for a portion of the tube length in order to avoid those hot spots. The sludge gasification tube bundle does not require this radiation shield (Figure 6-2) and hence is more convenient to manufacture. It was also possible that good temperature control of the bed and tubes would permit eliminating the radiation shields. It should be noted that the overall performance of the unit will differ only slightly from the earlier prototype, primarily with respect to heat transfer. Therefore, the performance of the new heater bundle for sludge gasification will be well representative of its performance under black liquor gasification conditions. Moreover, the 61-tube prototype heater bundle contained radiation shields, the performance characteristics of which have already been established.

\subsection{2-TUBE PULSE HEATER BUNDLE MODULE}

The 72-tube pulse heater bundle module (Figures 6-3) consists of a waterjacketed refractory-lined cylindrical combustion chamber. The inner surfaces of the chamber are lined with 2 -inch refractory on the cylindrical surface and $3-\frac{1}{4}$ inch on the flat surface adjacent to the tube sheets. The refractory is temperature cured in a curing oven for over 117 hours and up to $1800^{\circ} \mathrm{F}$. The outer cylindrical surface of the chamber and the space between the tube sheets 


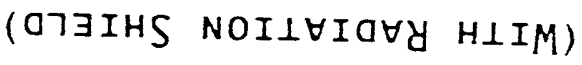

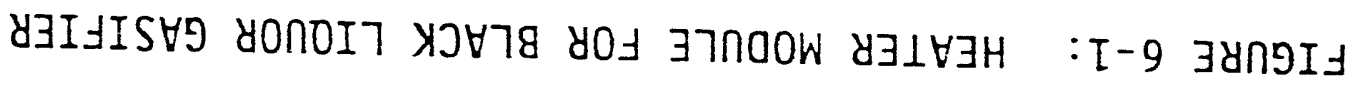

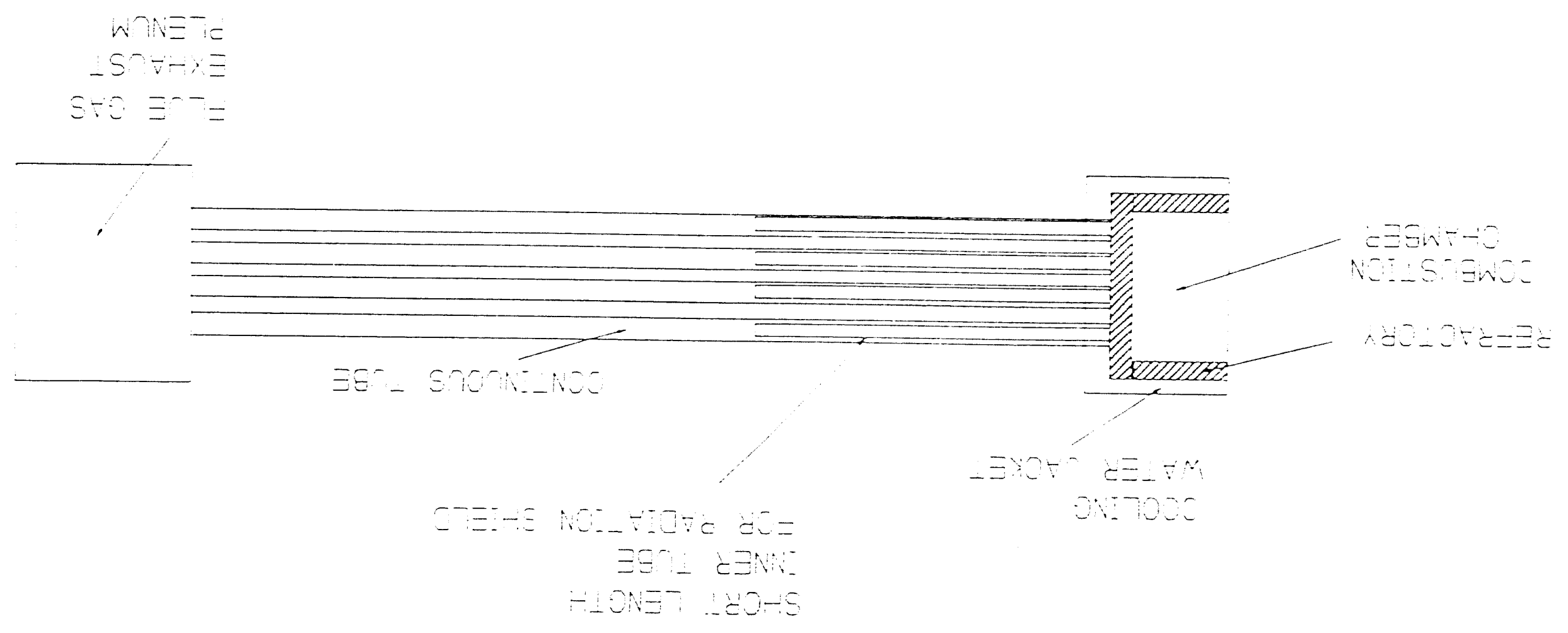




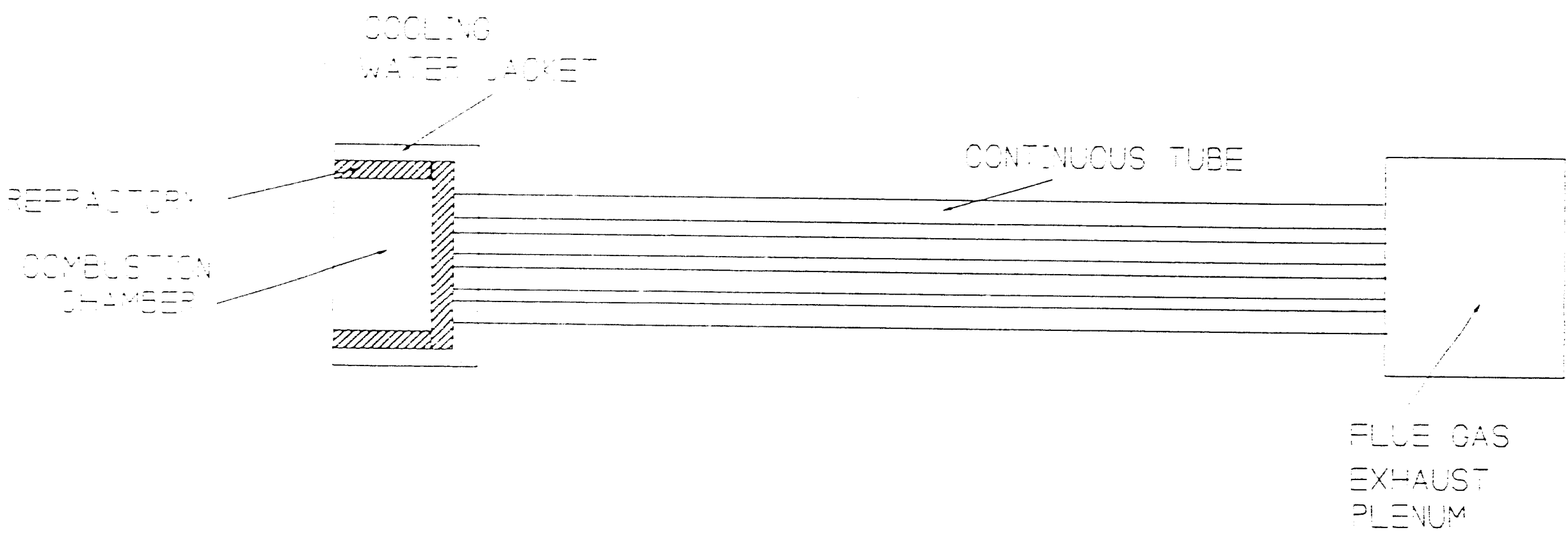

FIGURE 6-2: HEATER MODULE WITHOUT RADIATION SHIELD 

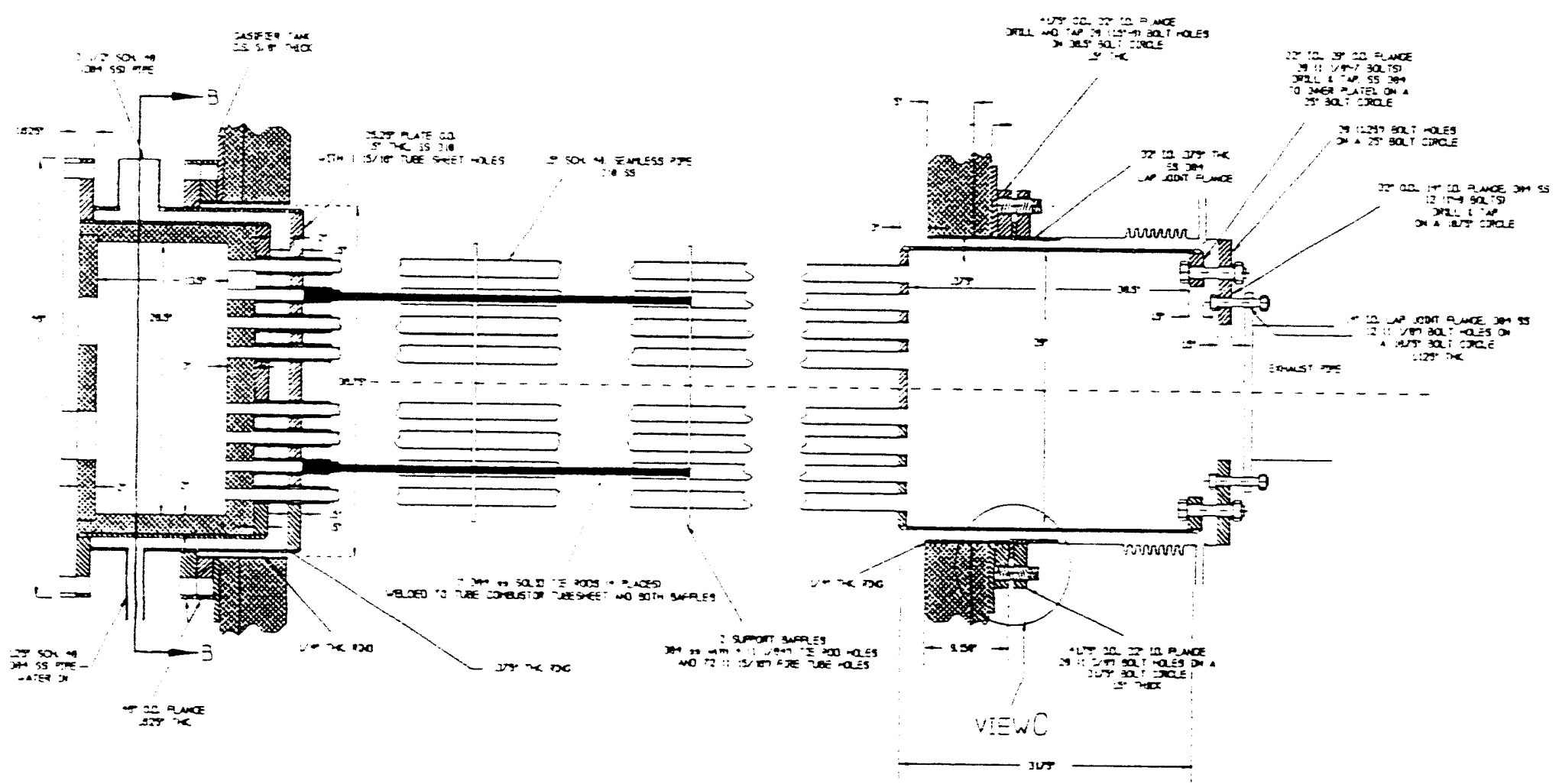

FIGURE 6-3: 72-TUBE HEATER BUNDLE ASSEMBLY 
is water-cooled as shown in Figure 6-3. The combustion chamber is flanked on the front side by a gas manifold chamber (Eigure 6 4). The manifold chamber consists of five 3.68-inch diameter, 8-inch lung aerovalves, each provided with a gas injector with $\frac{1}{4}$-inch diameter orifice inserted into the base of the chamber which is also refractory-lined on the outer surface. The chamber is provided with an ignition pilot for prefiring and preheating of the combustion chamber. Air is provided by a forced draft fan through a muffled air plenum as shown in Figure $5-2$.

The pulse tubes are connected to the tube sheet in a hexagonal arrangement with no pulse tube at the center (Figure 6-5). This design modification was made based on the test with the 6l-tube module in which bowing of the tube sheet was postulated to be a result of the center tube operating at a higher temperatuie than the surrounding tubes. The tailpipes of the pulse tubes are connected to another tube sheet followed by an exhaust plenum.

\subsection{LABORATORY TESTING OF THE HEATER MODULE}

A series of initial tests was conducted to study the combustion, pulsation and acoustic characteristics of the heater module. There were a number of modifications incorporated during the bundle definition tests at the laboratory and are mentioned here along with the test description.

The tests were conducted by inserting the heater bundle into a pressure test vessel (Figure 6-6). The test vessel is also used for leak testing the tube bundle. The test setup is shown in Figure 6-7. The setup consists of a forced draft fan, air plenum, combustion chamber, heater bundle immersed in water inside a pressure vessel, exhaust plenum, waste heat boiler, muffler and stack. The hot combustion flue gases enter the pulse tubes and heat the water inside the vessel. The water-steam mixture generated is collected in a drum before venting the steam to the atmosphere. The cooled flue gases enter the waste heat boiler through the exhaust plenum where the generated steam is vented to the atmosphere. The flue gases then enter the muffler where the pulsations are further muffled, resulting in further cooling of the gas. The cooled gases are then vented to the atmosphere. 


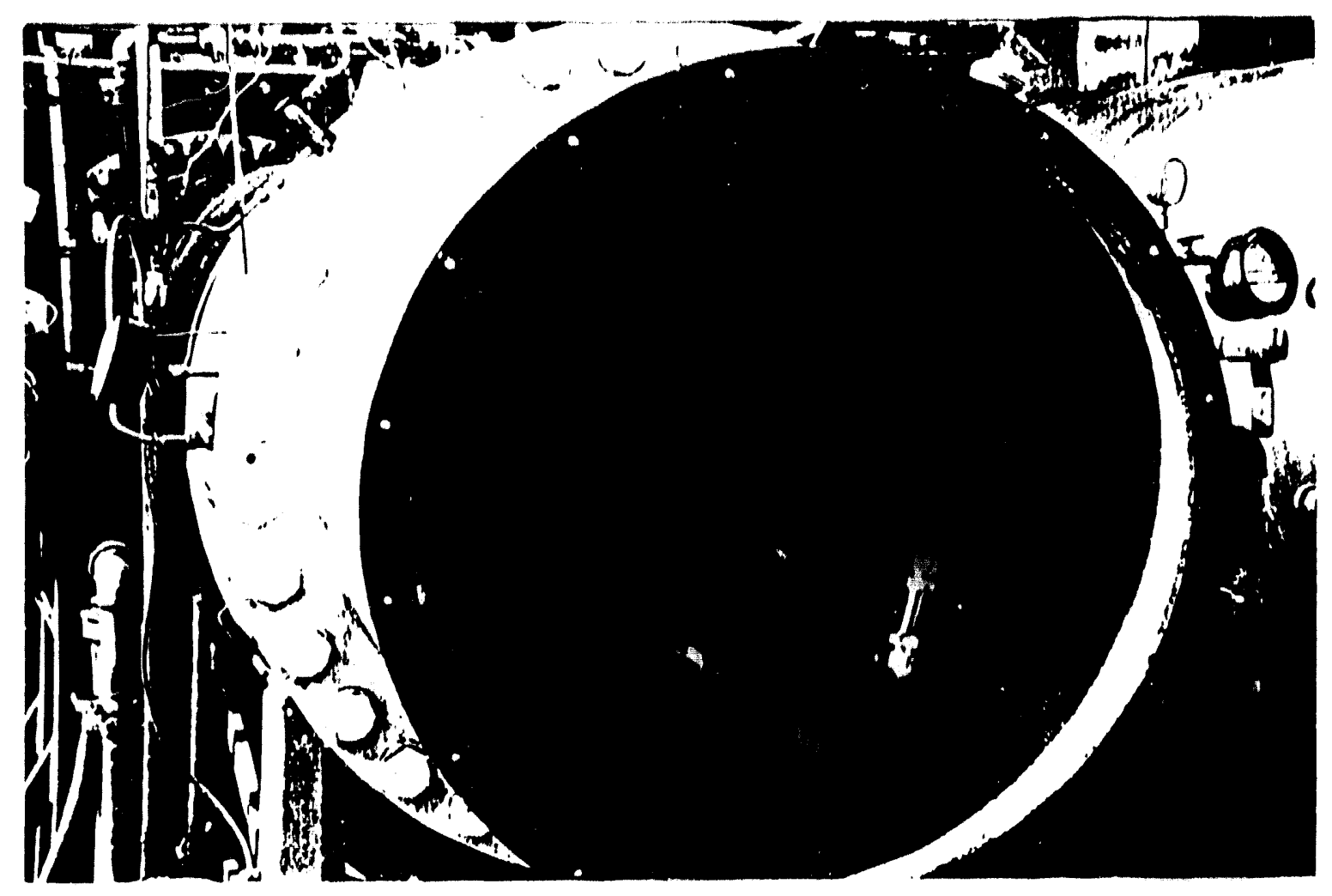

FIGURE 6-4: 72-TUBE HEATER: WATER JACKETED AND REFRACTORYLINED COMBUSTION CHAMBER AND TUBE SHEET 


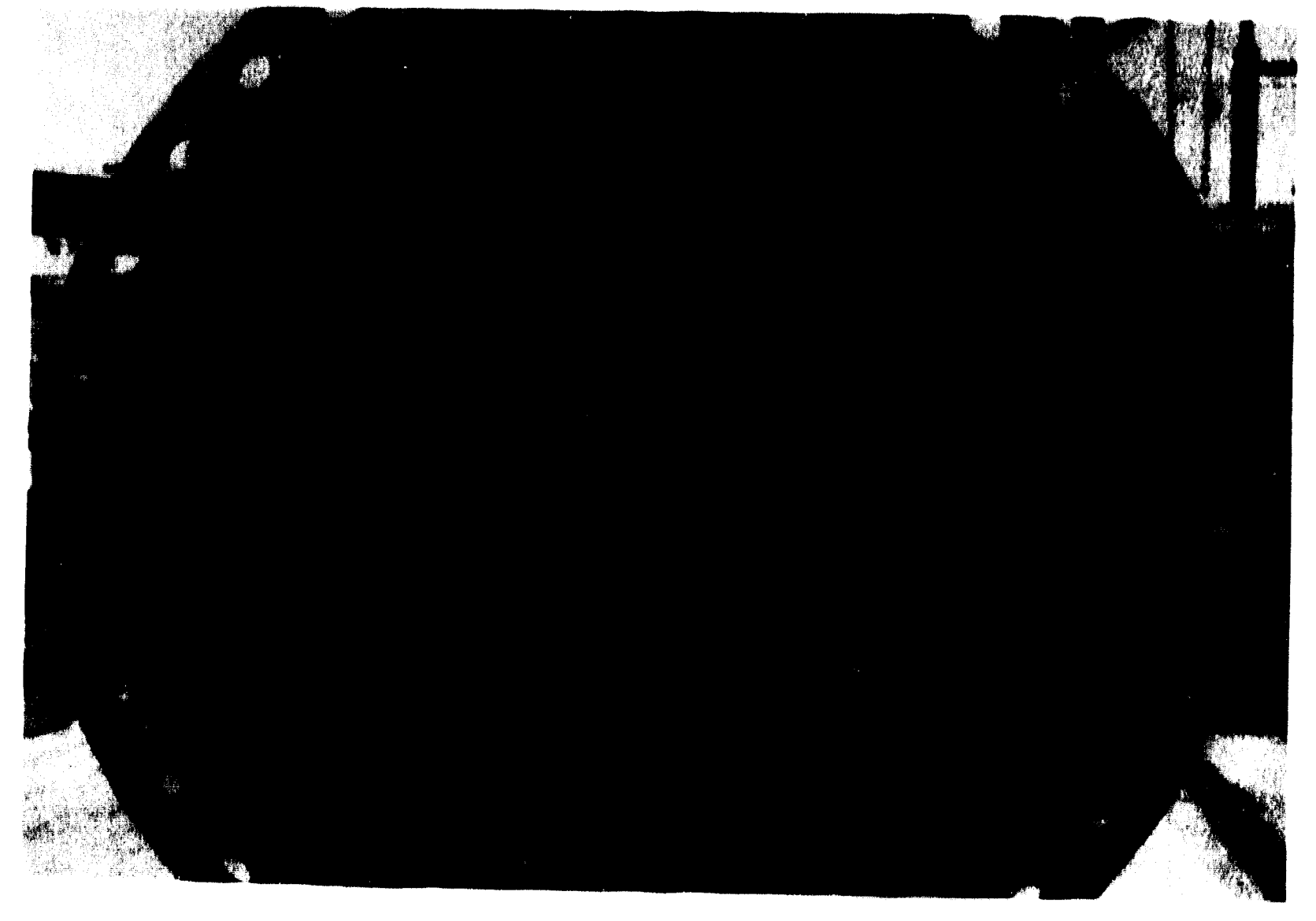

FIGURE 6-5: HEXAGONAL ARRANGEMENT OF TUBE BUNDLES 


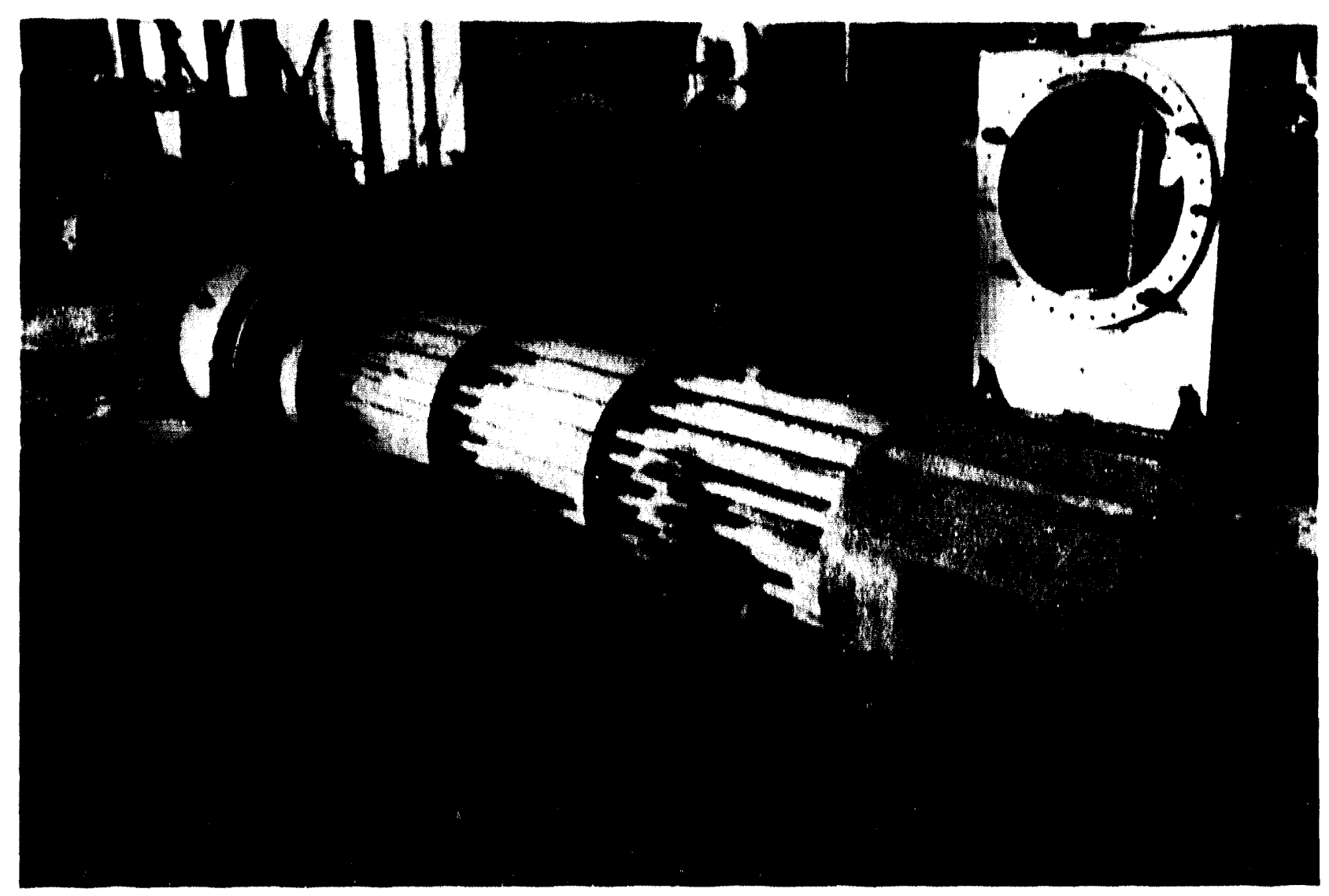

FIGURE 6-6: PULSE HEATER AND PRESSURE TEST VESSEL 


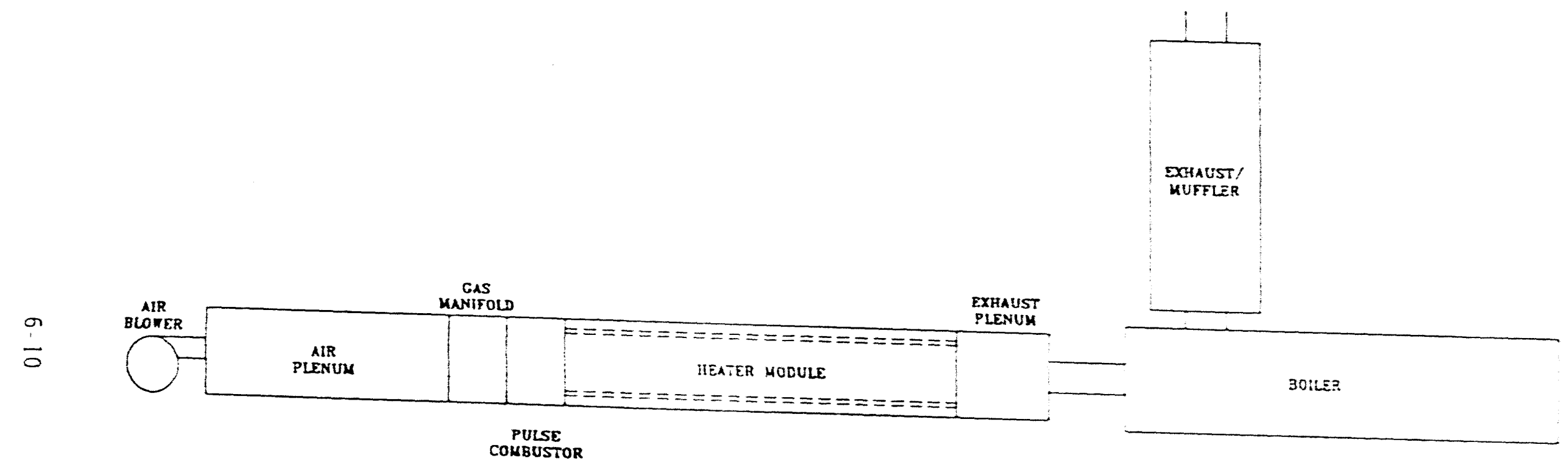

FIGURE 6-7: SCHEMATIC OF LABORATORY TEST SETUP 
The initial test setup did not have a waste heat boiler or a muffler, resulting in loud pulsations. The introduction of the waste heat boller together with a final muffler design eliminated these acoustic vibrations almost completely as shown by later test results. The description of the waste heat boiler and the muffler are described in the next section.

\subsection{TEST RESULTS}

Several laboratory test runs were conducted over a period of 3 months to obtain and study the characteristics of the 72 -tube heater module.

lables 6-1 through 6-6 show the consolidated results from these tests.

The first shakedown test was run on August 30, 1991 for firing rates ranging from 1.9 to 7.4 million Btu/hr. The peak to peak combustion pulsation pressure was observed to be approximately $2.6 \mathrm{psi}$ at approximately $60 \mathrm{~Hz}$ frequency. A hand held decibel meter showed a very higit A-weighted sound pressure level of approximately $120 \mathrm{~dB}$ (at $3.7 \times 10^{\circ} \mathrm{Btu} / \mathrm{hr}$ firing rate) near the exhaust stack. The noise level was higher for higher firing rates. The information is summarized in lable $6-1$.

As can be seen from the table, the combustion chamber temperature was well below the calculated adiabatic temperature partly because of the fact that in pulse combustion the gases are only partially combusted and the combustion continues in the tubes. The other reason is the location of the thermocouple in the combustion chamber. It could only be located a few inches awa. from the refractory and hence could not provide accurate temperature. A sheath thermoccuple was used in the next test and a better temperature reading was obtained, as shown in lable 6-2. This test also utilized a stack muffler and the noise level dropped down to about $117 \mathrm{~dB}$ at $3.7 \times 10^{6} \mathrm{Bt}$.u/hr firing rate. An improved muffler design would reduce this even further.

An industry survey revealed that a muffler meeting on our noise reduction requirements was not commercially available due to the temperature and low frequency pressure oscillations of the pulse combustion system. A rigorous design effort was undertaken to design and fabricate one in-house. To reduce the cost of muffler fabrication, a used waste heat boiler (rated $4 \mathrm{MMBtu} / \mathrm{hr}$ at 
TABLE G-1: DATA IND RESULTS =OR 3:30/9: IEST RUN

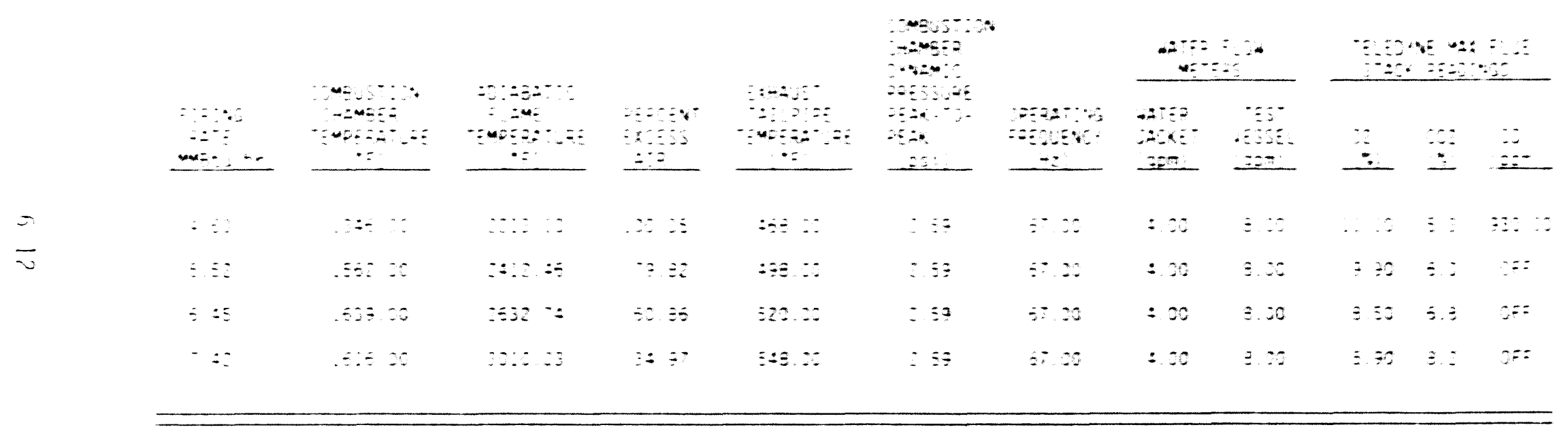




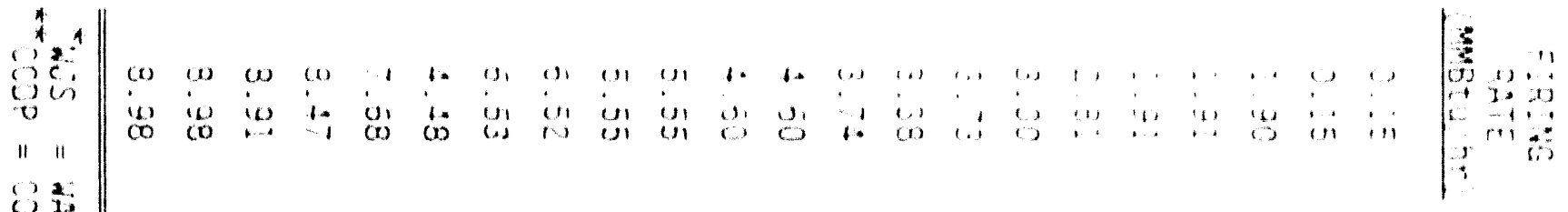

$\sum_{\substack{1 \\ C_{0}}}^{2}$

$\sum_{\substack{n \\ i=1}}$

?a.

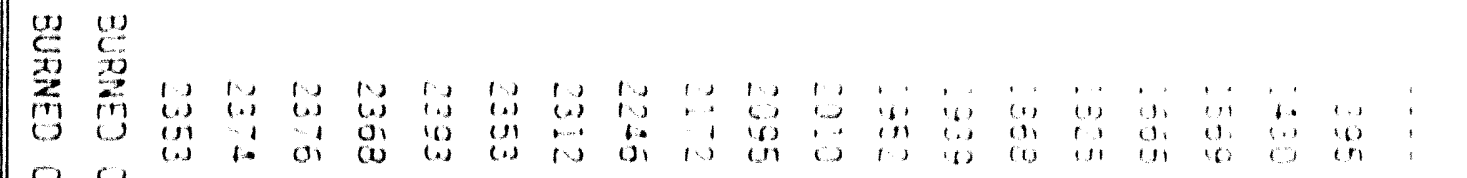
$2 巳$

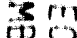
$\sum_{-1}$

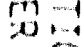

是

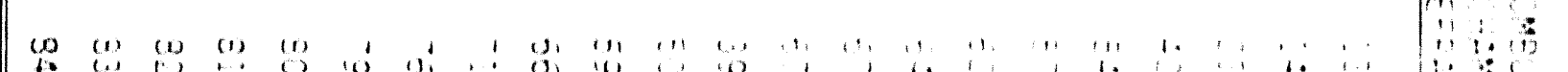

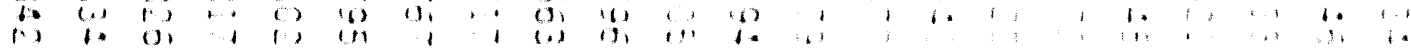

(․)

(20)

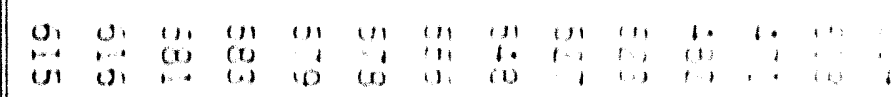

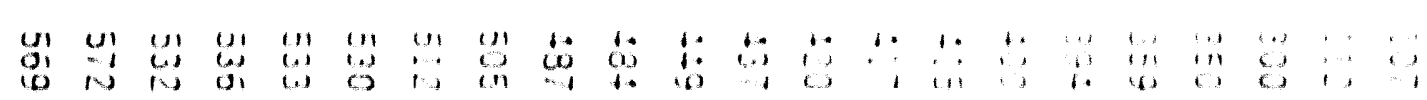

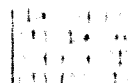

(1)

2.

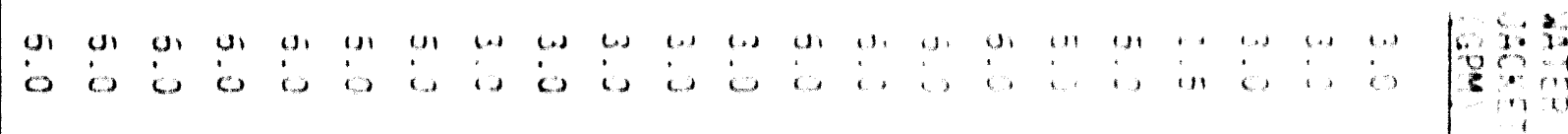

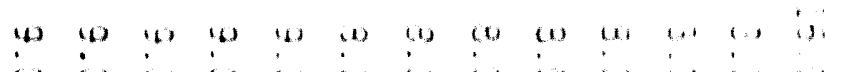

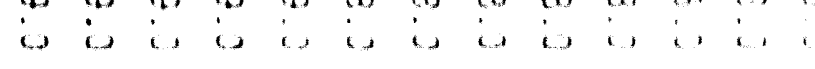

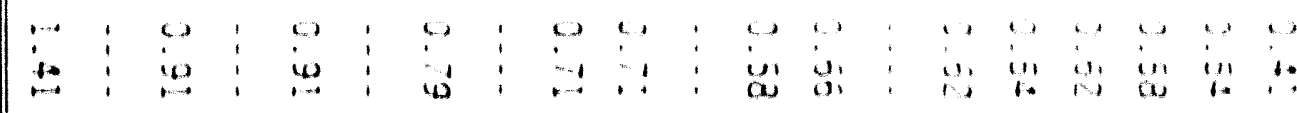

(1)

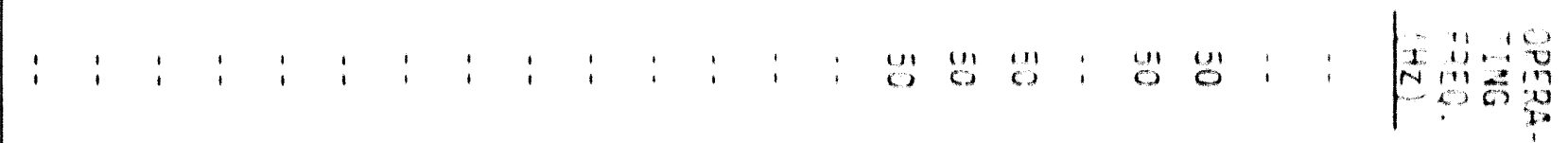

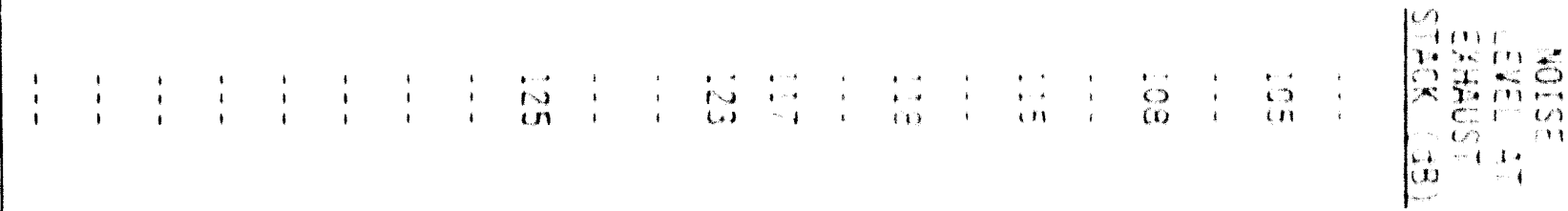

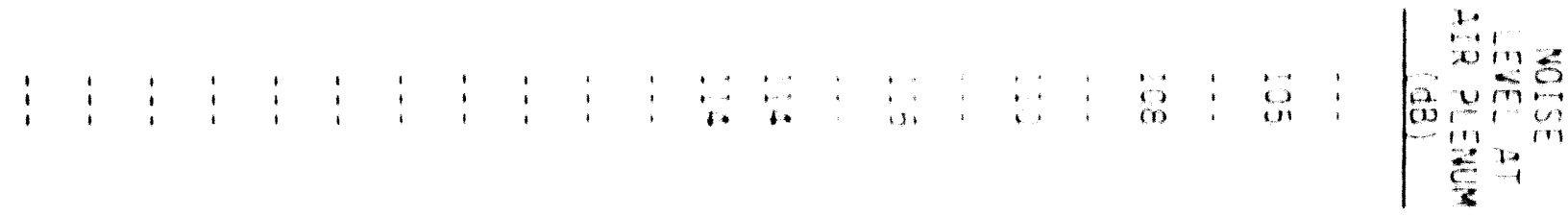




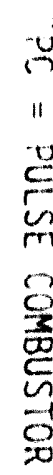

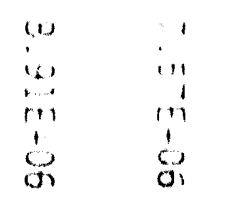

$\cdots$
$\vdots$
$\vdots$
$\vdots$
$\vdots$

$\frac{1 .}{\vdots}$

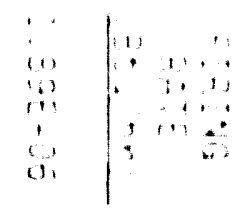

का 10 or on

men

waw

$\because: 3$

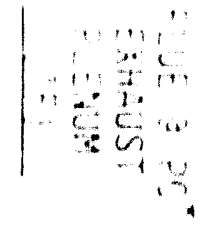

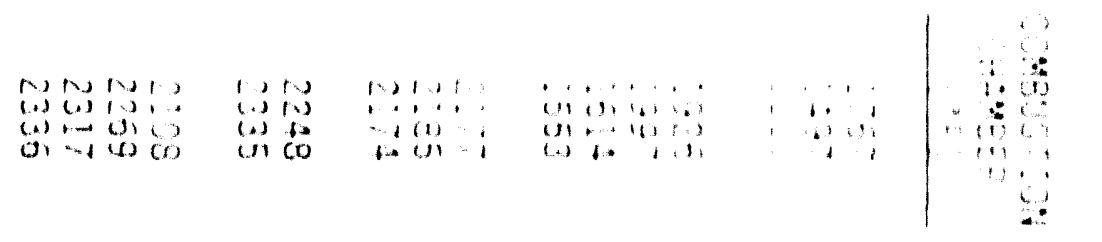

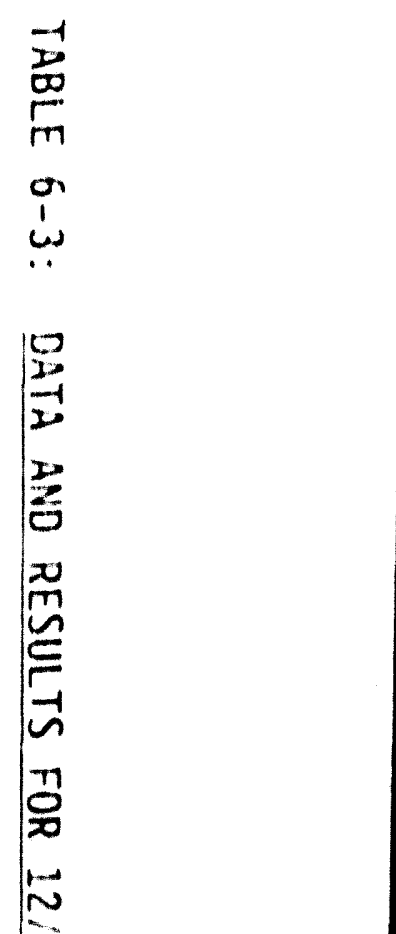

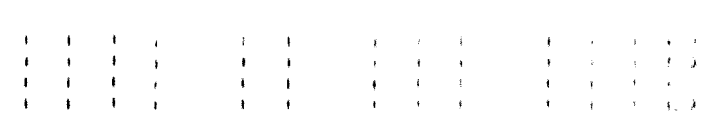

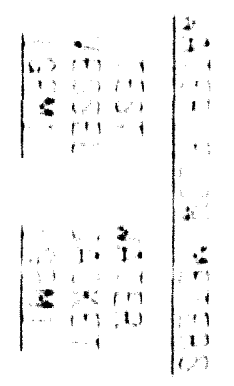

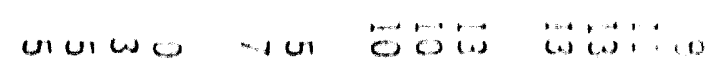

is is in on a to thin

i.: : : :

$\mid 20$

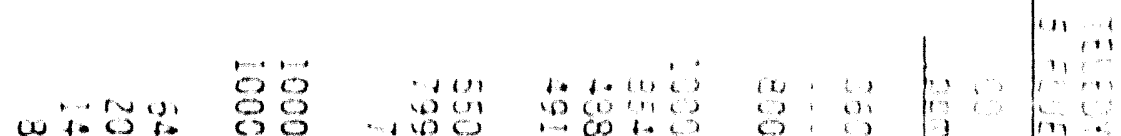

ш

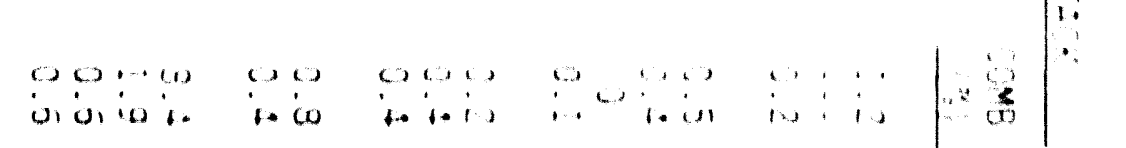

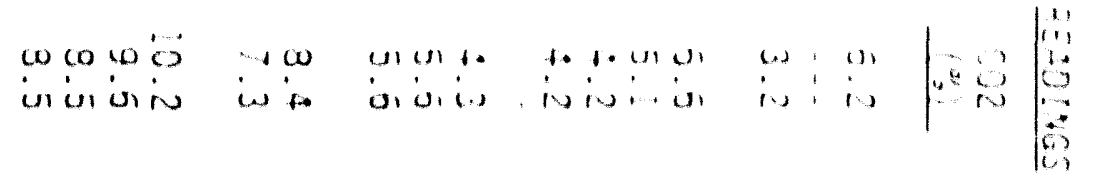

$\frac{10}{2}$

蕉

용

in

$\infty$

倠

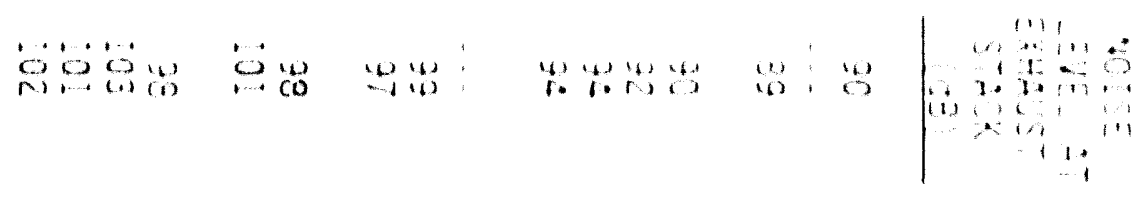

舟是是是 


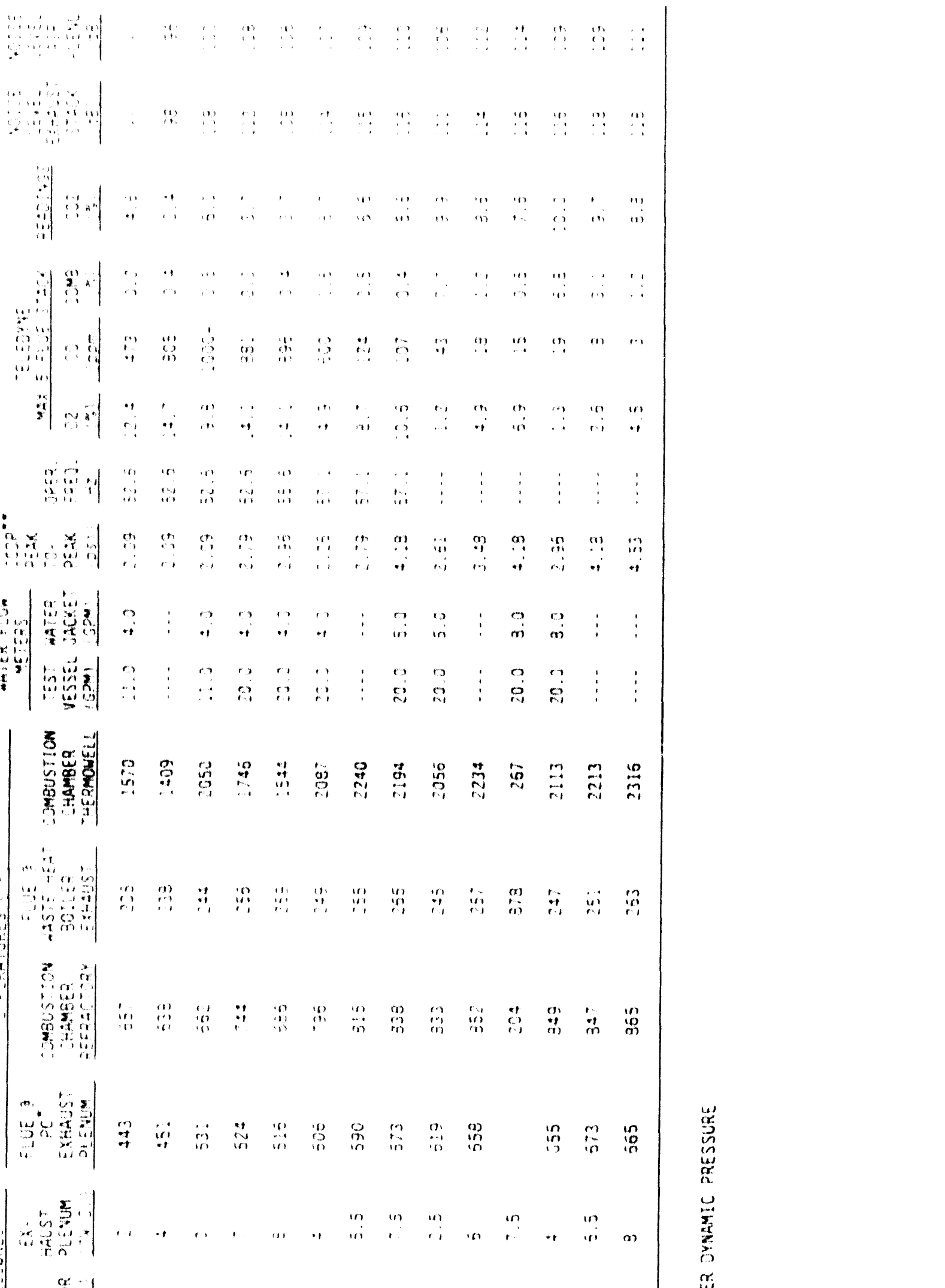

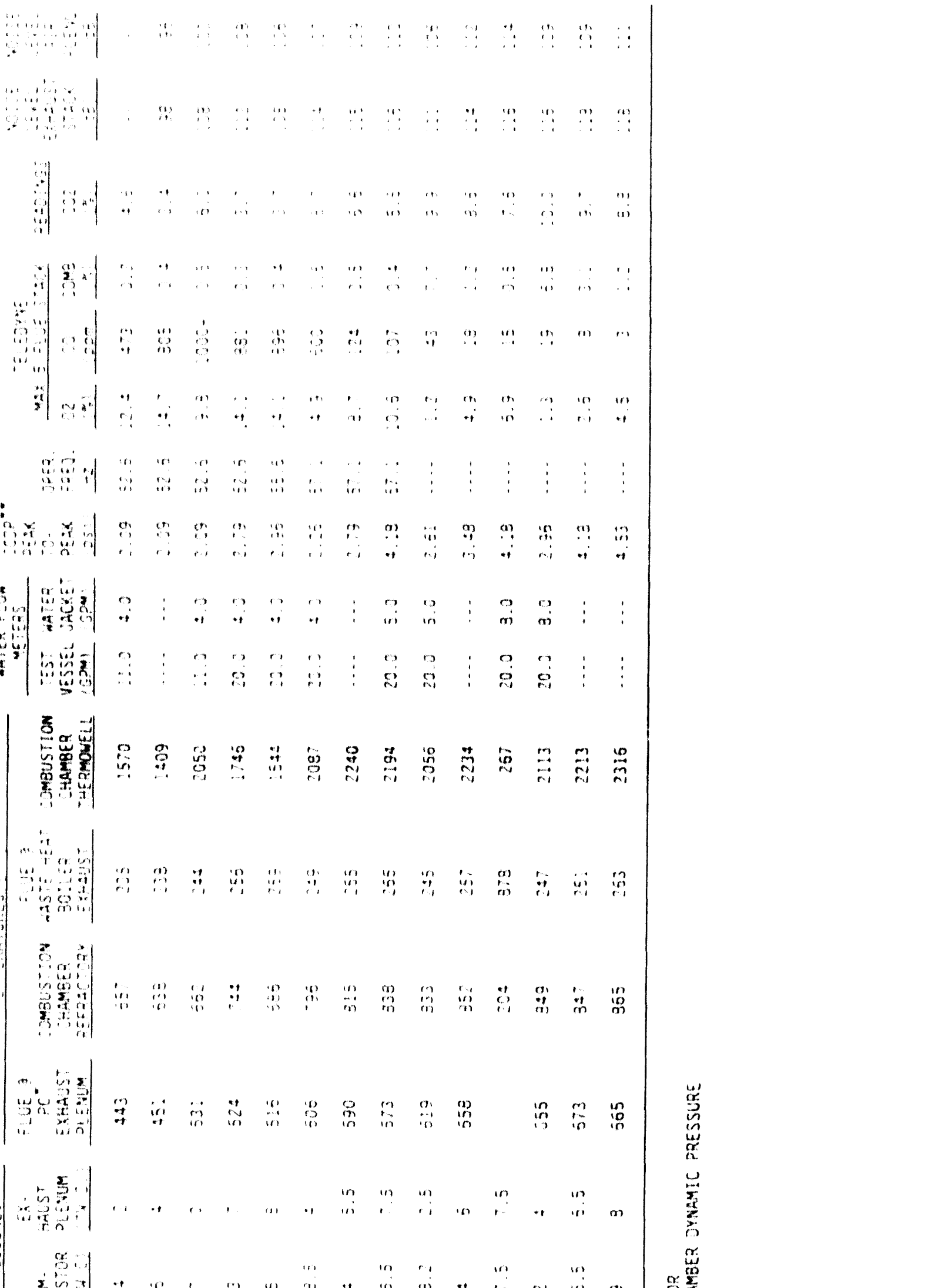

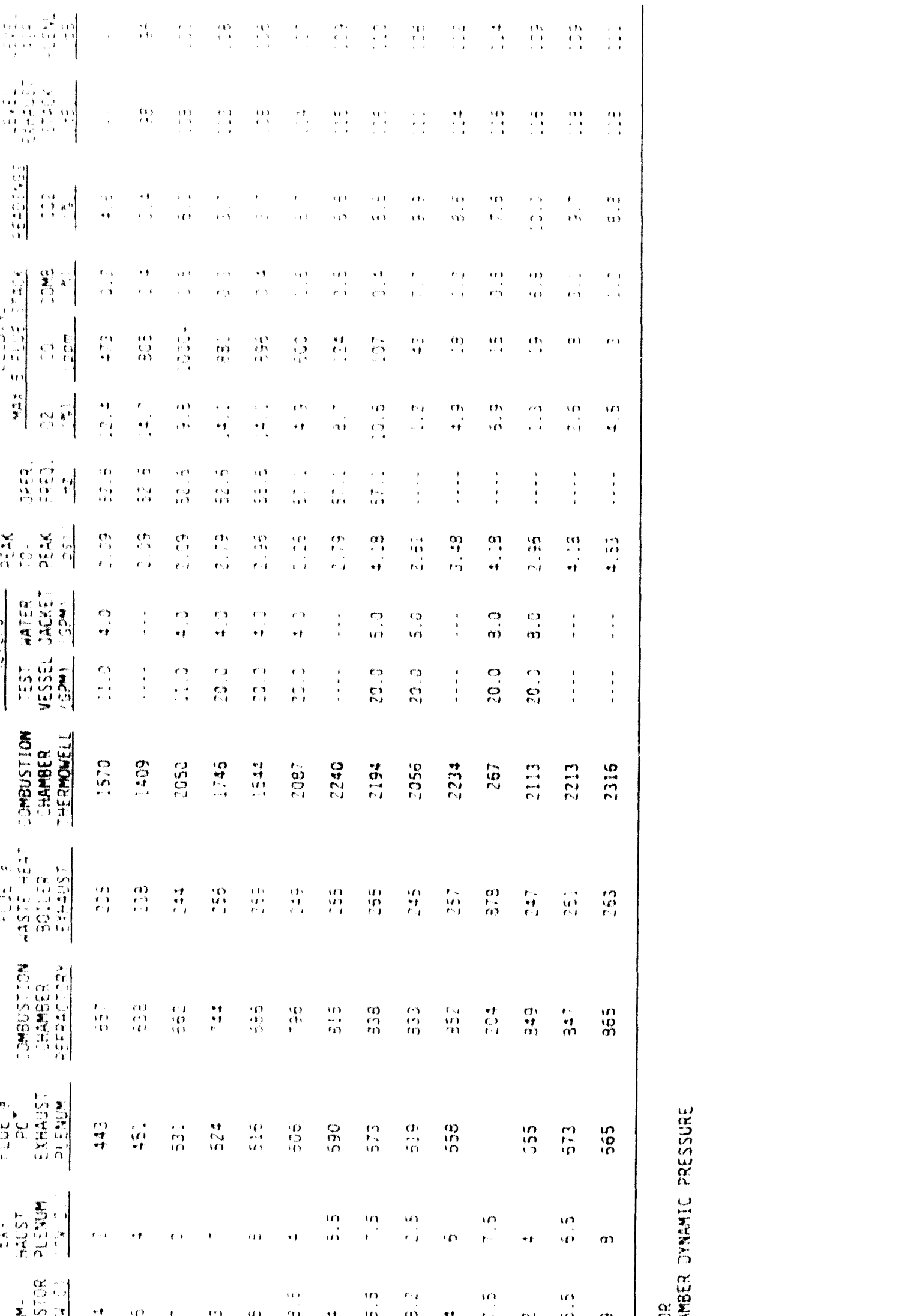

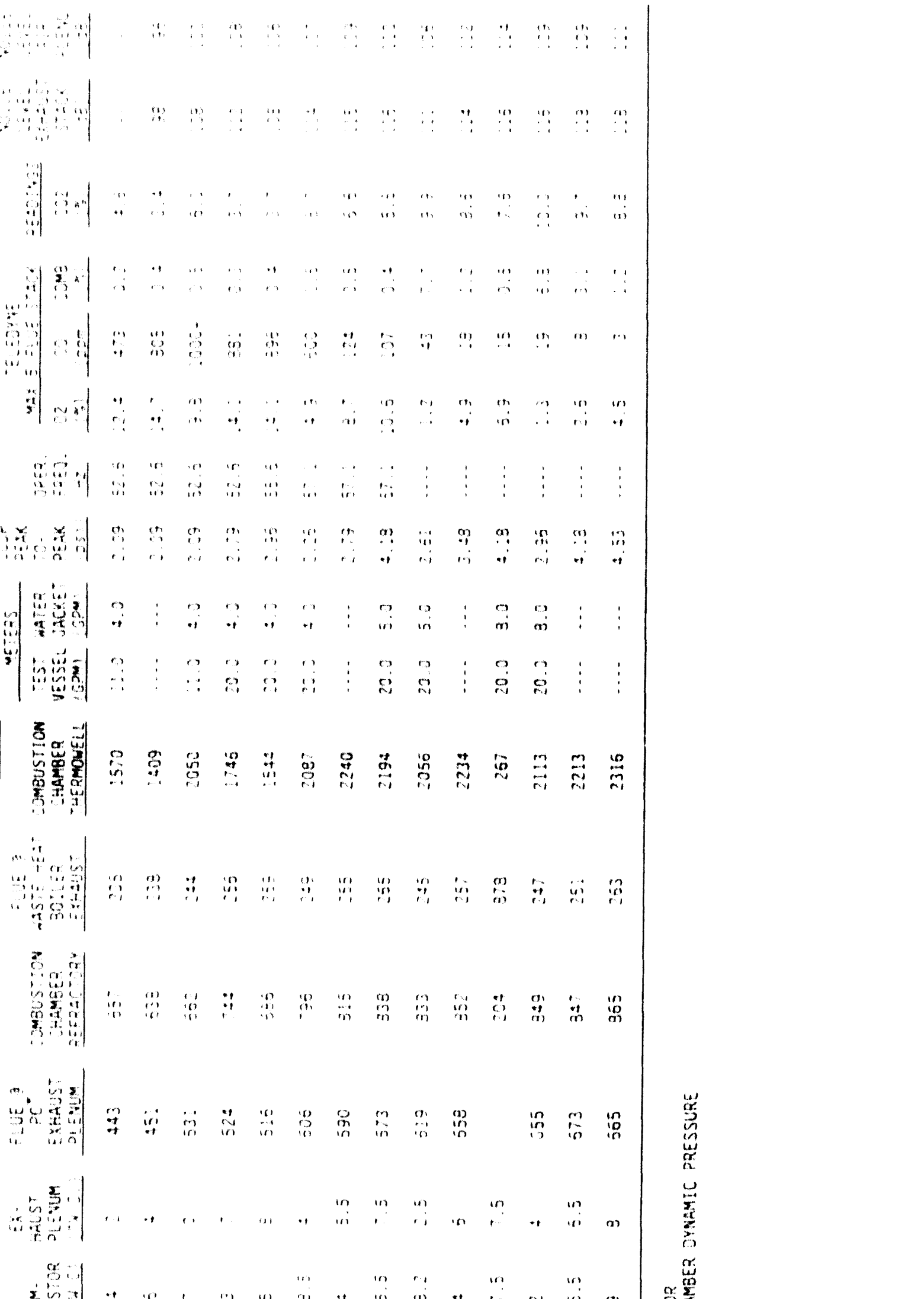

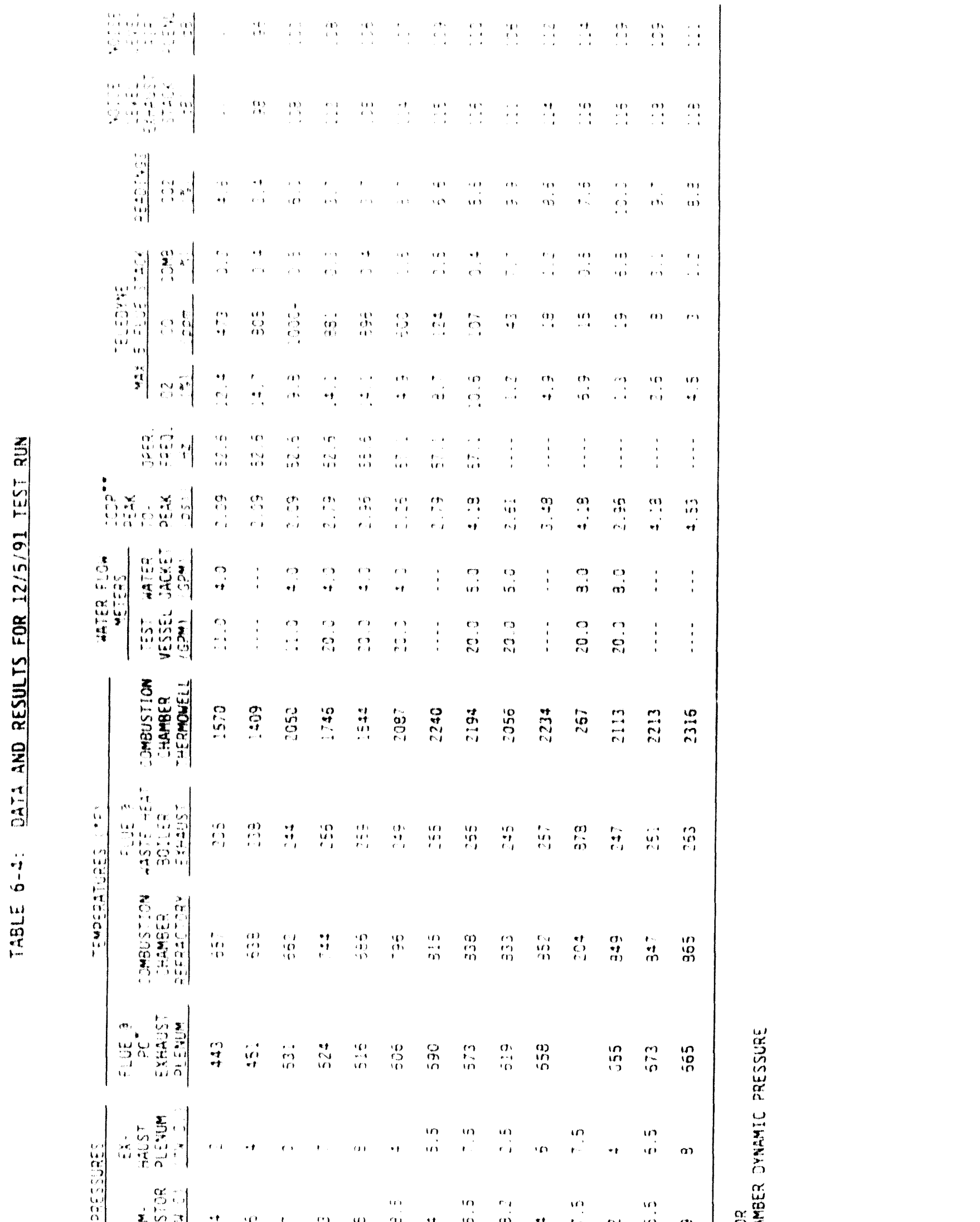

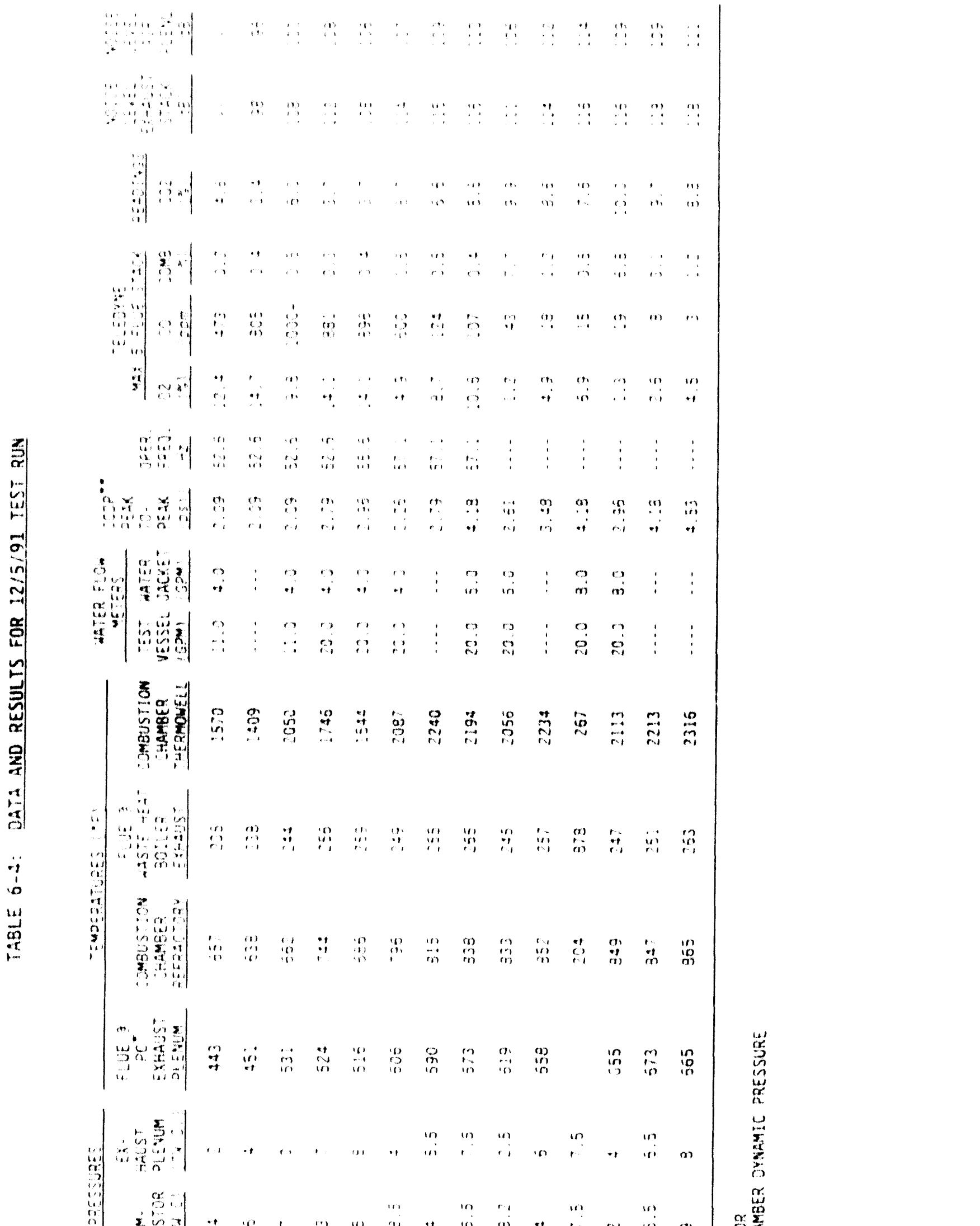

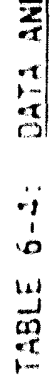

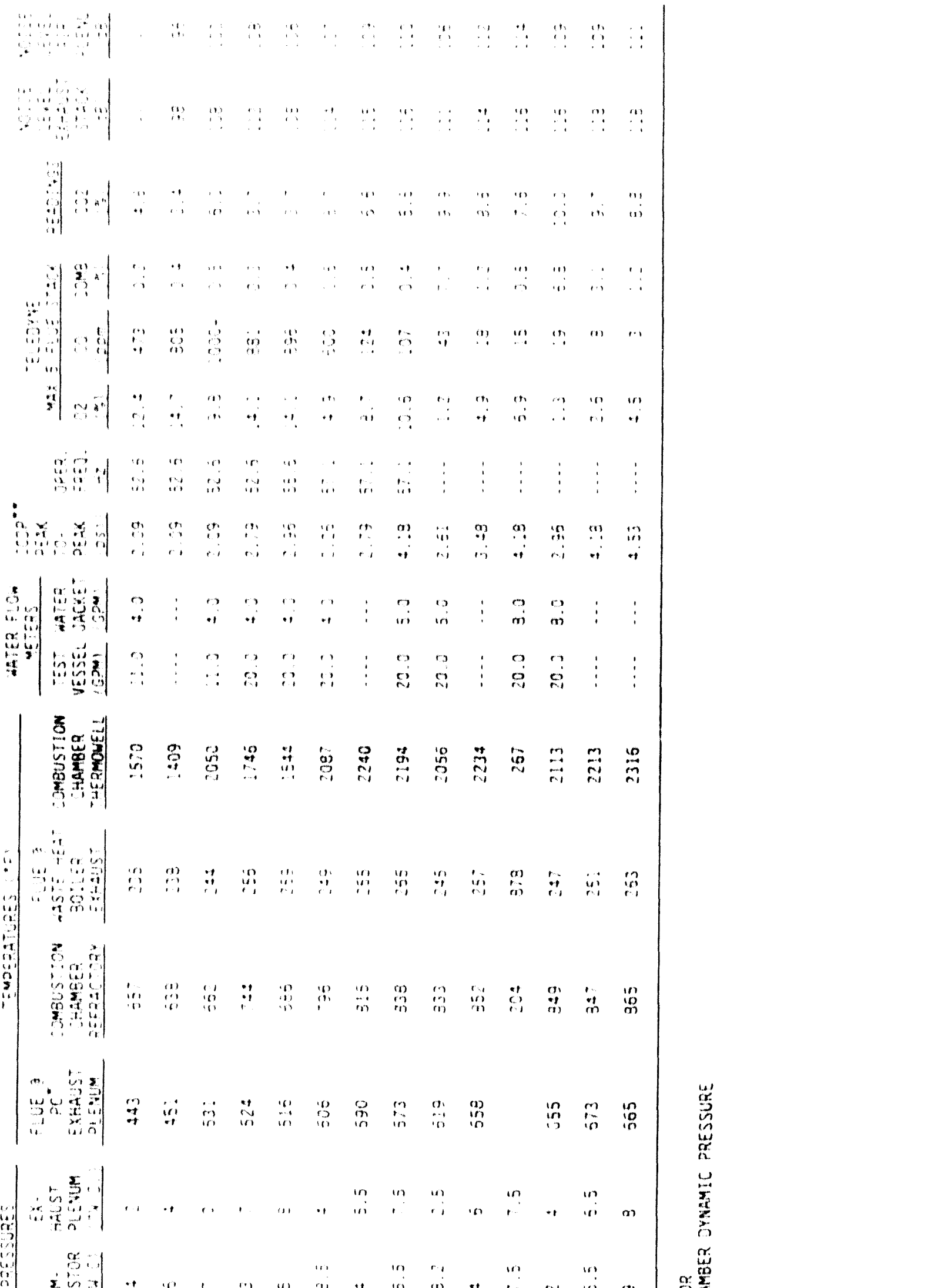

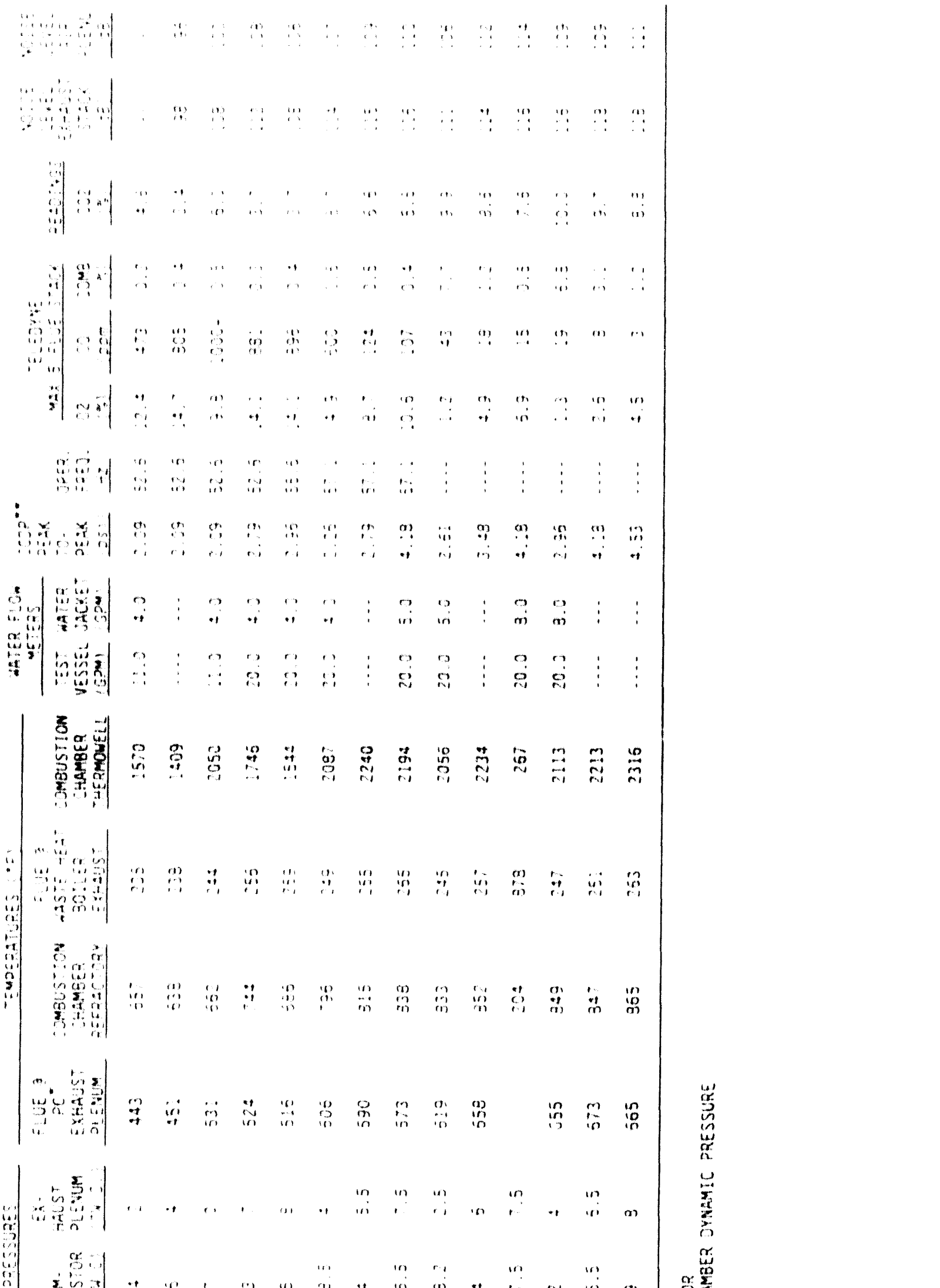

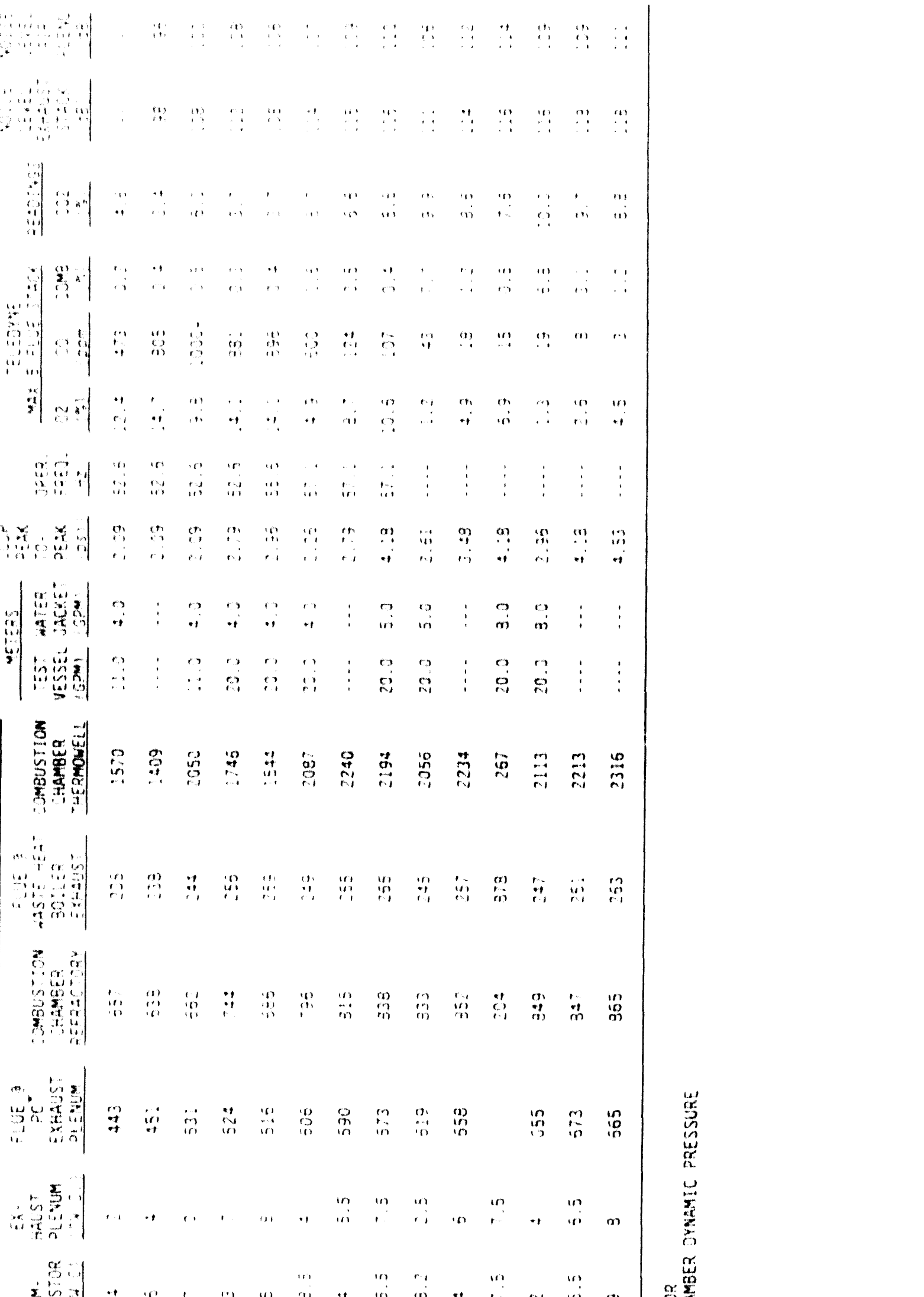

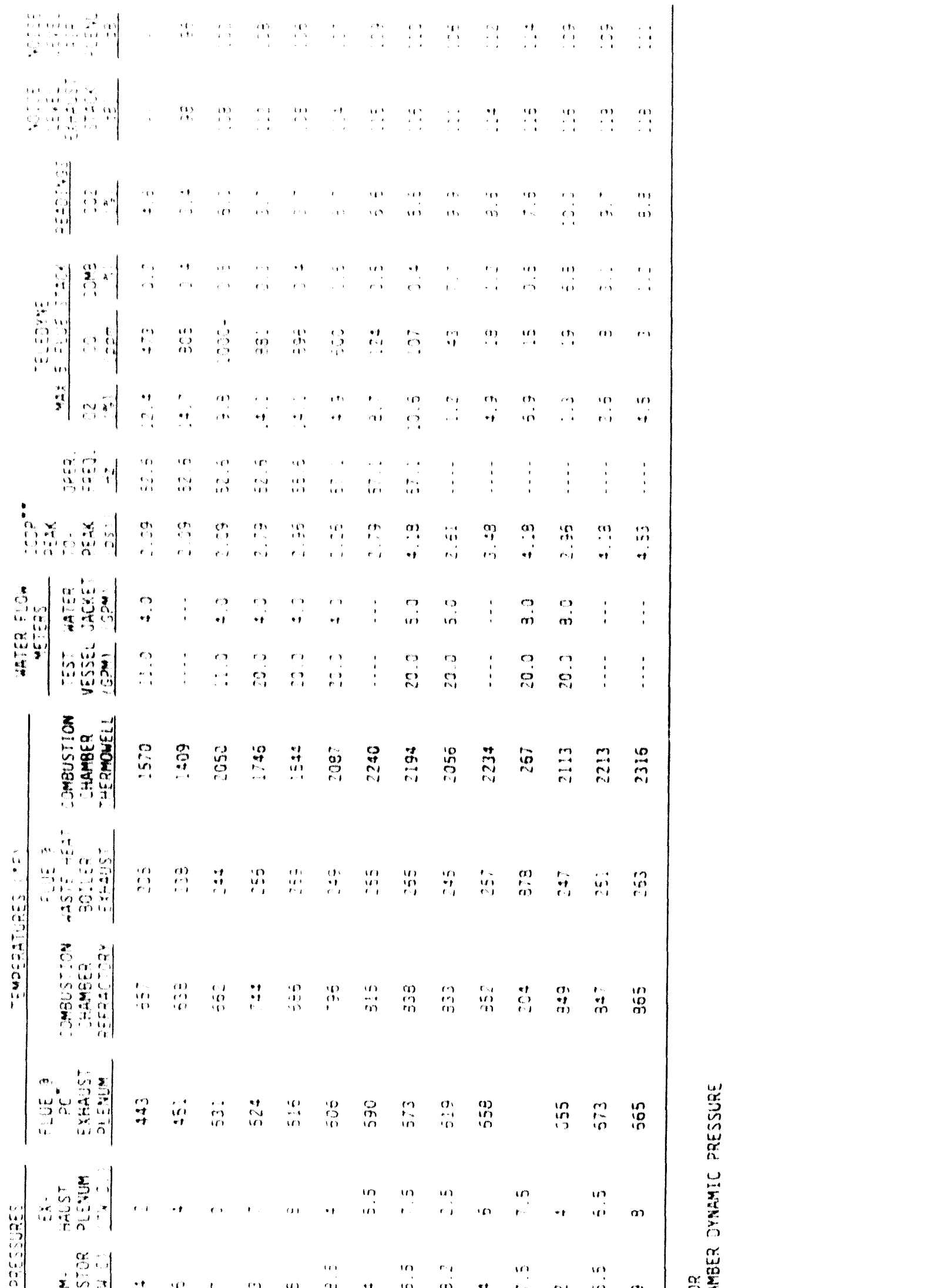

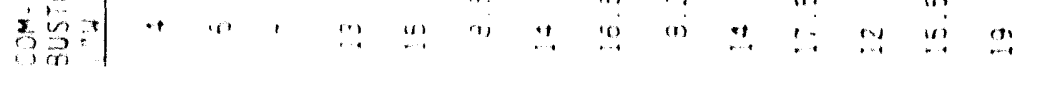

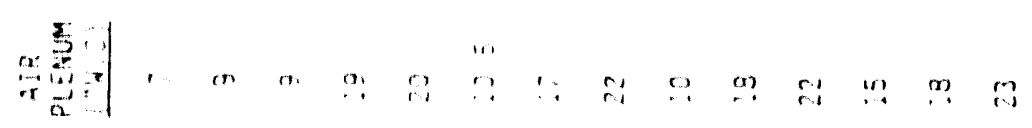

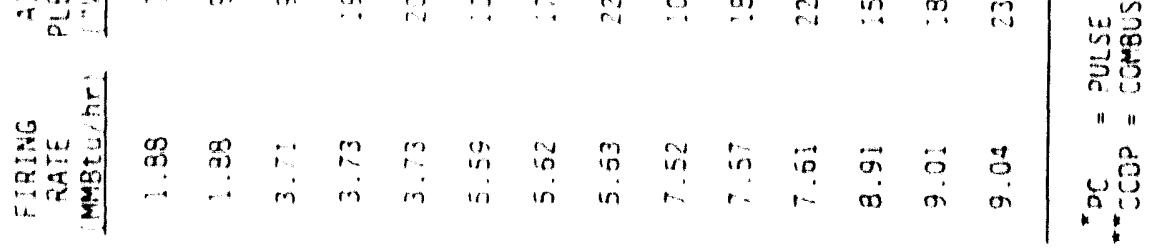


TABLE 6-5:

COMPARISON OF NOISE LEVELS

WITH TWO DIFFERENT AEROVALVES

\begin{tabular}{|c|c|c|c|c|c|c|c|}
\hline \multicolumn{4}{|c|}{$\begin{array}{l}\text { AEROVALVE THROAT DIAMETER }=3.68^{\prime \prime} \\
\text { (December 4, 1991) }\end{array}$} & \multicolumn{4}{|c|}{$\begin{array}{c}\text { AEROVALVE THROAT DIAMETER }=3.25^{\prime \prime} \\
(\text { December 4, 1991) }\end{array}$} \\
\hline $\begin{array}{l}\text { FIRING } \\
\text { RATE } \\
\text { (MMBtu/hr) } \\
\end{array}$ & $\begin{array}{l}\% \\
02 \\
\end{array}$ & $\begin{array}{l}\text { EXHAUST } \\
\text { PLENUM } \\
(\mathrm{dB}) \\
\end{array}$ & $\begin{array}{c}\text { AIR } \\
\text { PLENUM } \\
(d B) \\
\end{array}$ & $\begin{array}{c}\text { FIRING } \\
\text { RATE } \\
\text { (MMBtu/hr) }\end{array}$ & $\begin{array}{l}\% \\
02 \\
\end{array}$ & $\begin{array}{l}\text { EXHAUST } \\
\text { PLENUM } \\
(\mathrm{dB}) \\
\end{array}$ & $\begin{array}{l}\text { AIR } \\
\text { PLENUM } \\
(\mathrm{dB}) \\
\end{array}$ \\
\hline 3.71 & 13.2 & 94 & 91 & 3.73 & 14.1 & 108 & 108 \\
\hline 5.62 & 10.7 & 99 & 93 & 5.63 & 10.6 & 116 & 110 \\
\hline 7.75 & 7.6 & 101 & 97 & 7.57 & 6.9 & 116 & 114 \\
\hline 8.91 & 3 & 103 & 95 & 9.01 & 2.6 & 118 & 109 \\
\hline 8.91 & 5.2 & 101 & 98 & 9.03 & 4.5 & 118 & 111 \\
\hline
\end{tabular}




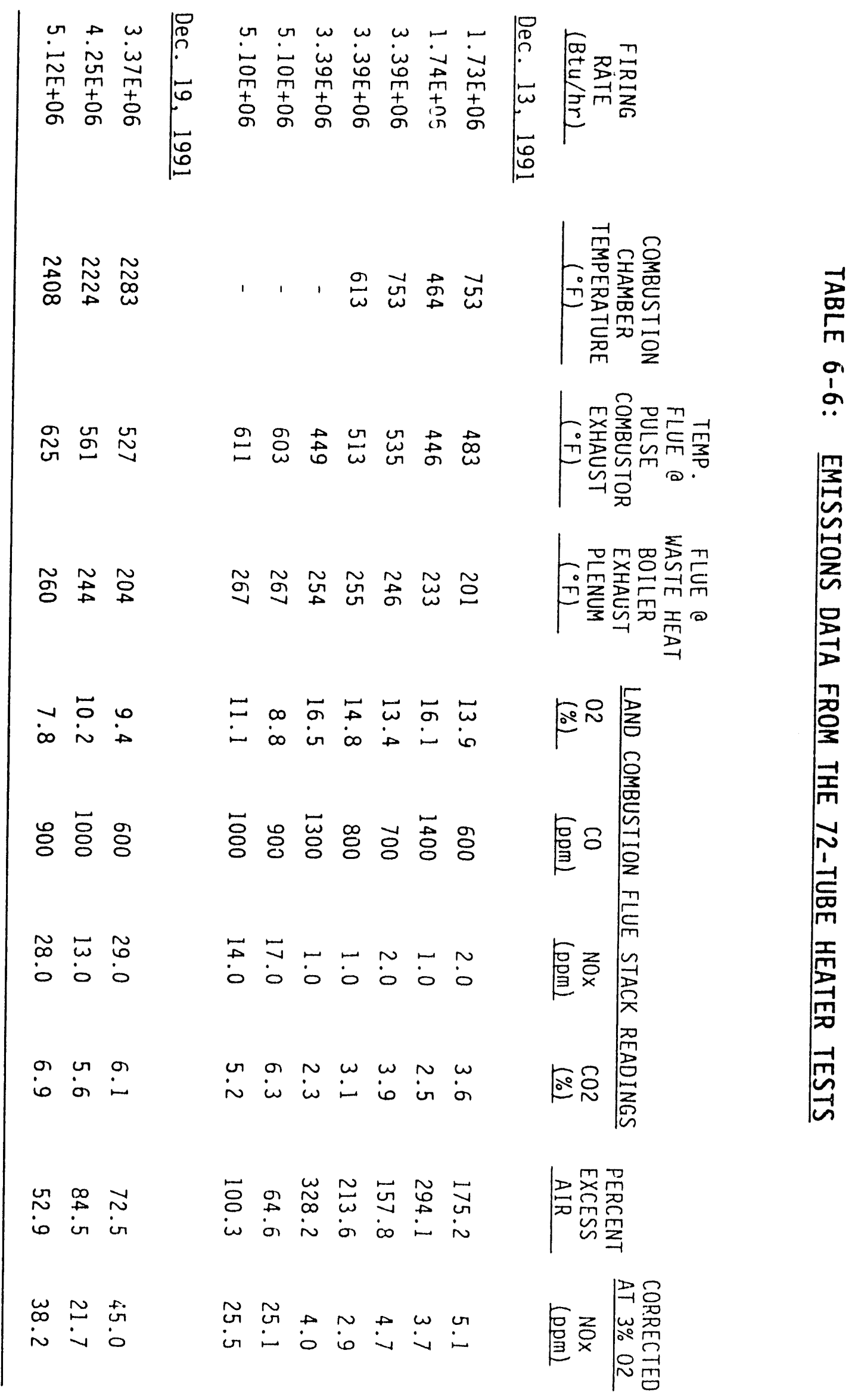




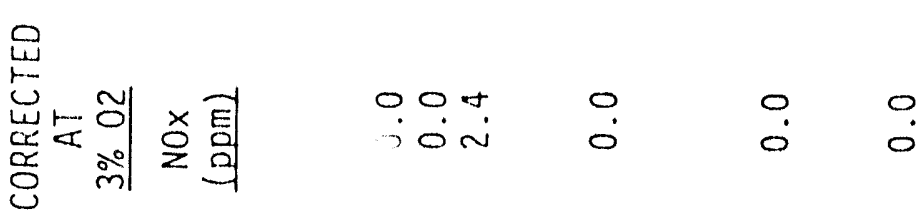

$\stackrel{\sim}{\sim}$

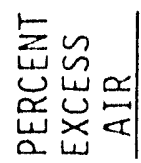

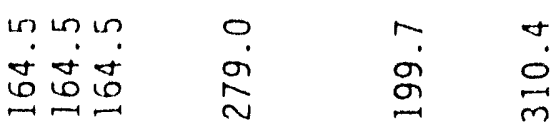

$-16$

ஸ்

ธิด

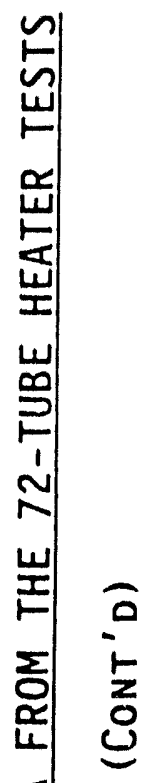

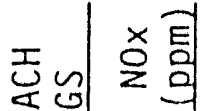

OON 0

00

$\underline{-1}$

衰司

它这

忈峲

8 켬

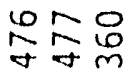

$\underset{\Xi}{\approx}$

怘

㸃祖

잉

志岁

$\approx$ बे

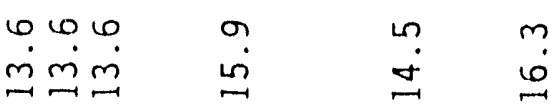

bo

$\infty$

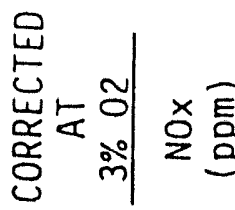

站出

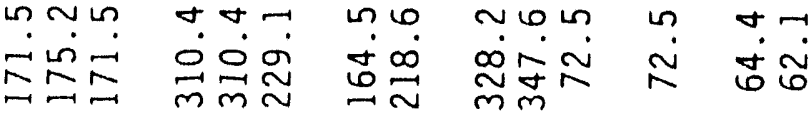

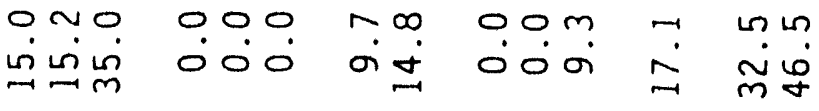

n్n

$\ddot{b}$
$\dot{1}$
$w$
$\ddot{w}$

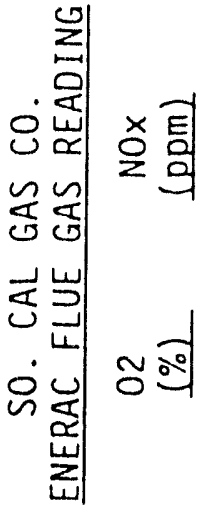

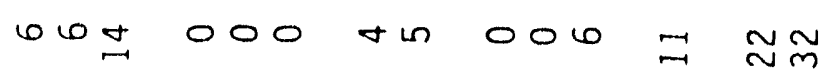

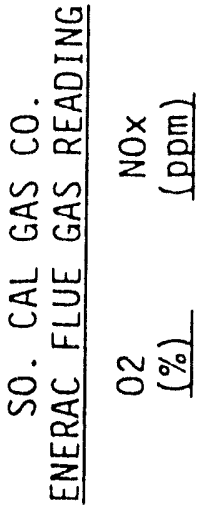

$\infty \sigma \infty$

$m m-$

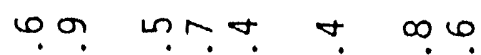
$m \dot{m}$ ம்

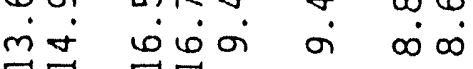

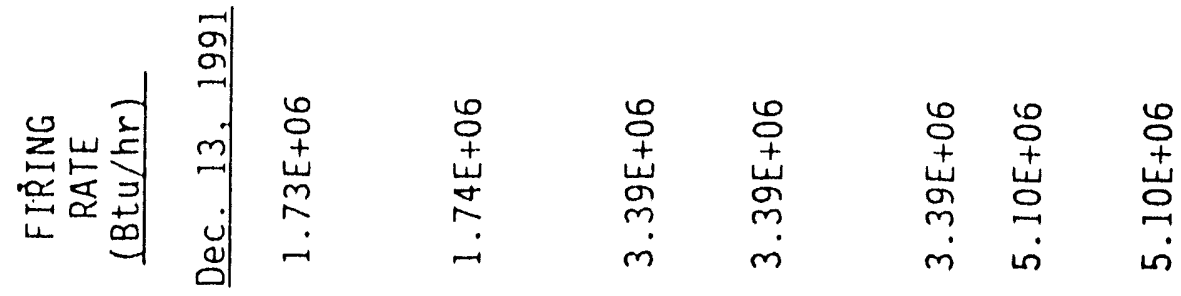


150 psig) was also procured to cool the flue gas to about $400^{\circ} \mathrm{F}$ before it enters the muffler. This serves two purposes: A cooler flue gas would allow the use of less expensive carbon steel for fabrication, and the cooling also results in loss of acoustic energy of the flue gas and thus help to attenuate the noise level.

A test was run on December 4, 1991 to test the performance of the boiler and the muffler. The test data and results are summarized in Table 6-3. As can be seen, the acoustic noise level did attenuate by use of the muffler. Figure 6-8 shows a comparison of the noise levels for almost equivalent firing rate and excess air conditions. It was also observed that the noise level increases with increasing firing rate and/or excess air. Figure 6-9 shows the variation of acoustic noise level as a function of firing rate and excess air.

Another test was run on December 5, 1991 to study the performance of a new aerovalve 3.25 inches in diameter (as against the previous one, 3.68 " in diameter). Table 6-4 summarizes the test data and results. Table 6-5 compares the acoustic noise levels for comparable conditions (FR and excess air) and is plotted in Figure 6-10. It is evident that the smaller diameter (3.25") aerovalve performed worse with respect to noise levels.

The tests also showed a very high acoustic noise level at the inlet air plenum side. An air plenum muffler was designed for the same and tested on December 19, 1991. Figure 6-11 shows the reduction in noise level at the air plenum.

\section{EMISSIONS FROM THE PULSE HEATERS}

In order to verify the low emissions characteristic of the MTCI pulse combustion heater, measurements were made for emissions of $\mathrm{NO}_{x}, \mathrm{CO}, \mathrm{SO}_{2}$ and combustibles at the flue gas exhaust plenum by specialized analyzers. Three different analyzers were used. MTCI used a Land Combustion $\mathrm{NO}_{x}$ Analyzer; an Enerac Analyzer was provided by Southern California Gas Company (SCGas); and a Bacharach Analyzer was brought to MTCI's Santa Fe Springs laboratory by California Polytechnic Institute's (CalPoly, Pomona) students. The test was 


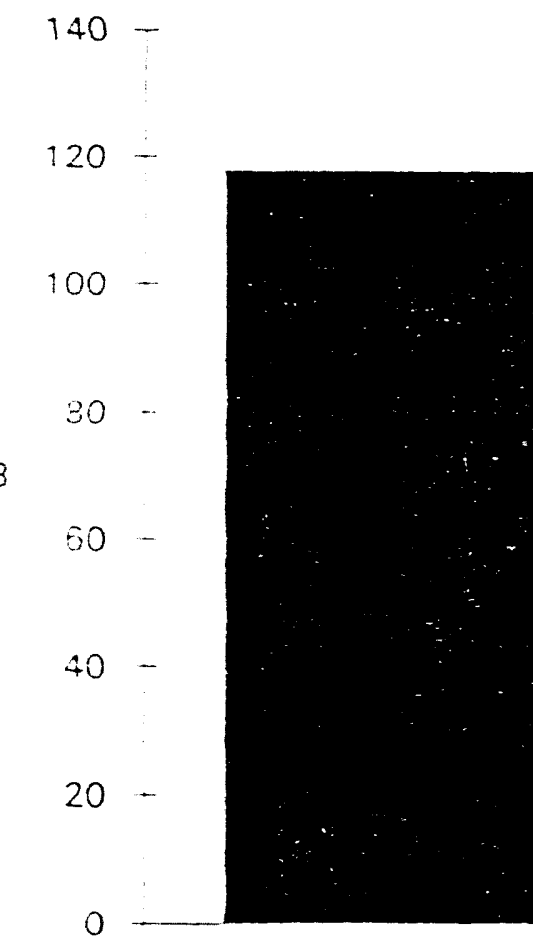

FR : 3.7 MMBtu/hr

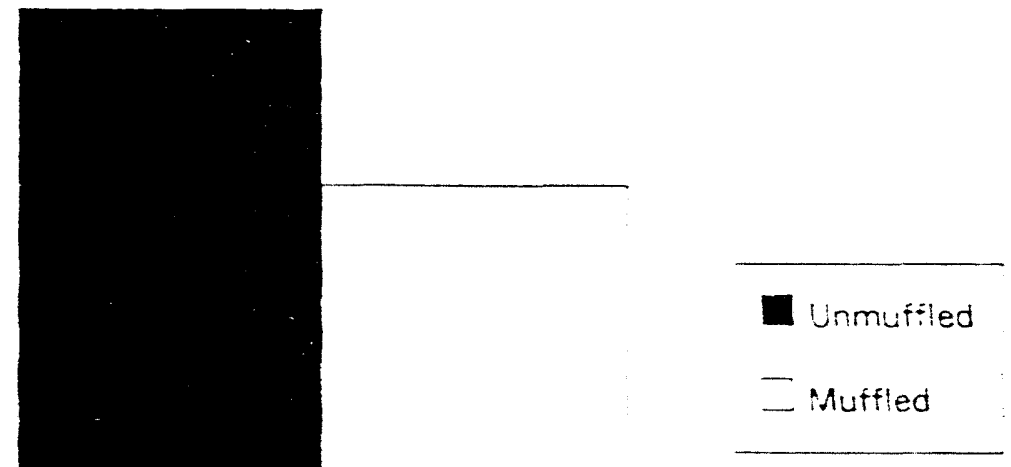

FR : $5.6 \mathrm{MMBtu} / \mathrm{hr}$

FIGURE 6-8: EFFECT OF BOILER AND STACK MUFFLER

ON ACOUSTIC NOISE LEVEL 


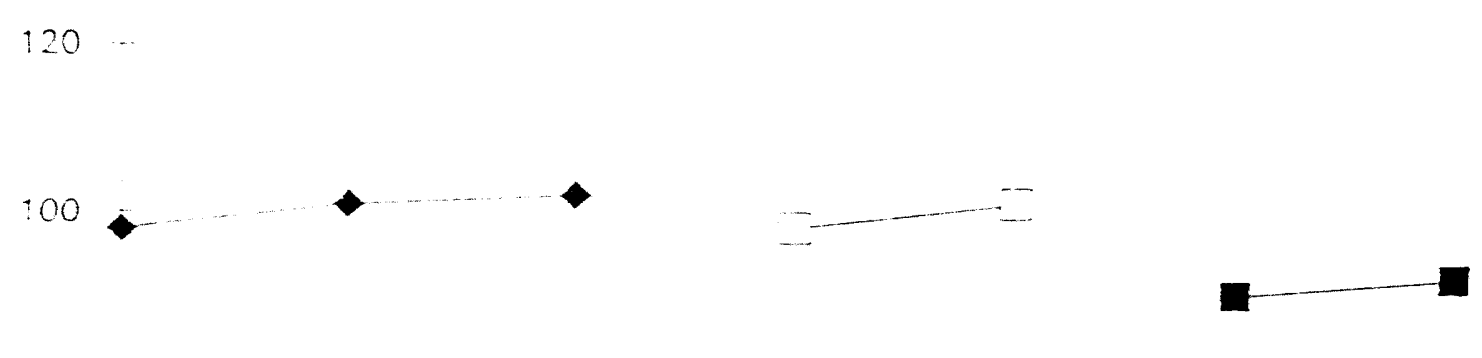

80

aFR : 3.7 MMEtuhr 


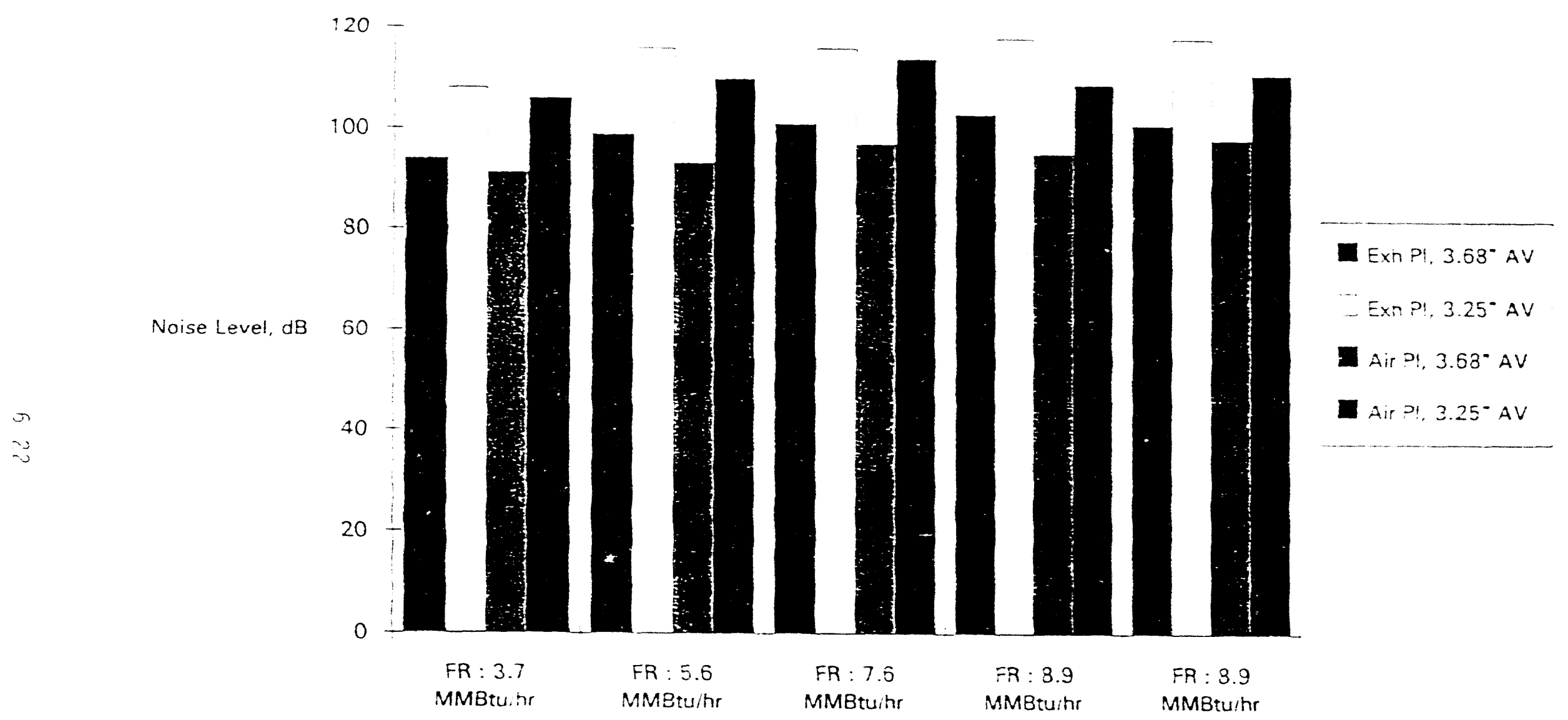

FIGURE 6-10: COMPARISON OF NOISE LEVELS FOR TWO TYPES OF AEROVALVES 


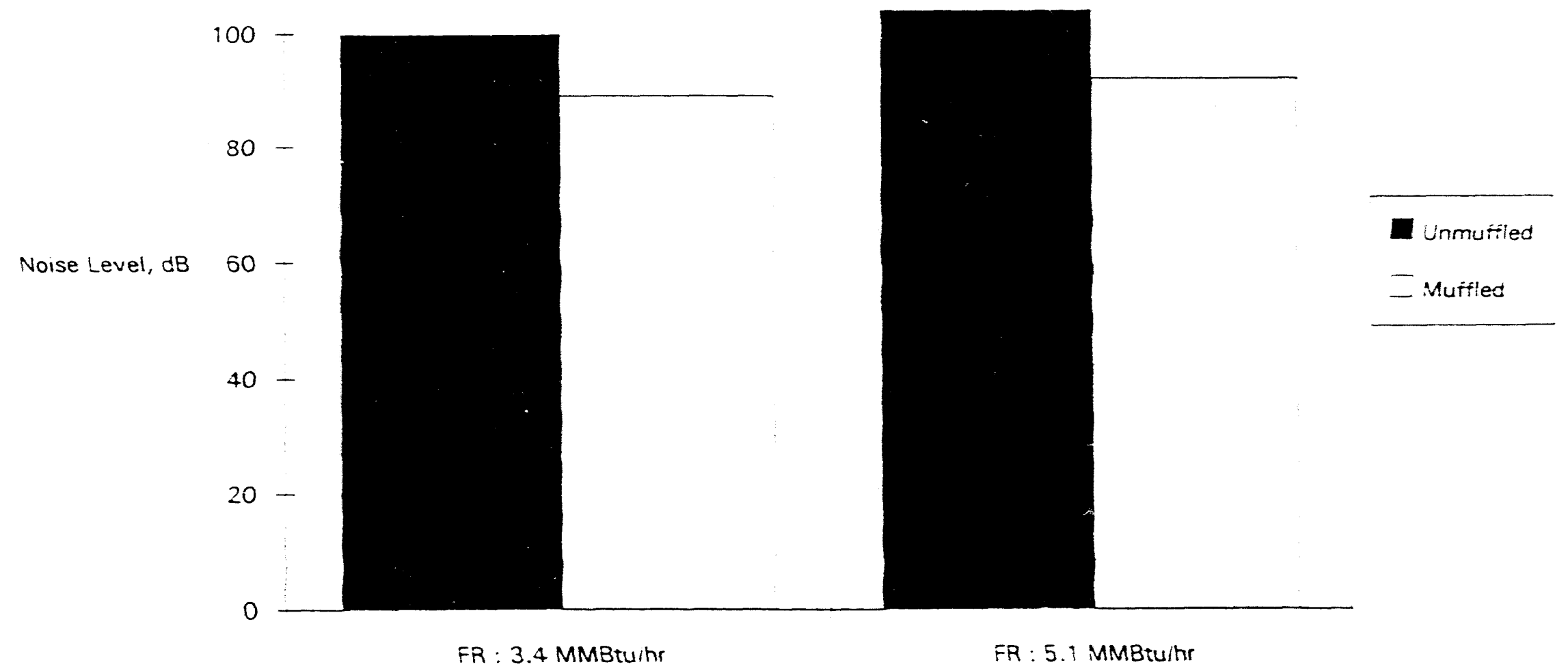

FIGURE 6-11: REDUCTION IN NOISE LEVEL BY AIR PLENUM MUFFLER 
also a part of CalPoly's project to test low NOx combustors. SCGas is the industrial liaison for Calpoly's project.

Table 6-6 shows the emission data obtained during the test conducted on December 13 and December 19, 1991. The December 13, test was conducted with all three $\mathrm{NO}_{x}$ analyzers. The December 19 test utilized only MTCI's Land Combustion Analyzer.

As evident from the table, NOx emissions from the pulse heater were quite 10w. The maximum value of $\mathrm{NO}_{x}$ (converted to $3 \% \mathrm{O}_{2}$ ) was observed to be $45 \mathrm{ppm}$, much lower than the currently avallable combustion technologies. The relatively low value of $\mathrm{NO}_{x}$ at low firing rates on December 13 may be attributed to the fact that the air was too much in excess resulting in incomplete combustion. This is also supported by the low combustion chamber temperature observed. Howeve:", at higher firing rate ( $5.10 \mathrm{MMBtu} / \mathrm{hr}$ ), air was reasonable and the $\mathrm{NO}_{x}$ values measured were more realistic. Whereas the three analyzers showed marked differences in the value of $\mathrm{NO}_{x}$ at low firing rates, the data obtained at high firing rates were very much in agreement. This may also be attributed to the fact that all these instruments have an accuracy of about \pm 5 to $10 \mathrm{ppm}$ and, hence, may not accurately detect low NO $0_{x}$ emissions. 


\section{SECTION 7.0 \\ PERFORMANCE EVALUATION TEST OF A \\ 72-TUBE PULSE HEATER UNDER \\ BLACK LIQUOR SIMULATED CONDITIONS}

The prototype 61-tube heater module and its performance were previously evaluated only at the laboratory-scale and during this period. It soon became apparent that it was essential that at least one heater module be tested using real black liquor feed at conditions similar to those that would be required at New Bern. This would require numerous other components such as venturi and caustic scrubbers, an impact separator with heat exchanger, a cyclone, a flare, waste heat boilers, mufflers, etc. A cost. and performance analysis indicated that a paper mill sludge could be used as a feed material to simulate black liquor without incurring the additional cost for the conversion of the process chemicals to green liquor. The MTCI process was also designed to process a wide spectrum of energy-bearing waste and biomass in an environmentally and economically sound manner.

Three paper mills showed an interest in hosting the heater performance evaluation tests using their sludge waste. Of the three, namely, Smurfit Newsprint Corporation, Inland Container Curporation (ICC), and Simpson Paper Company, ICC was chosen to be the host site. A 1 -ton per hour heater evaluation pilot unit was to be installed at $16 C^{\prime}$ s recycle paper mill site in Ontario, California. One 72 -tube heater bundle was to be used to gasify 1 -ton per hour of wet sludge with a moisture content ranging from 50 to 80 percent.

Inland Container Corporation recycles currugated boxes and currently has a non-hazardous sludge waste product consisting of cellulose paper fibers that are too small to be used in making newsprint. The mill disposes of 50 tons per day of this fibrous sludge waste in a nearby landfill at considerable expense to the mill. The pilot would establish the industrial scale operability of the MTCI pulse heater in a paper mill environment. The Cal ifornia Energy Commission provided financial support (cost sharing) of $\$ 500 \mathrm{~K}$ for the pilot 
and tests and ICC provided a site and utilities as well as feed and other ancillary participation.

The pilot gasifier was designed to process approximately 20 tons per day of wet sludge with moisture contents ranging from 50 to 80 percent. [able 7-1 shows the chemical analysis of a typical sludge waste from the host paper mill. The sludge consists of cellulose fiber but does not contain any inks or dyes. The chemical analysis detected only two metals: arsenic and lead. After acquiring the required permits and insurance, the installation of the pllot unit for the heater assembly at Inland container corporation was initiated and completed in four months.

\subsection{PROCESS DESCRIPTION}

Eigure $7-1$ shows the process flow diagram of the pilot facility for the sludge simulation of black liquor. The process consists of a fluid-bed gasifier (R-1) heated by a pulse combustion heater module $(H-1)$ inserted into the flutd-bed gasifier. As previously described, the tube bundle heats the flutd bed indirectly as in a fire-tube boiler. The fluid bed is comprised of either limestone or sand (in actuality, both were used during the test phase) and is fluidized with either steam or recycle product gas or a mixture of the two. In the initial stage, only steam fluidization would be done, though provisions has already been made for recycle yas fluidization. A second blower (B-2) is provided to fluidize the bed with air during start-up.

\subsubsection{IHE GASIFICATION PROCESS}

Sludge is fed to the reactor via a feeder system $(x-1, x-2)$, described later. It is gasified in the fluid bed and the hot particulate-laden product gas exits the reactor at about $1300^{\circ} \mathrm{F}$. The product gas first passes through an impact separator-cum-superheater (E-1) where it not only loses a major fraction of the particulates which are fed back to the reactor, but also heats up the fluidizing gas. The cooler product gas then passes through a waterjacketed cyclone $(V-1)$ where most of the solids are removed and collected in a drum $(V-2)$. The product gas exits the cyclone at about $900^{\circ} \mathrm{F}$ and enters the venturi scrubber $(x-3)$. The latent heat and the particulates from the gas are removed by a jet venturi scrubber $(X-3)$ and a scrubber vessel $(V-3)$. The 
TABLE 7-1:

\section{CHEMICAL ANALYSIS OF TYPICAL SLUDGE WASTE \\ (FROM HOST PAPER MILL)}

\begin{tabular}{|c|c|c|}
\hline ULIIMATE & $\begin{array}{l}\text { NEWSPRINT } \\
\text { SLUDGE WI.\% }\end{array}$ & $\begin{array}{l}\text { CORRUGATED } \\
\text { CARDBOARD } \\
\text { SLUDGE WI \% }\end{array}$ \\
\hline $\begin{array}{l}\mathrm{C} \\
\mathrm{H} \\
\mathrm{N} \\
\mathrm{S} \\
0 \\
\mathrm{CL} \text { (by difference) }\end{array}$ & $\begin{array}{r}42.12 \\
5.65 \\
0.30 \\
1.41 \\
34.00 \\
0.02\end{array}$ & $\begin{array}{r}48.60 \\
6.37 \\
0.37 \\
0.30 \\
41.56 \\
0.00\end{array}$ \\
\hline & Btw/1b & $B t w / 1 b$ \\
\hline $\begin{array}{l}\text { HHV (dry) } \\
\text { HHV (wet) }\end{array}$ & $\begin{array}{l}7,604 \\
5,239\end{array}$ & 8,863 \\
\hline PROXIMAIE & $W 1 \%$ & WI.\% \\
\hline $\begin{array}{l}\text { VM } \\
\text { Ash } \\
\text { Moisture } \\
\text { Fixed Carbon } \\
\text { (by difference) }\end{array}$ & $\begin{array}{l}34.73 \\
16.50 \\
47.03 \\
1.74\end{array}$ & $\begin{array}{c}45.70^{\star} \\
2.80 \\
49.50 \\
2.00 \star\end{array}$ \\
\hline TOTAL METAIS & mg. $\mathrm{kg}$ & \\
\hline $\begin{array}{l}\text { Arsenic } \\
\text { Lead } \\
\text { All Others }\end{array}$ & $\begin{array}{l}0.41 \\
0.57 \\
\text { Not Detected }\end{array}$ & \\
\hline $\begin{array}{l}\text { SEMI - VOLATILE AND } \\
\text { VOLATILE ORGANICS }\end{array}$ & $m g / k g$ & \\
\hline $\begin{array}{l}\text { Xylenes } \\
\text { All Others }\end{array}$ & $\begin{array}{l}5.12 \\
\text { Not Detected }\end{array}$ & \\
\hline
\end{tabular}




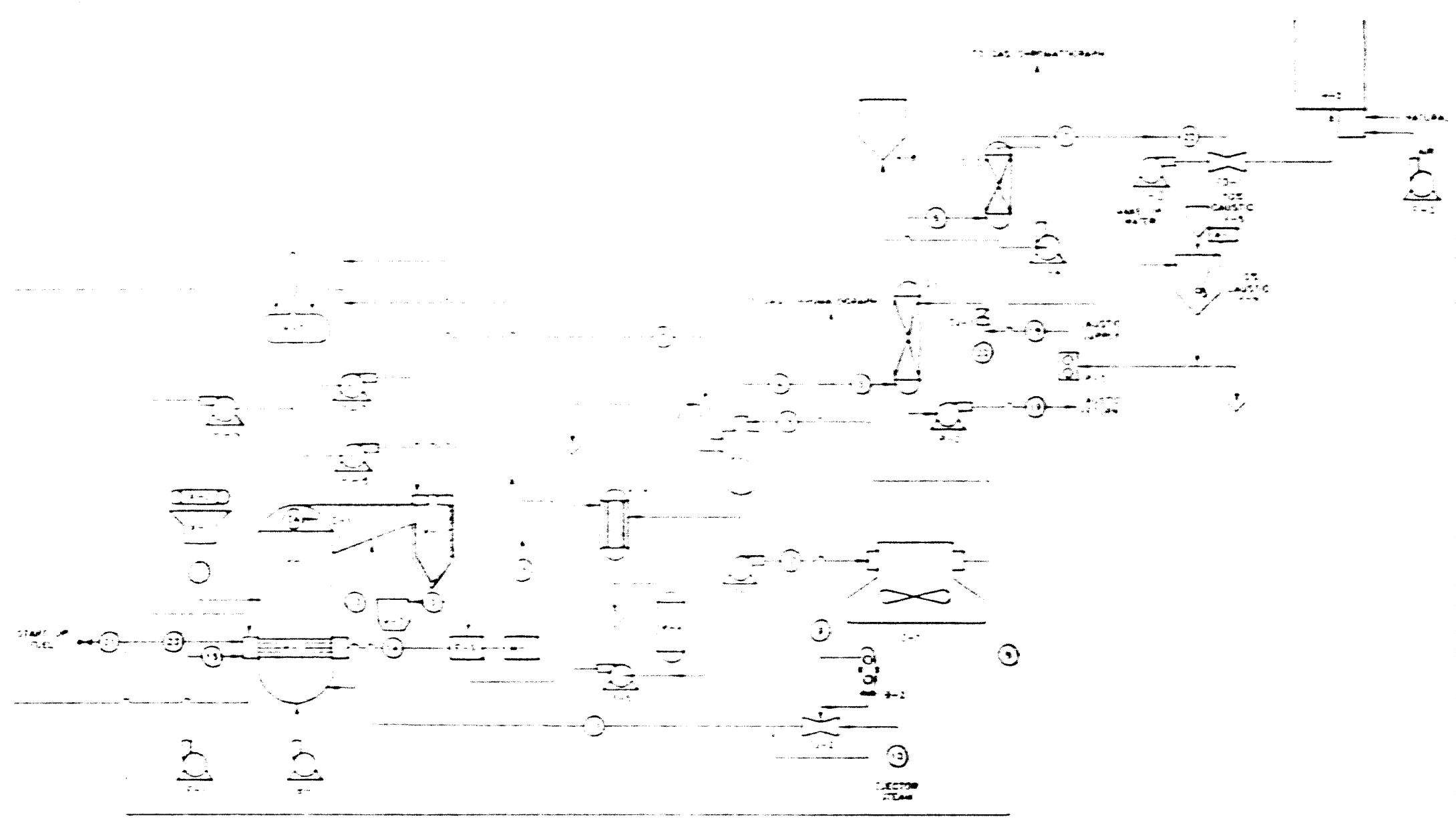

FIGURE 7-1: PROCESS FLOW DIAGRAM FOR THE SLUDGE GASIFICATION PILOT PLANT 
product gas exits the scrubber tank at $120 \cdot 150^{\circ} \mathrm{F}$. The gas then scrubber off hydrogen sulfide with a 10 percent caustic soda in a packed bed column $(C-1)$. The product gas leaving the scrubber $(C-1)$ is nearly moisture - and sulfurfree. A second polishing column $(C-2)$ uses circulating water to further remove any solids particles. The product gas leaving the column (C-2) is used for firing the pulse combustor (H-1) and fluidizing the reactor. The remaining export fuel gas is flared in $\mathrm{H}-2$.

\subsubsection{PULSE COMBUSTION HEATER SYSTEM}

The heat required for the gasification is supplied indirectly by the pulse combustion heater $(H-1)$. The pulse combustor is fired with natural gas for start-up and recycled product fuel gas at steady state. Combustion air is introduced by a forced draft blower $(F-1)$. The hot flue gases from the heater at $1600^{\circ} \mathrm{F}$ are cooled to $400^{\circ} \mathrm{F}$ in a Waste Heat Recovery Steam Generator (WHRSG). The cooled fluid is passed through a two-stage, high efficiency muffier $(M-1)$ before emission into the atmosphere.

\subsubsection{Fluidizing Media CIRCUIT}

Plant steam at 15 psig from the facility is superheated in E-1 to $800^{\circ} \mathrm{F}$ for bed fluidization. At steady state condition, a fraction of process gas (split stream after venturi scrubber) is recycled via a sleam ejector to superheater ([-]). The superheated steall and recycle process gas mixture is used to fluidize the bed. By doing so, the steall usage is reduced, reducing the heat load in the venturi scrubber circuit.

\subsubsection{VENTURI SCRUBBER SYSTEM}

The hot gases emerging from the cyclone are cooled and scrubbed of the solid particulate via a water spray jet at the venturi scrubter. Also, most of the steam in the gas condenses out. The condensate and scrubbing water are pumped to an air-cooled fin fan heat exchanger (E-2) before being recycled back to the venturi scrubber. Part of the venturi scrubber water is pumped to a filter canister to knock off any remaining particulates before recycling back to the scrubber. The steam condensed in the venturi scrubber circuit is reinjected from the filter canister. 


\subsubsection{Caustic-Scrubber Circuit}

The hydrogen sulfide in the product gas steam is reduced by caustic soda scrubbing in the absorption tower $(C-1)$. Caustic soda available from the plant at 50 percent concentration is diluted to 10 percent concentration before being pumped to the absorption tower. The liquid level in the tower is maintained by continuous recirculation of caustic effluent. Excess effluent is discharged to a discharge tank.

\subsubsection{COOLING WATER CYCLE}

Cooling water is utilized to remove heat from the following process equipment:

- Pulse Combustor Chamber

- Cyclone (V-1)

- Ducts connecting the cyclone to the impact separator/reactor and the venturi scrubber

- WHRSG

Water is supplied to the above equipment from flash tank (V-7). The heater water/steam mixture exiting the equipment returns to the flash tank for evaporative cooling. The water flow is controlled via natural circulation due to density different between inlet and outlet streams. The height of the flash tank was calculated to be $35 \mathrm{ft}$. above the base in order to achieve natural circulation.

The steam produced in WHRSG and the flash tank are passed to the flare. In a commercial facility this can be used as process steam or export steam.

\subsection{POSSIBLE POINT SOURCES OF EMISSIONS}

- Char/ash discharge

- Flue gases

- Flared export product gas 
The char/ash discharges from the second cyclone into a local hopper and does not emit any dust. The flue gas emissions consist of $\mathrm{NO}_{x}, \mathrm{SO}_{2}, \mathrm{O}_{2}, \mathrm{~N}_{2}$, $\mathrm{CO}_{2}$, and $\mathrm{H}_{2} \mathrm{O}$. Emissions of $\mathrm{NO}_{x}$ are expected to be about $25 \mathrm{ppm}$ at 3 percent $\mathrm{O}_{2}$ when the pulsed combustor is fired with natural gas and lower when fired with the hydrogen-rich product gas. $\mathrm{SO}_{2}$ emissions of $9 \mathrm{ppm}$ are anticipated when firing the pulse combustor on product gas. The product gas fuel after passing through the $\mathrm{H}_{2} \mathrm{~S}$ caustic scrubber contains $50 \mathrm{ppm}$ of $\mathrm{S}$ as $\mathrm{H}_{2} \mathrm{~S}$. The flared export gas produces emissions of a lower $\mathrm{NO}_{x}$ level due to the hydrogen content of the gas. The flare and flue gas emissions are maximum during start-up (3-6 hrs) when only natural gas is used to fire the pulse combustor. Also, at start-up, all of the product gas is flared and steam only is used to fluidize the reactor bed.

\subsection{PROCESS EQUIPMENT DESCRIPTION}

A list of the major equipment utilized in the gasification system is shown in the process flow diagram (Figure 7-1) and appears in Table 7-2.

A description of the major component systems follows.

\subsubsection{The SLUdGe Feeder System (X-1 and $X-2)$}

A schematic diagram of the sludge feeding system is shown in Figure 7-2. It consists of a ground feeder, a first-stage belt conveyor, a second-stage belt conveyor, a metering bin, a 20 -inch knife valve, a rotary valve, and finally, a feed screw. The ground level feeder feeds sludge material to the first stage conveyor (at a steeper angle than the first belt). The secondstage belt delivers the sludge to a twin-feed feeder. Sludge travels through the 20 -inch knife valve (open during operations) and rotary valve into the injection screw. The injection screw feeds the sludge to the gasifier. A bindicator located at the metering bin controls the feeding rate of the ground feeder. Both conveyor belts operate at all time at constant speed. The feed rate to the gasifier is controlled via a speed controller on the twin-feed feeder. 
TABLE 7-2:

LIST OF MAJOR EQUIPMENT

A-1 Agitator

B-1 Fluidizing Blower

B-2 Blower (Recycle Gas)

C- $1 \quad \mathrm{H}_{2} \mathrm{~S}$ Scrubber

C-2 Demister

E-1 Superheater

E-2 Air Cooler

E-3 Boiler

ED-1 Product Gas Eductor (flare)

EJ-1 Scrubber Ejector

EJ-2 Steam Ejector

$\mathrm{F}-1$ Combustion Air Fan

$\mathrm{F}-2$ Flare Combustion Air Fan

$\mathrm{F}-3$ Flare Pilot Fan

$\mathrm{H}-1$ Pulse Heater

$\mathrm{H}-2$ Flare

M-1 Muffler

P-1 Venturi Scrubber Pump

$\mathrm{P}-2 \quad \mathrm{H}_{2} \mathrm{~S}$ Scrubber Recycle Pump
P-3 Caustic Metering Pump

P-4 Demister Recycle Pump

P-5 Filter Pump

P-6 Pulse Combustor Cooling Pump

P-7 Cyclone Cooling Pump

P-8 Exhaust Stack Cooling Pump

R-1 Reactor

V-1 Recovery Cyclone

$V-2$ Cyclone Fines Bin

$V-3$ Scrubber Tank

$V-4$ Filter Blowdown Tank

$V-5$ Caustic Supply $50 \%$

V-6 Caustic Diluter $10 \%$

$V-7 \quad$ Flash Tank

V-8 Demister Caustic Catch

$V-9 \quad$ Filter

$X-1 \quad$ Sludge Feeder System

$X-2$ Belt Conveyor

$X-3$ Venturi Scrubber

The feeder is designed for a capacity of 1.5 tph of sludge.

\subsubsection{THE GASIFIER/REACTOR (R-1)}

The reactor as shown in Figure 7-3 consists of a refractory-1ined shel1 with sparge pipe distribution of air and steam in the bottom. A tube bundle is inserted into the bed and coupled to a pulsed combustion burner for heating the reactor. The process operates in a reducing environment except during start-up when the bed is fluidized with air until the bed temperature is above the dew point of steam. At this point, steam is used to complete the start-up heating and the system air is purged. Sludge feed to the reactor is started when the reactor reaches $1300^{\circ} \mathrm{F}$. The reactor produces a hydrogen-rich gas laden with char/ash particulates. The bulk of the solids return to the reactor from the impact separator and reacts further. The gasifier dimensions are approximately $10 \times 3 \times 10 \mathrm{ft}^{3}$. The gasifier is designed to operate at $15 \mathrm{psig}$ and $1100-1500^{\circ} \mathrm{F}$ and a throughput of approximately one ton per luur. 


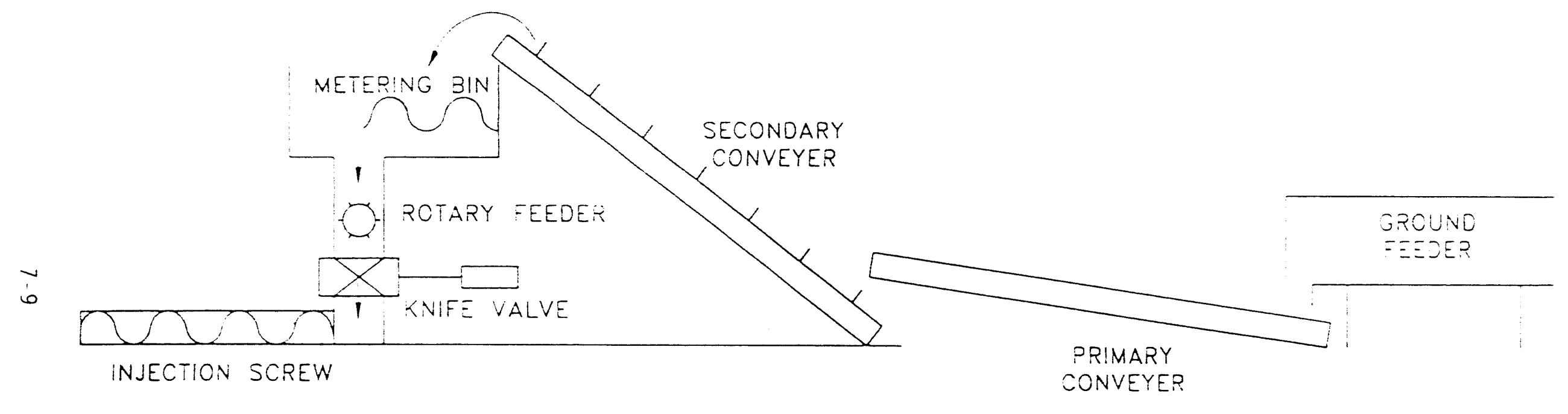

FIGURE 7-2: SLUDGE FEEDER SYSTEM 

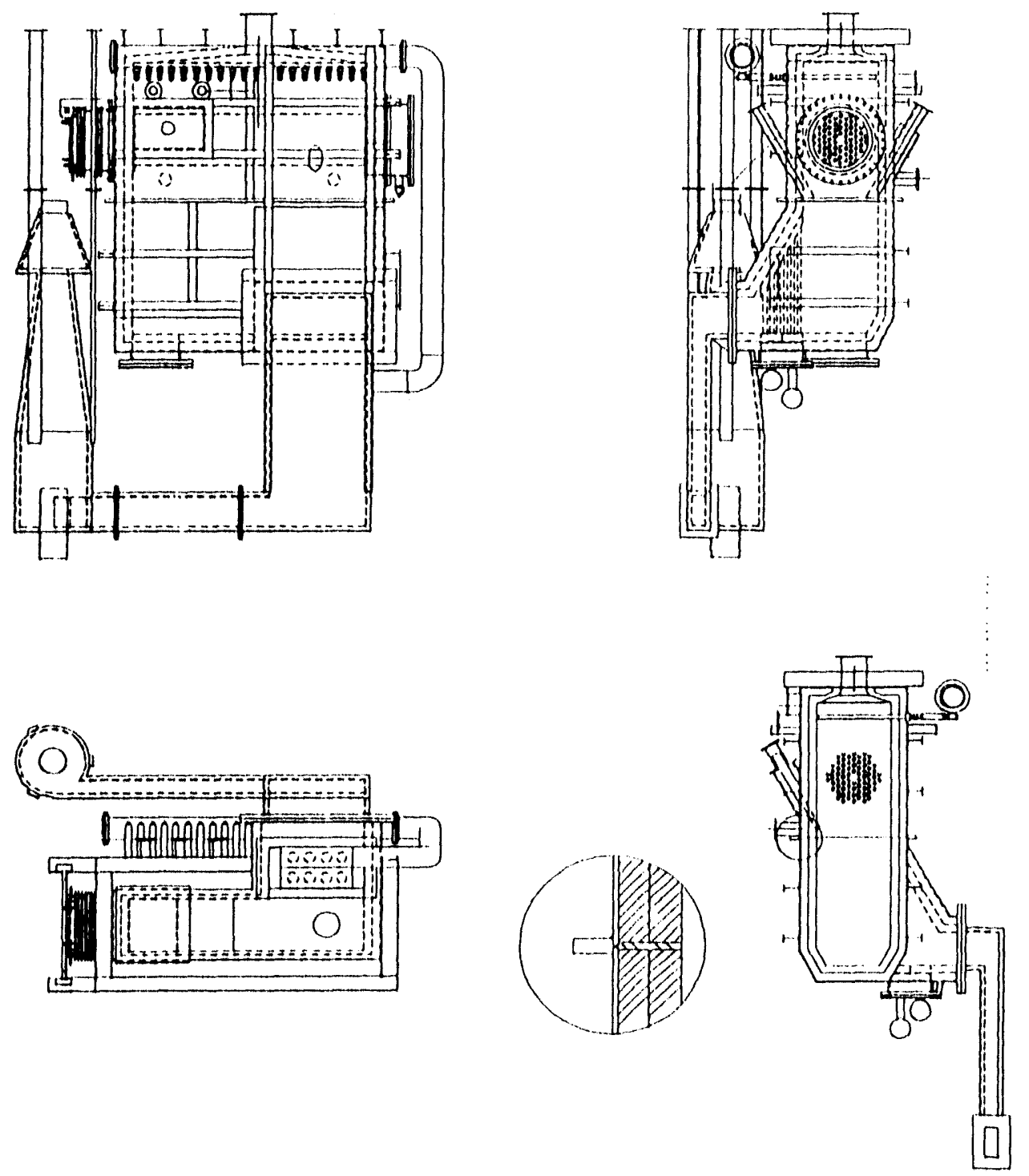


\subsubsection{PULSE COMBUStion HeAter}

Heat is supplied to the fluidized bed reactor by means of a pulsed combustion heater rated $7 \mathrm{million} B t \mathrm{H} / \mathrm{hr}$. A schematic diagram of the combustor heater tube bundle was shown in Figure 6-3. The pulsed combustor consists of a forced draft air plenum, refractory-lined and water-jacketed combustion chamber, aerovalves, fuel manifold, interlocked combustion control, pulse resonating 72 -tube bundle and exhaust plenum.

The basic components of the pulsed combustor are the aerovalves, the combustion chamber and the tailpipe. The aerovalves act as fluidic diodes and self-aspirate the required air volume into the combustion chamber from the air plenum with a frequency of $50-60 \mathrm{~Hz}$. Fuel gas is supplied to the test unit through a manifold under continuous pressure. Air is supplied via selfaspirating aerovalves from an air plenum. The partially combusted flue gas enters the pulse tube where combustion continues for a fraction of the total tube length. The flue gases then emerge into the exhaust plenum. The pulse combustor is designed to fire with any type of liquid gaseous fuels up to 7.0 MMBtu/hr.

\section{IGNITOR 'SYSTEM}

The combustor is equipped with a spark plug electronic ignitor set to light a pilot flame and the combustor all controlled by an interlocked control panel. The control panel uses a Fire Eye UV sensor to detect the presence of the pilot flame. Solenoid valves control the start-up of pilot and main gas flow to the pulsed combustor. Although the pilot will operate continuousiy for safety, once the pulse combustor is started up, the ignitor is not required for operation.

\subsubsection{IMPACT SEPARATOR AND CYCLONE: SOLID SEPARATIONS SYSTEMS}

Most of the particulates are removed from the product gas in the impact separator-cyclone system portion of the system. The impact separator is actually an integral part of the gasifier (Figure 7-3). It also acts as a superheater. The hot product gases pass through the spacing in between the tubes through which the fluidizirig steam or recycle gas is passed. A fraction 
of the solids separate out from the gas and return to the fluid bed for further reaction or to be taken out as bed overflow. The gases get cooled by indirect heat exchange with the fluidizing steam between entering the cyclone. Most of the solids is removed in the cyclone by centrifugal action. The cyclone is water jacketed in order to further cool the gas and the particulates. The particulates are collected in a drum, whereas the gases leave the cyclone for entry into the venturi scrubber.

The impact separator is designed for a product gas flow rate of $1000 \mathrm{scfm}$ and a heat removal rate of $900 \mathrm{KBtu} / \mathrm{hr}$. The cyclone can handle $1000 \mathrm{scfm}$ of process gas and $460 \mathrm{kBtu} / \mathrm{hr}$ of heat removal. The solid loading capacity of the cyclone is $200 \mathrm{lb} / \mathrm{hr}$.

\subsubsection{VENTURI SCRUBBER}

Figure 7-4 shows the schematic diagram of the venturi scrubber system. Hot product gas enters the venturi where it is cooled by a jet of water. Water vapor in the gas condenses out. The small amount of particles not removed in the cyclone is also scrubbed off. Adequate liquid separation is provided by a separator tank. The scrubbed product gas leaves the tank at 120-150\% with negligible moisture (equivalent to saturated water vapor at the partial pressure in the tank) and particulates. A demister screen at the exit of the scrubber tank (V-3) further removes any entrained droplets. The warm scrubbing water is pumped to a fan-finned cooler (E-2) where the water is cooled down by blowing air across the water tubes. The cooled water then circulates back to the venturi scrubber for the next cycle. The overflow from the venturi is passed through a filter ( $V-9)$ to remove any entrained particulates in the water.

\subsubsection{Caustic SCRubber System}

Most of the sulfur present in the sludge feed is converted to $\mathrm{H}_{2} \mathrm{~S}$ during the steam-reforming process. This $H_{2} S$ must be removed from the product gas before combustion in either the pulse cumbustor or the flare. The caustic scrubber system uses a 10 percent aqueous $\mathrm{NaOH}$ solution to absorb $\mathrm{H}_{2} \mathrm{~S}$ according to the reaction:

$$
\mathrm{NaOH}+\mathrm{H}_{2} \mathrm{~S}=\mathrm{Na}_{2} \mathrm{~S}+\mathrm{H}_{2} \mathrm{O}
$$




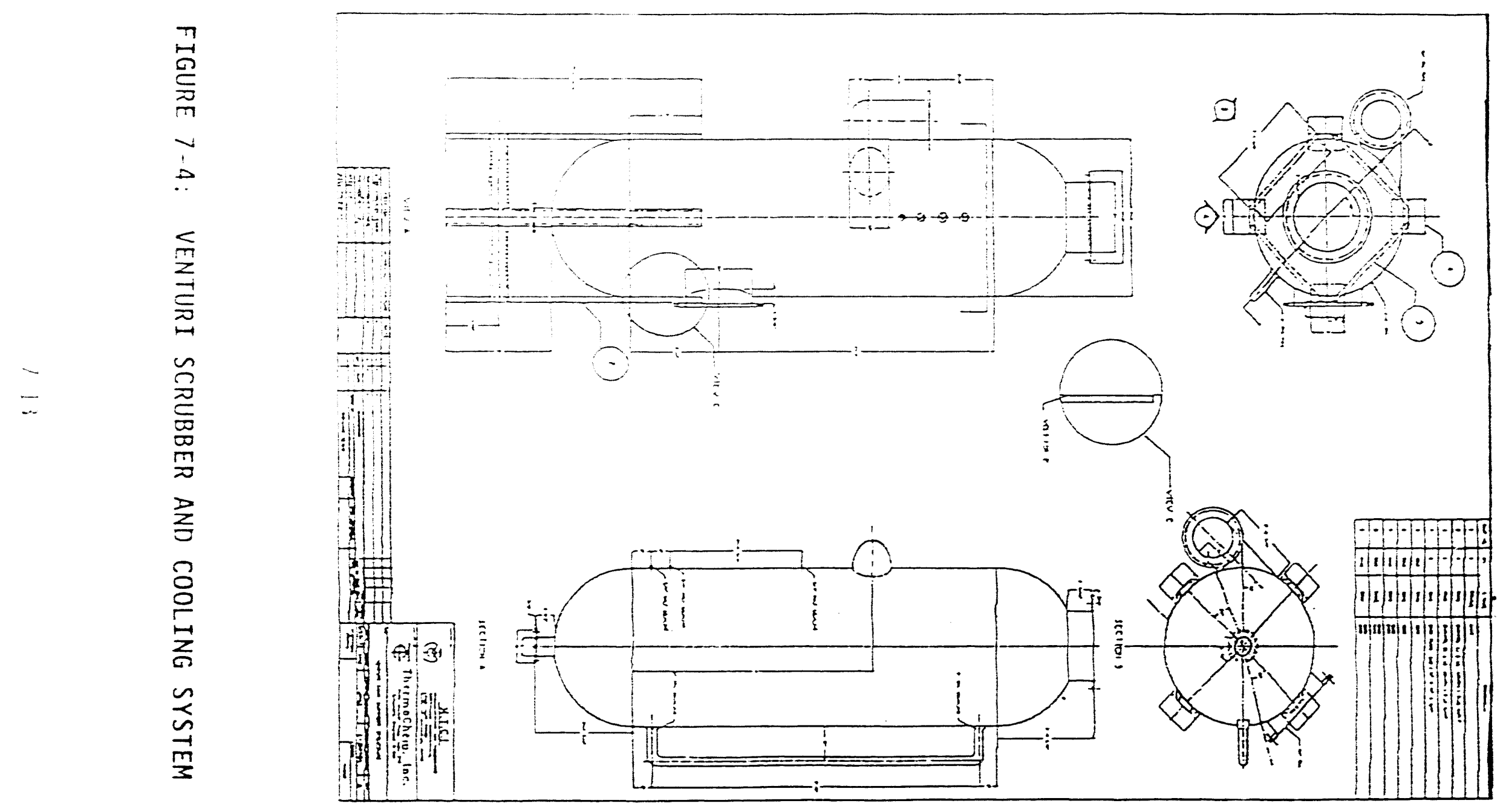


Figure 7-5 shows the schematic of the caustic scrubber column ( $C-1$, Figure 7-1). The column is 16 inches in diameter and 20 feet high and has two sections, each 10 feet long. It is packed with $1 \frac{1}{2}$-inch diameter 304 SS Koch brand flexirings to provide intimate gas liquid contact. The gases enter the column at the bottom and exit at the top. The aqueous $\mathrm{NaOH}$ enters at the top of the column and exits at the bottom. Another port provides makeup of $\mathrm{NaOH}$. A demister pad at the top of the column renuves any entrained droplets from the gas before it leaves the column. The scrubbing efficiency of the column is expected to be 99 percent. A pH value of 10 is maintained constantly for proper operation. The column is designed for a gas flow rate of $250 \mathrm{scfm}$ and caustic flow rate of $7 \mathrm{gpm}$. The operating temperature lies around $120-150^{\circ} \mathrm{F}$.

\subsubsection{Flue Gas WASTE Heat Recovery Steam Generator}

The Cleaver Brooks boiler that was used as the Waste Heat Recovery Steam Generator (WHRSG) at about $1500^{\circ} \mathrm{F}$ through a 12 -inch diameter inner tube at the one end and returns through 62 2.5-inch (OD) diameter tubes of 140-inch length to finally exit the boiler at about $400^{\circ} \mathrm{F}$. Water and steam mixture get heated on the shell side of the boiler. The boiler only acts as a heat removal system to cool down the flue gases to about $400^{\circ} \mathrm{F}$ so that less expensive carbon steel could be used for muffler fabrication, but also cuts down the acoustic energy of the flue gas, resulting in reduced noise level.

The Cleaver Brouks two pass boiler is rated at $4 \times 10^{\text {fi }} \mathrm{Btu} / \mathrm{hr}$ heat transfer rate at $150 \mathrm{psig}$ maximum. The maximum water flow allowed is $3450 \mathrm{lb} / \mathrm{hr}$ of steam at $150 \mathrm{psig}$. The boiler is designed for natural gas firing but is being used as a flue gas boiler. No fuel is fired inside the boiler.

\subsubsection{STACK MUFFLER}

Because of the strong pulsating flow in the combustion chamber and the pulse tube, the acoustic noise level of the heater system was observed to be tremendous. Even thuugh the introduction of the waste heat boiler reduced the acoustic energy of the flue gas quite a bit, further reduction was necessary 


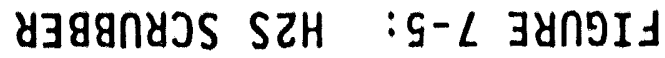
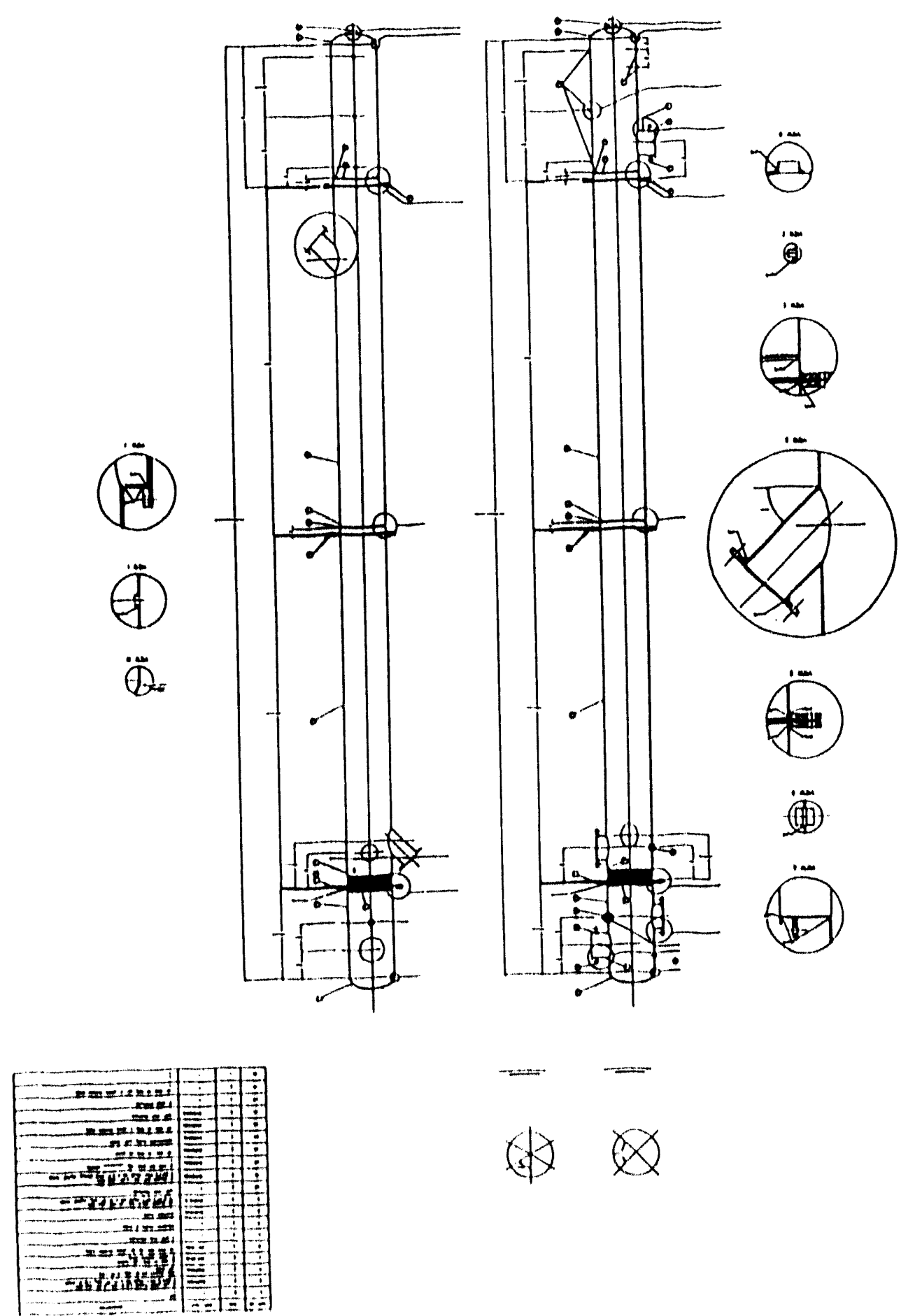

(1) 
to bring the noise level down to industrial specifications. The performance of this muffler was reported in a previous section.

Eigure 7-6 shows the schematic of the exhaust stack muffler. It consists of a two-stage baffled perforated muffling device. The first stage is 12 feet long and the second stage is 6 feet. Both stages consist of a 14-inch diameter inner pipe and 36-inch diameter outer pipe. The first stage consists of a 20 -inch long section with 3/8-inch perforation over 40 percent of the surface area. The second stage has a similar perforation but over 40-inch length.

The two stages are separated only across the shell between the tubes. The inner tube runs continuously into both the stages as evident from the figure. The muffler weighs approximately 3320 pounds.

The flue gases enter the muffler at about $500^{\circ} \mathrm{F}$ and exit at around $300^{\circ} \mathrm{F}$. The muffler was observed to attain a transmission loss of about 10-15 dB.

\subsubsection{AIR PLENUM MUfFleR}

Eigure 7-7 shows a schematic of the air plenum/muffler designed to reduce the acoustic emissions from the air inlet plenum. The design is similar to the stack muffler except for the length and diameter of inner and outer pipes and the perforations, as shown in the figure. The muffler was tested at the laboratory and was observed to attain a transmission loss of about $20 \mathrm{~dB}$. The results were reported in Section 6.5.

\subsubsection{DATA ACQUISITION AND CONTROL SYSTEM}

All the critical parameters required for process operations is continuously monitored from the control panel inside the control room, and also many of the critical parameters are measured locally such as pressure drop across the bed and natural gas flow rate to the pulse combustor. The list of all the parameters monitored and recorded from inside the control room and outside in the field is shown in Appendix A. 

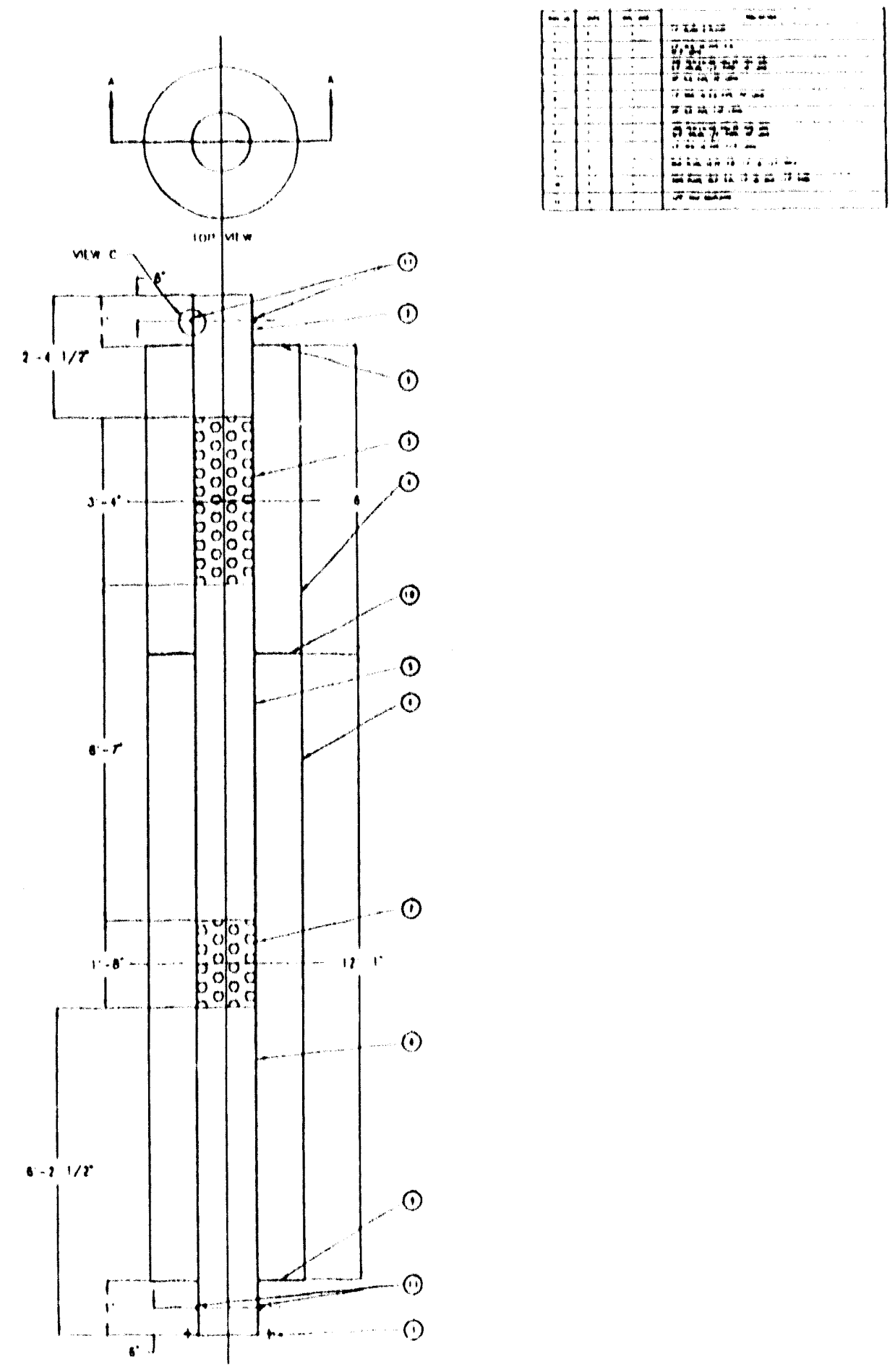

FIGURE 7-6: STACK MUFFLER AND EXHAUST 


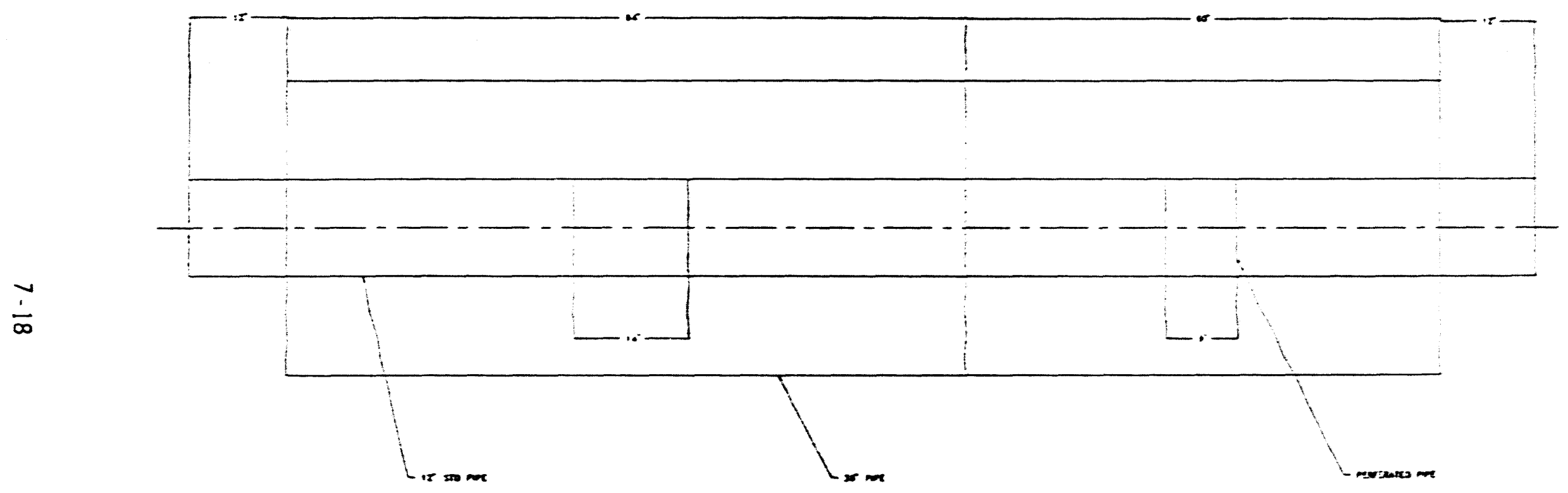

FIGURE 7-7: AIR PLENUM MUFFLER 
In addition to the above data acquisition which is recorded manually in the $\log$ sheet shown in Appendix $A$, there is an automatic data logger that was loaned to MTC1 by the Weyerhaeuser Paper Company, the data logger monitors and records all the remote temperatures and pressure measurements that are made inside the control room. The data logger sweeps every 5 minutes and data are saved on a disk in ASCII format.

\section{CONTROL PARAMETERS}

The critical control parameters are either controlled manually or automatically from the control panel in the control room. These are listed below:

- Fluidization velocity inside the reactor

- Pulse combustor firing rate

- Sludge feed rate to the gasifier

- Combustion air flow rate

- WHRSG back pressure limit

\section{GAS ANALYSIS EQUIPMENI}

The instruments used for gas analys is includes two MII M-200 gas chromatographs, one Tracor 540 gas chromatograph, one leledyne MAX-5 efficiency monitor, and two Horiba PIR-2000 yas analyzers.

The M 200 gas chromatoyraphs were used for detalled quantitative analyses of the gasifier product gases. Currentiy, they are configured to measure the concentrations of $\mathrm{H}_{2}, \mathrm{~N}_{2}, \mathrm{O}_{2}, \mathrm{CO}$, and $\mathrm{CO}_{2}$, methane, ethane, ethylene, propane, propylene, butane, iso-butane, $\mathrm{H}_{2} \mathrm{~S}$, and methyl mercaptan. The Model 540 gas chromatograph from Tracor was cutfitted with FID and FPD detectors for high sensitivity measurement of trace hydrocarbon and sulfur compounds.

To complement the data provided by the gas chromatograph, three continucus monitors were employed. The Teledyne MAX-5 efficiency monitor measures the concentrations of oxygen, carbon dioxide, carbon monoxide, and total combustible gases. It also calculates the combustion efficieicy. The Horiba PIR-2000 gas analyzers are used for continuous monitoring of a single 
specified gas component each. One of the units is configured to monitor nitric oxide (NO), another is configured to monitor sulfur dioxide $\left(\mathrm{SO}_{2}\right)$ only. The continuous analyzers were used primarily to monitor combustion products from the pulse combustor and incinerator units.

Two IBM-AT compatible computers were equipped for data collection and control of the GCS. The M-200 GC is controlled using EZ Chrom200 software from MTI. A Spectra Physics SP 4400 (ChromJet) was used to record chromatograms from the Tracor $540 \mathrm{GC}$. A Linseis L-6012 dual-channel chart recorder was also used for real-time recording of chromatograms on a hard copy for M-200.

\section{A. M-200 GAS CHROMATOGRAPHS}

Each M-200 has two channels that have separate chromatographic columns and detectors. By combining different types of column, carrier gas and operation conditions (temperature and column pressure) the range of detectable compounds can be optimized. Table 7-3 summarizes the configuration of two of the M-200s and the compounds they can detect.

TABLE 7-3:

CONFIGURATION SUMMARY OF TWO MCI M-200S

\begin{tabular}{|c|c|c|c|c|c|c|c|}
\hline \multicolumn{2}{|c|}{ GC CHANNEL } & $\begin{array}{l}\text { CARRIER } \\
\text { GAS }\end{array}$ & COLUMN & UE TECTOR & $\begin{array}{l}\text { TEMP. } \\
\left({ }^{\circ} \mathrm{C}\right)\end{array}$ & $\begin{array}{l}\text { PRESSURE } \\
\text { (PSi) }\end{array}$ & COMPOUNDS \\
\hline \multirow[t]{2}{*}{$\# 1$} & $A$ & Ar & $\begin{array}{l}\text { Molecular } \\
\text { Sieve } 5 \mathrm{~A}\end{array}$ & TC & 60 & 10.5 & $\mathrm{H}_{2}, \mathrm{O}_{2}, \mathrm{~N}_{2}, \mathrm{CH}_{4}, \mathrm{CO}$ \\
\hline & B & Ar & Hayesep A & $T C$ & 40 & 15.5 & $\mathrm{CH}_{4}, \mathrm{CO}_{2}$, ethylene, ethane \\
\hline \multirow[t]{2}{*}{$\# 2$} & A & $\mathrm{He}$ & $D B-5$ & TC & 35 & 16.5 & $\begin{array}{l}\text { propane, } \mathrm{SO}_{2} \text { and } \mathrm{H}_{2} \mathrm{O} \text { (CO- } \\
\text { elute) iso-butane, } \mathrm{n} \text {-butane, } \\
\text { methyl mercaptan and } \mathrm{HC} \\
\text { higher than } \mathrm{C}_{4}\end{array}$ \\
\hline & B & $\mathrm{He}$ & Hayesep $A$ & $1 C$ & $7 C$ & 18.0 & $\begin{array}{l}\mathrm{CO}_{2} \text {, ethylene, ethane, } \mathrm{H}_{\mathrm{S}}, \\
\mathrm{COS} \text {, propylene, } \mathrm{SO}_{2} \text {, and } \mathrm{H}_{2} \mathrm{O}\end{array}$ \\
\hline
\end{tabular}




\section{B. TRACOR 540 GAS CHROMATOGRAPH}

The Tracor $540 \mathrm{GC}$ is a general purpose gas chromatograph. It features microprocessor control of all temperatures with ten methods stored in protected memory, five level oven temperature programming, built-in diagnostics for error detection, RAM battery backup, etc. The column oven can be heated up to $400^{\circ} \mathrm{C}$. Linear program rate up to $40^{\circ} \mathrm{C} / \mathrm{min}$ can be used.

The Tracor 540 GC is equipped with a flame photometric detector (FPD). The detector is specific for detecting sulfur and/or phosphorous compounds. At the same time, the detector is able to provide a signal of flame ionization detection (FID), which responds to all hydrocarbons.

The column installed in the Tracor $540 \mathrm{GC}$ is a J\&W megabore $(30 \mathrm{~m} \times$ $0.545 \mathrm{~mm}$ ) fused silica capillary column. The stationary phase used in the column is GS-Q, a porous polymer stationary phase. This column is able to separate light hydrocarbons up to $C 8$ and common sulfur compounds seen in the fuel industry.

An air-actuated 6-port valve is installed in the GC for gas sampling. Both the action of the valve and the temperature of the valve oven are controlled electronically by the microprocessor program. A sample injection port is also installed for the purpose of calibration and occasional liquid sample analysis.

The detector signal is collected and integrated by a Spectra-Physics SP4400 integrator. The integrator analyzes the chromatogram and print the result and the chromatogram on the ink-jet printer. The collected data can be sent to a PC through a RS-232 serial cable.

\section{TELEDYNE MAX-5 EFFICIENCY MONITOR}

The MAX-5 efficiency monitor measures the oxygen, carbon monoxide and total combustible compounds directly. It calculates the carbon dioxide and combustion efficiency based on pre-programmed fuel properties. This instrument provides accurate measurement of oxygen and low concentration carbon monoxide $(<1000 \mathrm{ppm})$ in the test gas. 
D. LAND COMBUSTION GAS ANALYZER

The land combustor gas analyzer measures ', $\mathrm{CO}, \mathrm{CO}_{2}, \mathrm{NO}_{x}, \mathrm{SO}_{2}$, flue gas temperature, and draft. It calculates the carbun dioxide based on preprogrammed fuel properties.

\subsection{PLANT LAYOUT AND THE CURRENT STATUS OF THE PILOT PLANT}

Figure 7-8 shows a schematic drawing of the plant layout. Figure 7-9 shows a recent photograph of the facility. the plant has been completely commissioned. Currently it is being debugged for leaks, proper pipings and connections, etc. The plant is scheduled to undergo shakedown test within a few weeks. A 500-hour continuous test will follow thereafter. 


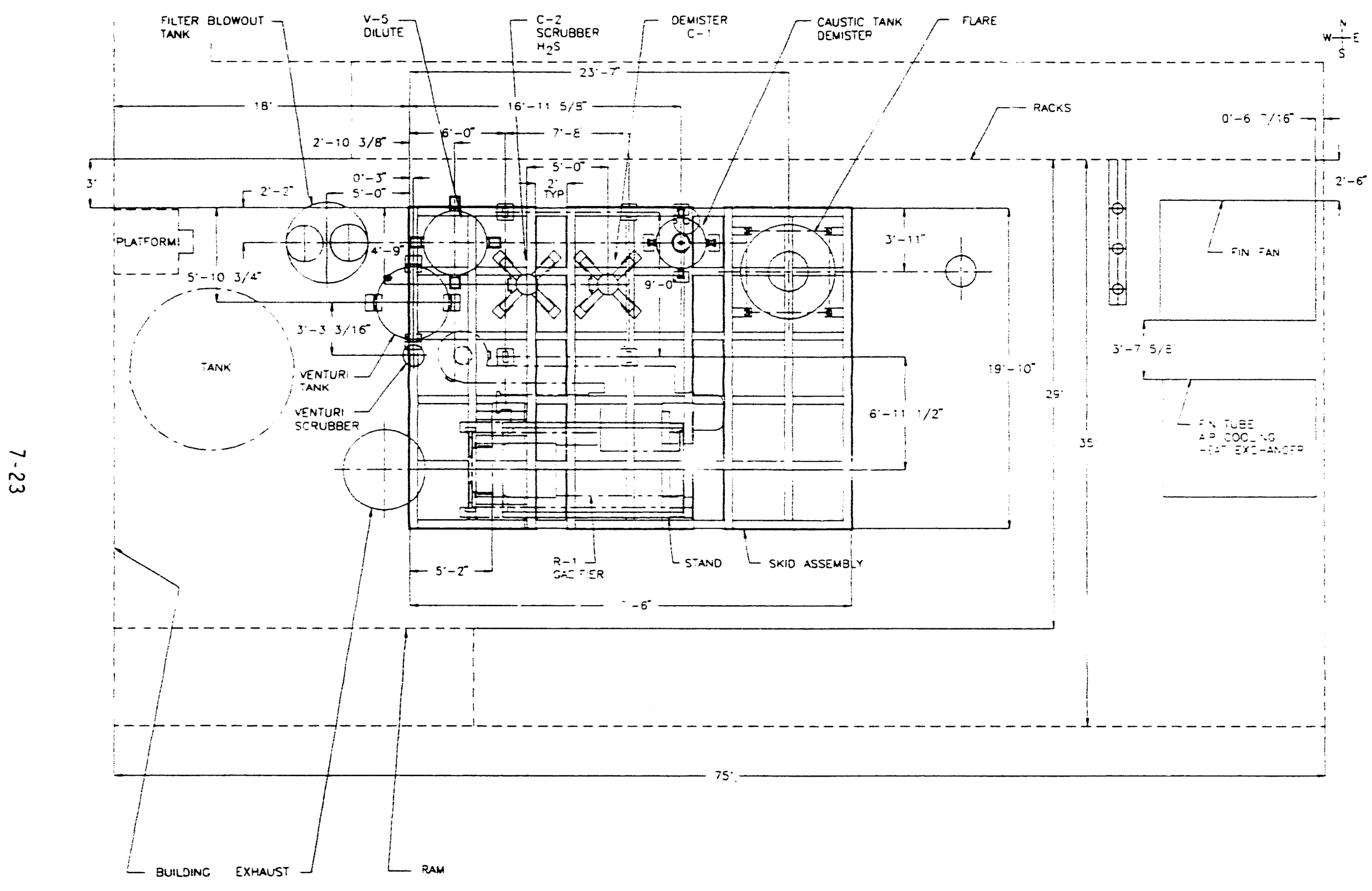

FIGURE 7-8: SCHEMATIC OF PILOT PLANT LAYOUT 


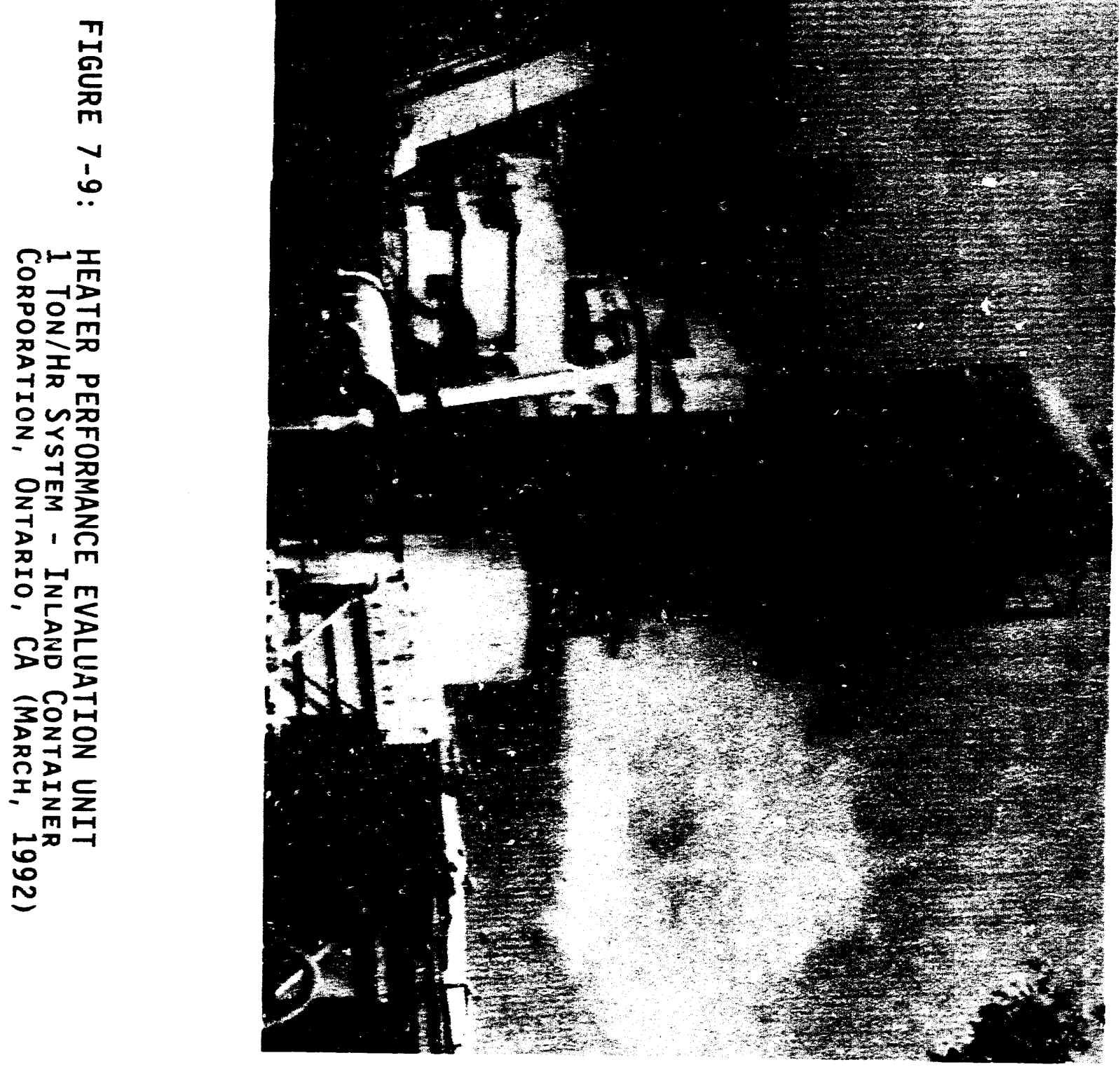




\section{SECTION 8.0 \\ CONCLUSIONS AND RECOMMENDATIONS}

The work accomplished over the past year has resulted in valuable scaleup information with respect to the performance of the heater tube module, system control requirements and system operating parameters. The information gained from the large pilot unit at the Inland Container Corporation's (ICC) Ontario, California recycle paper mill will provide design details and scaleup performance behavior for the core component of the New Bern system, the pulsed heater bundle. This will result in a more effective and less costly installation and field test shakedown period at. New Bern and an acceleration of the commercialization of the gasifier into an early market entry position.

All of the lessons learned at ICC: scale-up design, system and component performance, installation procedures and management, system shakedown testing and, finally, realistic system operating parameters at large scale and in an industrial environment with gasifier plant - paper mill mandatory interfaces and plant ES\&H.

Additional discussions were held with the DOE and Weyerhaeuser to define a field test that would further accelerate the commercialization of the technology. The recommendations proposed by Weyerhaeuser and endorsed by both the DOE and MTCI were based on their experience in selecting, installing and operating new systems or technologies in their paper mills.

The recommended course of action is as follows:

The Process Validation Test should be extended from the original plan of 600 hours to 1000 hours of continuous operation with recycled product gas to be fired in the combustor utilizing the data obtained during the short-term test period, the 1000-hour continuous operational test should be used to evaluate the performance with respect to the New Bern acceptance criteria. These criteria have not yet been finalized but will include specific performance criteria for: 
- Mechanical integrity including corrosion/erosion rates, if test time sufficient to indicate any.

- Steady-state material and energy balances for all stream reduction efficiency.

- Long-term bed fluidization and $p$ : formance characteristics at steady state.

- Conduct familiarization and training classes for New Bern personnel.

- Identify product (process or mechanical modification) improvement with recommendations as to implementation justified.

- Weyerhaeuser decision to assume operation of facility in accordance with defined specific acceptance criteria.

- Finalize operating, safety and maintenance manuals.

A completely new task was Weyerhaeuser's recommendation for a Process Optimization and Long-Term Reliability Test as an absolutely necessary demonstration to complete the project and enter the commercialization market as well as for securing future orders from Weyerhaeuser. Many of the issues to be resolved here speak to the questions asked concerning the maturity of a technology for commercialization. Although the mechanism for providing definitive and factual responses to these questions with the necessary substantiation (data) is technical, the focus is economic and financial.

The long-term, one year of operations by the mill as well as the determination of how much product can be pumped from the reactor (it was designed for two additional heater bundles) is a very important economic factor. The establishment of long-term reliability, maintainability and availability are also very important economic factors involved in commercializing the technology because on-line time is approaching the point where planned maintenance or outages may be scheduled and the long-term effectiveness of product throughput, yield and energy recovery determined. It will also establish the long-term cost of operating the system. 
This is primarily an economic demonstration that should be convincing as to performance in the mill environment by the mill personnel to provide information for purchasers of the Technology.

Some time during the process optimization test period, two additional tube bundles will be fabricated and installed at New Bern to determine the total capacity that can be handled with the gasifier as fabricated for capacity addition. This may require some additional balance of plant, upsizing of original components or adding some extra balance of plant capacity to handle the additional feedstock quantity.

The above activities as recommended by Weyerhaeuser and strongly endorsed by both the DOE and MTCI are seen as essential to providing a convincing demonstration of the maturity of the MTCI technology for near-term commercialization. 


\section{APPENDIX A}

TEST PARAMETERS

A-1 


\begin{tabular}{|c|c|c|c|c|}
\hline & A & B & C & D \\
\hline 1 & DATA & & & \\
\hline 2 & Lead engineer & & & \\
\hline 3 & Data collector & & & \\
\hline 4 & Project number & & & \\
\hline 5 & Feed material & & & \\
\hline 6 & Time & & & \\
\hline 7 & Outside readings & & & \\
\hline 8 & Orifice delta $P$ on the steam to injector screw & & & \\
\hline 9 & Orifice Static $P$ on the steam to injector screw & & & \\
\hline 10 & Steam purge pressure below the knife valve & & & \\
\hline 11 & Steam purge pressure above the knife valve & & & \\
\hline 12 & Sludge bin refill at time: & & & \\
\hline 13 & Load cell reading time: & & & \\
\hline 14 & Load cell reading \#1 & & & \\
\hline 15 & Load cell reading $\# 1$ before refill & & & \\
\hline 16 & Load cell reading \#1 after refill & & & \\
\hline 17 & Load cell reading $\# 2$ & & & \\
\hline 18 & Load cell reading $\# 2$ before refill & & & \\
\hline 19 & Load cell reading \#2 after refill & & & \\
\hline 20 & Load cell reading \#3 & & & \\
\hline 21 & Load cell reading $\# 3$ before refill & & & \\
\hline 22 & Load cell reading \#3 after refill & & & \\
\hline 23 & & & & \\
\hline 24 & & & & \\
\hline 25 & FEED RATE & & & \\
\hline 26 & & & & \\
\hline 27 & PC rotameter gas flowrate & & & \\
\hline 28 & PC gas rotameter pressure & & & \\
\hline 29 & N.G. pressure at inlet to totalizer & & & \\
\hline 30 & N.G. totalizer & & & \\
\hline 31 & at time: & & & \\
\hline 32 & Orifice Delta $P$ for excitation steam & & & \\
\hline 33 & Orifice static pressure excitation steam & & & \\
\hline 34 & Dilution air flow & & & \\
\hline 35 & Dilution air pressure & & & \\
\hline 36 & PC chamber u tube monametre & & & \\
\hline 37 & Air plenum u tube monametre & & & \\
\hline 38 & Date & & & \\
\hline 39 & Time & & & \\
\hline 40 & COMBUSTION AIR DELTAP INCHWC & & & \\
\hline 41 & Natural gas pressure to startup engine & & & \\
\hline 42 & Startup blower engine rpm $\sim 2500 \mathrm{rpm}$ & & & \\
\hline 43 & Start up engine water temp $<160 \mathrm{~F}$ & & & \\
\hline 44 & Fluidization air venturi upstream pressure & & & \\
\hline 46 & Fluidization air venturi delta $\mathrm{P}$ & & & \\
\hline 46 & Inlet temperature to air coolers & & & \\
\hline 47 & AC-2 inlet temperature & & & \\
\hline 48 & AC-1 return temperature & & & \\
\hline 49 & AC-2 return temperature & & & \\
\hline 50 & Sparge header pressure & & & \\
\hline
\end{tabular}




\begin{tabular}{|c|c|c|c|c|}
\hline & A & B & C & $\mathrm{D}$ \\
\hline 51 & PC pilot gas static pressure & & & \\
\hline 52 & Flare pilot static pressure & & & \\
\hline 53 & Demistre column static pressure & & & \\
\hline 54 & H2S scrubber outlet pressure & & & \\
\hline 55 & Bed Delta $P$ & & & \\
\hline 56 & Bed bottom pressure & & & \\
\hline 57 & Bed freeboard pressure & & & \\
\hline 58 & Cyclone recycle eductor orifice delta $P$ & & & \\
\hline 59 & Cyclone recycle eductor orifice static press. & & & \\
\hline 60 & Check the following Pump Outlet Pressures & & & \\
\hline 61 & Venturi Scrubber & & & \\
\hline 62 & H2S Scrubber & & & \\
\hline 63 & Demistre & & & \\
\hline 64 & Filter & & & \\
\hline 65 & Cyclone Delta P & & & \\
\hline 66 & Delta P Filter and filter \# & & & \\
\hline 67 & Tail pipe u tube monametre & & & \\
\hline 68 & Water Main totalizer & & & \\
\hline 69 & at time: & & & \\
\hline 70 & & & & \\
\hline 71 & Date & & & \\
\hline 72 & Time & & & \\
\hline 73 & Boiler water totolizer & & & \\
\hline 74 & at time: & & & \\
\hline 75 & Flash tank totalizer & & & \\
\hline 76 & at time: & & & \\
\hline 77 & Orifice Delta $P$ on the steam purge to bellows & & & \\
\hline 78 & Orifice Static $P$ on the steam purge to bellows & & & \\
\hline 79 & & & & \\
\hline 80 & Check the water level in the following tanks & & & \\
\hline 81 & Waste Heat Boiler & & & \\
\hline 82 & Venturi scrubber tank & & & \\
\hline 83 & Discharge tank & & & \\
\hline 84 & H2S scrubber tank & & & \\
\hline 85 & Demister tank & & & \\
\hline 86 & Weak Caustic tank & & & \\
\hline 87 & & & & \\
\hline 88 & PC flue gas analysis & & & \\
\hline 89 & Oxygen & & & \\
\hline 90 & Co & & & \\
\hline 91 & $\mathrm{CO} 2$ & & & \\
\hline 92 & NOx & & & \\
\hline 93 & $\mathrm{SO2}$ & & & \\
\hline 94 & Hydrocarbon & & & \\
\hline 95 & & & & \\
\hline 96 & Pulse combustion chamber water jacket totalizer & & & \\
\hline 97 & at time: & & & \\
\hline 98 & & & & \\
\hline 99 & & & & \\
\hline 100 & & & & \\
\hline
\end{tabular}




\begin{tabular}{|c|c|c|c|c|}
\hline \multirow{2}{*}{\multicolumn{5}{|c|}{\begin{tabular}{|l|} 
\\
101 \\
\end{tabular}}} \\
\hline & & & & \\
\hline \multicolumn{5}{|l|}{102} \\
\hline \multicolumn{5}{|c|}{103} \\
\hline \multicolumn{5}{|c|}{104 Date } \\
\hline \multicolumn{5}{|c|}{105 Time } \\
\hline \multicolumn{5}{|c|}{106 Inside Control panel readings } \\
\hline \multicolumn{5}{|c|}{107 Shen's computer } \\
\hline \multicolumn{5}{|c|}{108 T1 } \\
\hline \multicolumn{5}{|c|}{109 T2 } \\
\hline \multicolumn{5}{|c|}{110 T3 } \\
\hline \multicolumn{5}{|c|}{\begin{tabular}{|l|l|}
111 & $\mathrm{~T}$ \\
\end{tabular}} \\
\hline \multicolumn{5}{|c|}{112 Average bed temperature } \\
\hline \multicolumn{5}{|c|}{113 Fee board pressure } \\
\hline \multicolumn{5}{|c|}{114 Orifice pressure } \\
\hline \multicolumn{5}{|c|}{115 Orifice temperature } \\
\hline \multicolumn{5}{|c|}{116 Orifice delta $P$} \\
\hline \multicolumn{5}{|c|}{117 Bed density delta $P$} \\
\hline \multicolumn{5}{|c|}{ 118 PC chamber temperature } \\
\hline \multicolumn{5}{|c|}{119 Flare temperature } \\
\hline \multicolumn{5}{|c|}{120 Natural gas orifice delta $P$} \\
\hline \multicolumn{5}{|c|}{ 121 Upstream N.G. pressure SP } \\
\hline 122 & Process gas SP & & & \\
\hline 123 & Process gas delta $P$ & & & \\
\hline 124 & Steam venturi delta $P$ & & & \\
\hline 125 & Steam venturi SP & & & \\
\hline 126 & Fluidization velocity & & & \\
\hline 127 & Steam FCV controller output & & & \\
\hline 128 & Cyclone steam jacket orifice delta $P$ & & & \\
\hline 129 & Tail pipe static pressure & & & \\
\hline 130 & PC static pressure & & & \\
\hline 131 & Air plenum static pressure & & & \\
\hline 132 & Combustion air FCV output & & & \\
\hline 133 & Eied temperature, E\&W of reactor & & & \\
\hline 134 & Natural Gas FCV opening & & & \\
\hline 135 & Date & & & \\
\hline 136 & Time & & & \\
\hline 137 & Bed delta $P$ & & & \\
\hline 138 & Bed bottom static pressure & & & \\
\hline 139 & Boiler pressure & & & \\
\hline 140 & Boiler valve opening & & & \\
\hline 141 & Average mid bed temperature & & & \\
\hline 142 & Metering bin speed & & & \\
\hline 143 & TC switch with 40 position & & & \\
\hline 144 & T1 - air plenum & & & \\
\hline 145 & T2 - free board combustor side & & & \\
\hline 146 & 73- free board exhaust side & & & \\
\hline 147 & T4 - stack exit, WHE $<<400$ deg $F$ if not check level & & & \\
\hline 148 & T5-VS exit & & & \\
\hline 149 & T6- cycione exit / VS entrance & & & \\
\hline 150 & T7-Demistre exit & & & \\
\hline
\end{tabular}




\begin{tabular}{|c|c|c|c|c|}
\hline & A & B & C & D \\
\hline 151 & T8 - inlet to cyclone return eductor & & & \\
\hline 152 & T9- Venturi scrubber splash tank & & & \\
\hline 153 & T10-Flash tank & & & \\
\hline 154 & T11-Flash tank outlet to flare & & & \\
\hline 155 & T12-Superheater inlet & & & \\
\hline 156 & T13-Superheater outlet @ sparge tube header & & & \\
\hline 157 & T14 - Sat. steam entrance to Cyclone after PRV & & & \\
\hline 158 & T15-Combustor refractory temperature & & & \\
\hline 159 & T16 - Bed backwall by tail pipe & & & \\
\hline 160 & $T 17-P C$ jacket water oulet & & & \\
\hline 161 & $T 18$ - Bed over just above sparge (midway) & & & \\
\hline 162 & T19 - Bed over sparge (midway) & & & \\
\hline 163 & T20- Not in use & & & \\
\hline 164 & T21 - Not in use & & & \\
\hline 165 & T22-PC jacket water inlet & & & \\
\hline 166 & T23 - N.G. orifice (main gas) & & & \\
\hline 167 & T24 - Superheated steam orifice (fluidization) & & & \\
\hline 168 & Date & & & \\
\hline 169 & Time & & & \\
\hline 170 & T25-Ariflow & & & \\
\hline 171 & T26 - PC exit water jacket after belows & & & \\
\hline 172 & T27 - Steam cyclone orifice & & & \\
\hline 173 & T28-Product gas superheater exit & & & \\
\hline 174 & T29 - Process gas cyclone inlet & & & \\
\hline 175 & T30 - Prcoess gas orifice & & & \\
\hline 176 & T31 - Cyclone steam jacket exit & & & \\
\hline 177 & T32 - Flue gas at PC exit, before boiler & & & \\
\hline 178 & T33 - Heat flux probe $\# 1$, far side & & & \\
\hline 179 & T34 - Heat flux probe $\# 2$, far side & & & \\
\hline 180 & $T 35-$ Heat flux probe $\# 3$, near side & & & \\
\hline 181 & T36- steam temp on cyclone recycling eductor & & & \\
\hline 182 & & & & \\
\hline 183 & & & & \\
\hline 184 & & & & \\
\hline 185 & & & & \\
\hline 186 & TC Switch with 20 position & & & \\
\hline 187 & TT1- Tube surface temp, top tube, 5 " from PC & & & \\
\hline 188 & TT2- Tube surface temp, top tube, 12" away & & & \\
\hline 189 & TT3-Tube surface temp, top tube, $33^{\prime \prime}$ away & & & \\
\hline 190 & TT4-Tube surface temp, top tube, 67 " away & & & \\
\hline 191 & TT5-Tube surface temp, top tube, 106" away & & & \\
\hline 192 & TT6- Tube surface temp, far side, 5 " from PC & & & \\
\hline 193 & TT7-Tube surface temp, far side, 12" away & & & \\
\hline 194 & TT8-Tube surface temp, near side, 5 " from PC & & & \\
\hline 195 & TT9-Tube surface temp, near side, 12" away & & & \\
\hline 196 & $\pi$ 10-Bed temp,far side, $P C$ side, $2^{\prime \prime}$ below top tube & & & \\
\hline 197 & TT11-Bed temp,far side, 12 " from heat flux 1 & & & \\
\hline 198. & TT12-Bed temp, far side, middle, 4" above top tube & & & \\
\hline 199 & TT13-Bed temp, far side, TP end, 8 " below top tube & & & \\
\hline 200 & TT14-Bed temp,near side, $\mathrm{PC}$ side, $2^{2}$ below top tube & & & \\
\hline
\end{tabular}




\begin{tabular}{|c|c|c|c|c|}
\hline & A & B & C & D \\
\hline 201 & Date & & & \\
\hline 202 & Time & & & \\
\hline 203 & TT15-Bed temp, near side, $3^{\prime \prime}$ from heat flux 3 & & & \\
\hline 204 & TT16-Bed temp, near side, middle, 8 " below top tube & & & \\
\hline 205 & TT17- Bed temp, bottom, 11" away from PC end & & & \\
\hline 206 & TT18-Bed temp, bottom, 39" away from PC end & & & \\
\hline 207 & TT19-Bed temp, bottom, 86" away from PC end & & & \\
\hline 208 & TT20-Bed temp, bottom, 108" away from PC end & & & \\
\hline 209 & & & & \\
\hline 210 & & & & \\
\hline 211 & Pulse combustor peak to peak setting & & & \\
\hline 212 & Pulse combustor peak to peak division & & & \\
\hline 213 & Pulse combustor amplitutde & & & \\
\hline 214 & Pulse combustor frequency & & & \\
\hline 215 & & & & \\
\hline 216 & Check the following alarm light mark ON/OFF & & & \\
\hline 217 & Boiler water level lo-lo & & & \\
\hline 218 & Boiler pressure low & & & \\
\hline 219 & Venturi scrubber pump failure & & & \\
\hline 220 & Density meter low level & & & \\
\hline 221 & Delta $P$ for bed low level & & & \\
\hline 222 & Flare temperature low & & & \\
\hline 223 & & & & \\
\hline 224 & & & & \\
\hline 225 & & & & \\
\hline 226 & & & & \\
\hline
\end{tabular}



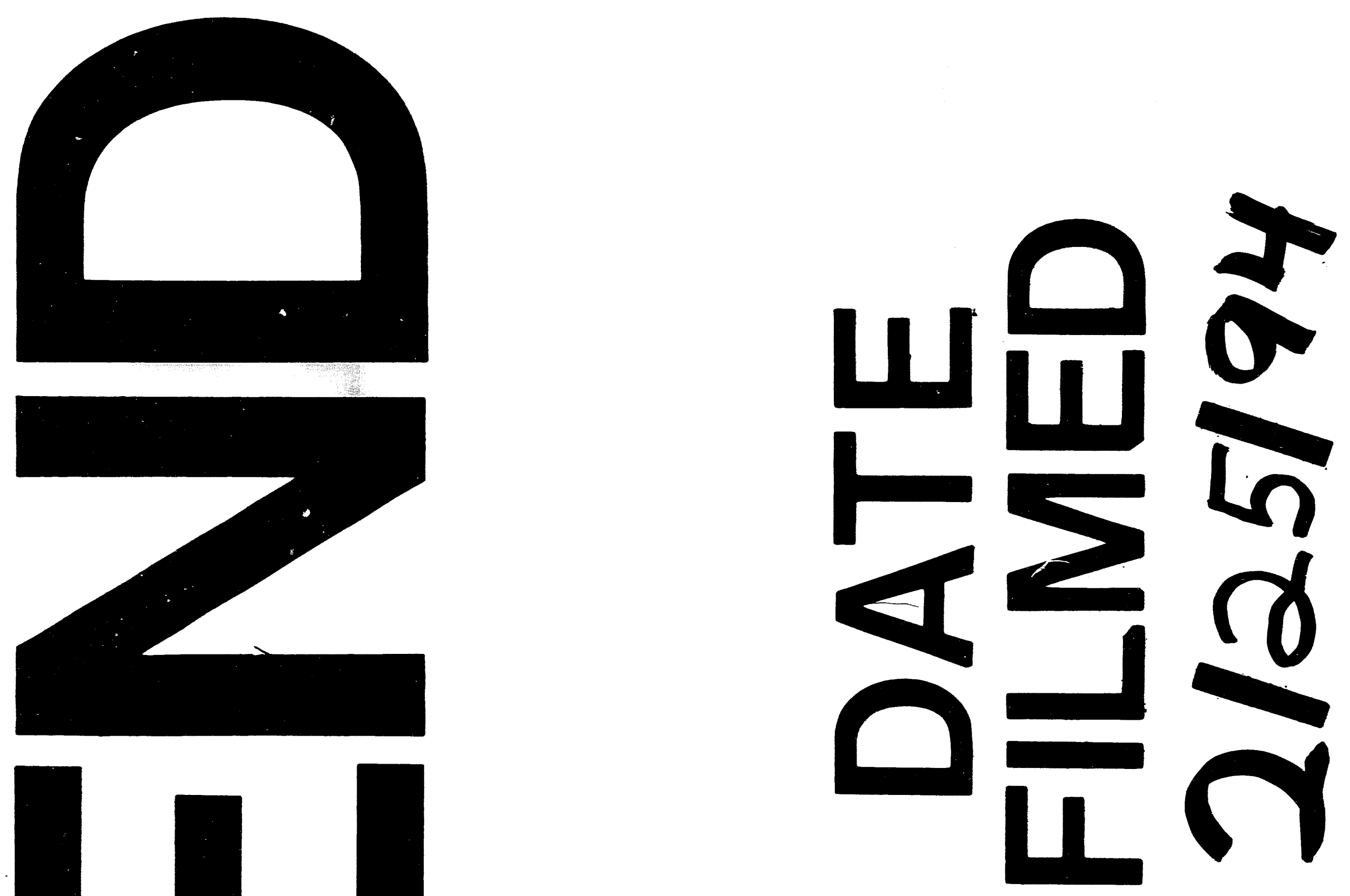

1

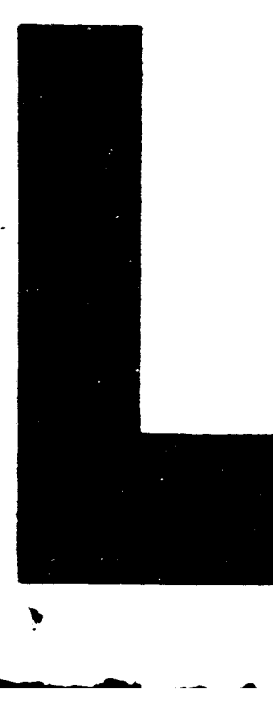

$-$ 
$\mid$ 